\title{
NO STOCK DoEfPLPS9548984
}

PHASE 2, AUTOMATED ARRAY ASSEMBLY, TASK IV LOW-COST SOLAR ARRAY PROJECT

Final Report

October 1978

Work Performed Under Contract No. NAS-7-100-954898

Lockheed Missiles \& Space Company, Inc.

Sunnyvale, California
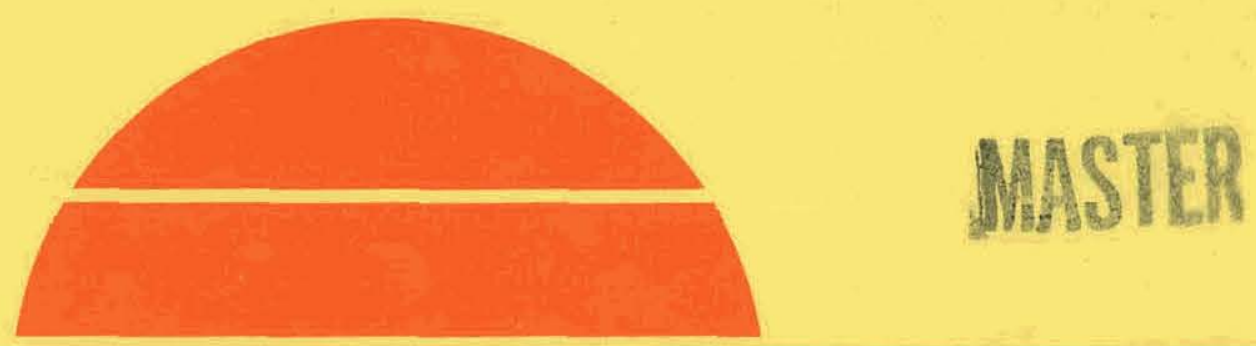

\section{U.S. Department of Energy}

Dismititit: 


\section{DISCLAIMER}

This report was prepared as an account of work sponsored by an agency of the United States Government. Neither the United States Government nor any agency Thereof, nor any of their employees, makes any warranty, express or implied, or assumes any legal liability or responsibility for the accuracy, completeness, or usefulness of any information, apparatus, product, or process disclosed, or represents that its use would not infringe privately owned rights. Reference herein to any specific commercial product, process, or service by trade name, trademark, manufacturer, or otherwise does not necessarily constitute or imply its endorsement, recommendation, or favoring by the United States Government or any agency thereof. The views and opinions of authors expressed herein do not necessarily state or reflect those of the United States Government or any agency thereof. 


\section{DISCLAIMER}

Portions of this document may be illegible in electronic image products. Images are produced from the best available original document. 


\section{NOTICE}

This report was prepared as an account of work sponsored by the United States Government. Neither the United States nor the United States Department of Energy, nor any of their employees, nor any of their contractors, subcontractors, or their employees, makes any warranty, express or implied, or assumes any legal liability or responsibility for the accuracy, completeness or usefulness of any information, apparatus, product or process disclosed, or represents that its use would not infringe privately owned rights.

This report has been reproduced directly from the best available copy.

Available from the National Technical Information Service, U. S. Department of Commerce, Springfield, Virginia 22161.

Price: Paper Copy $\$ 6.50$

Microfiche $\$ 3.00$ 


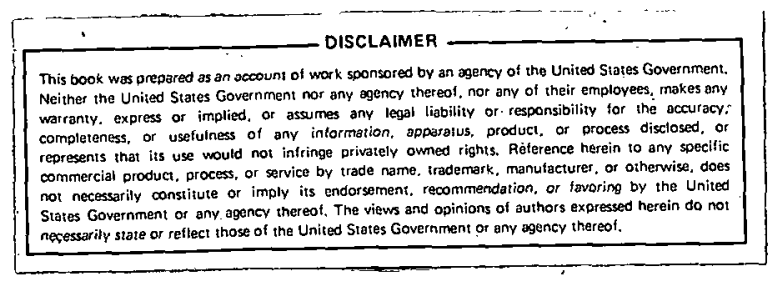

PHASE 2, AUTOMATED ARRAY ASSEMBLY, TASK IV LOW-COST SOLAR ARRAY PROJECT

FINAL REPORT

OCTOBER 1978

Prepared By

LOCKHEED MISSILES \& SPACE COMPANY, INC. 1111 Lockheed Way Sunnyvale, CA 94086

The JPL Low-Cost Silicon Solar Array Project is sponsored by the U.S. Department of Energy and forms part of the Solar Photovoltaic Conversion Program to initiate a major effort toward the development of low-cost solar arrays. This work was performed for the Jet Propulsion Laboratory California Institue of Technology by agreement between NASA and DoE.

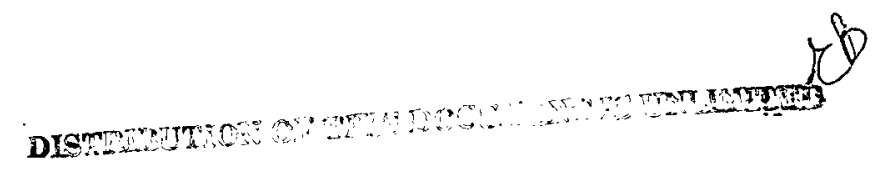


FOREWORD

The results described herein represent the work performed from November 1 , 1977 to October 28, 1978 by the Manufacturing Research Organization of Lockheed Missiles \& Space Company, Inc. in Sunnyvale, California. The project team, headed by Mike Lopez, was staffed with the following key personne 1:

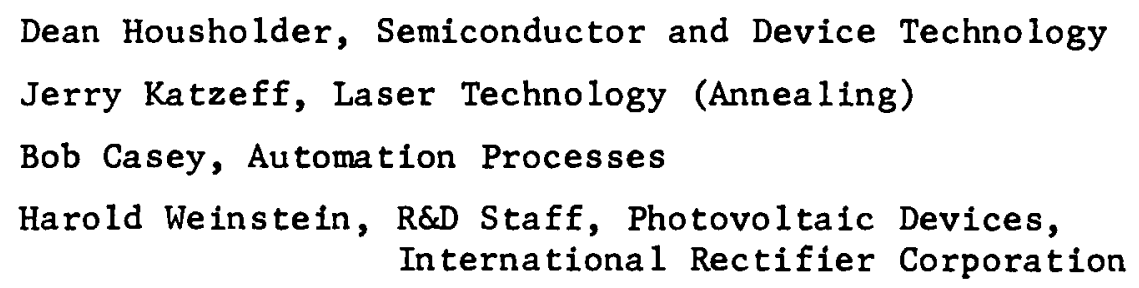

Other principal contributors included John Knudson, Ion Implantation; and Cheryl Bostwick, Screen Printing of Contacts.

The JPL Contract Technical Manager was B. D. Gallagher. 
TABLE OF CONTENTS

Section

Page

FOREWORD

iii

TABLE OF CONTEN'TS

iv

LIST OF TABLES

vi

LIST OF ILLUSTRATIONS

vii

1

SUMMARY

1

INTRODUCTION

4

TECHNICAL DISCUSSION

6

3.1 TECHNICAL AND ECONOMIC EVALUATION

3.1.1 Texture Etch

3.1.2 Ion Implantation

3.1.3 Laser Anneal

3.1.4 Screen Printed Contacts

3.1.5 Spray-On AR Coatings

3.2 CRITICAL REVIEWS

3.2.1 Texture Etching

3.2.2 Ion Implant

3.2.3 Laser Anneal

3.2.4 Screen Printing

3.2.5 Spray-On AR Coatings

3.3 PROCESS VERIFICATION

3.3.1 Texture Etching

3.3.2 Ion Implantation

3.3.3 Laser Annealing

26

3.3.4 Screen Printed Contacts

45

3.3.5 Spray-On AR Coating

3.4 HIGH VOLUME PRODUCTION PLAN 
TABLE OF CONTENTS (Continued)

$\underline{\text { Section }}$

3.5 PROCESS PROCEDURES

62

3.6 SAMICS

63

CONCLUSIONS

64

5 RECOMENDATIONS

66

RE FERENCES

67

\section{APPENDIX}

\section{LIST OF TABLES}

Table

Page

1 Wafer Implantation Parameters

24

2 Summary of Laser Annealing Work

33

3

Spun-On Ta Solutions

56

4

Spray-On Ta Solutions

56

5

Spray-On Ta Solution Electrical Output Effects Before and After 

of Wavelength

6 SEM photos $\left(2000 \times / 60^{\circ}\right.$ TIIt) of the Surface of a Texture-Etched/Ion Implanted S111con Wafer before (A) and after Laser Annealing (B)

9 I-V Curve for a 3-inch Dlameter Solar Cell Annealed with a Quantronix Nd:YAG Laser Scriber Nd:YAG Laser Scriber

11 I-V Curve for a $2 \times 4 \mathrm{~cm}$ Cell Annealed with a Quantronix Nd:YAG Laser Scriber

12 I-V Curve for a $1 \times 2 \mathrm{~cm}$ Cell Annealed with a Quantronix Nd:YAG Laser Scriber

13 I-V Curve for a $1 \times 1.9 \mathrm{~cm}$ Cell Annealed with an ESI/ Holobeam Nd:YAG Laser Scriber

14 Profiles of the Distribution of Phosphorus Atoms in a Polished Silicon Wafer

15 Profiles of the Distribution of Phosphorus Atoms in a Flash-Etched Silicon Wafer 


\section{L.IST OF ILLUSTRATIONS (Continued)}

Figure

$\underline{\text { Page }}$

17 A Typical Belt Furnace Firing Profile Used for Owens Illinois 6105/6109 Silver Pastes

18 Zicon 10,000 Autocoater - Spray Module

Transmittance $8 \mathrm{mil}$ Thick Plain Glass

51

20

Transmittance $\# 201$ Coating/Baked $175^{\circ} \mathrm{C}$

52

21 Reflectance \#201 Coating/Baked $175^{\circ} \mathrm{C}$

53

22 Reflectance 非201 Coated Cell vs. Uncoated 
Section 1

SUMMARY

This contract was to verify the technological readiness of a select process sequence with respect to satisfying the Low Cost Solar Array Project objectives of meeting the designated goals of $\$ .50$ per peak watt in 1986 (1975 dollars). The sequence examined consisted of: 3 " diameter "as-sawn" Czochralski grown 1:0:0 silicon, texture etching, ion implanting, laser annealing, screen printing of ohmic contacts and sprayed anti-reflective coatings. The contract was a one (1) year effort.

The texture-etching process as furnished by JPL was exercised using the sodium hydroxide $(\mathrm{NaOH})$ solution on representative "as-sawn" wafers. The initial "flash-etch" step consisting of a solution of nitric, hydrofluoric and acetic acids to remove saw damage from the silicon surfaces prior to the texture-etch step was eliminated, thereby simplifying the process. A $1 \%-2 \%$ solution of $\mathrm{NaOH}$ followed by a neutralizing step of hydrogen peroxide-sulfuric acid solution resulted in acceptably etched wafers. Texture-etched wafers processed into functional cells were comparable in electrical output $(\eta=10 \%$ AMI) to those flash etched. Both types were electroless nickel plated, solder dipped and $A R$ coated by vacuum evaporation.

Ion implantation evaluations for junction formation with phosphorus was performed with a Lockheed Acceleration, Inc. Model MP400 unit and an International Rectifier Extrion Model 20-200 unit. The Extrion 20-200 implanter proved best suited for the solar cell junction formation due principally to the lower acceleration voltage levels necessary for shallow junction devices. For our work, wafers were implanted at the lowest practical level of $25 \mathrm{KeV}$, with a beam current of $150 \mu \mathrm{A}$, and at a $7^{\circ}$ tilt angle to minimize channeling. Best cell results were attained at the 2.5 to $3 \times 10^{15}$ ions $/ \mathrm{cm}^{2}$ fluence levels. Acceleration voltage levels of 5 to $10 \mathrm{KeV}$ are more desirable for shallow junction solar cells and will also minimize the bucking drift field created near the immediate silicon surface during implantation due to the Gaussian 
ion distribution. It is felt that this bucking field can be eliminated through the use of a programed implant cycle, where the acceleration voltage can be automatically varied with time, holding the beam current constant.

Cells implanted and thermally annealed compared favorably in electrical output with diffused junction cells, and were used as controls for the evaluation of the subsequent laser annealing step.

Laser annealing work consisted of experimentation with various available lasers using implanted wafers. With the absorption coefficient of silicon as the guiding criteria, it was decided that the most suitable lasers for silicon annealing are ruby, Nd:YAG or Frequency Doubled Nd:YAG with wavelengths of $694 \mathrm{~nm}, 1064 \mathrm{~nm}$, and $532 \mathrm{~nm}$, respectively. Extent of annealing was determined by measurements made with a 4-point probe. Impurity profiling, as implanted and after annealing, was performed by Secondary Ion Mass Spectrometry (SIMS). Energy densities on the order of 1.5 joules $/ \mathrm{cm}^{2}$ were found necessary to achieve annealing using a ruby laser; whereas, with the Nd:YAG lasers used for this work, energy densities of $>2$ joules $/ \mathrm{cm}^{2}$ were required.

Approximately forty (40) cells, $1 \times 2 \mathrm{~cm}, 2 \times 4 \mathrm{~cm}$ and 3 inches diameter, were fabricated at the conclusion of this program, which were ion implanted, $\mathrm{Nd}$ :YAG laser annealed, vacuum evaporated $\mathrm{Ti} / \mathrm{Pd} / \mathrm{Ag}$ contacts and evaporated $\mathrm{SiO}_{2}$ AR coating. These cells yielded AMl conversion efficiencies ranging from 10.1 to $13.3 \%$ with an average of $12.3 \%$. This represents a significant step towards reduction-to-practice of a potentially high volume, low cost process, and warrants continuation for scale-up.

Screen printing of ohmic contacts did not prove entirely successful during the course of this contract. Using some generally accepted silver and silveraluminum pastes, namely, DuPont 7095 and 7095+ Alcoa aluminum powder 7123, and a 325 mesh stainless steel screen, difficulty was experienced in the firing schedule which were manifested in poor cell curve functions. Also highlighted in our work, was the high cost of conductive paste materials, 
which appears questionable towards meeting the LSA cost goals. This screen printing work was not pursued further due to the extensive investigations by other participants in this PROJECT.

Sprayed-on AR coating evaluations were conducted with a vapor carrier autocoater system. Best thickness uniformity of $1100 \AA$ to $1240 \AA$ was attained on a 3/4" width pattern with a single spray pass. Multiple passes and work index-. ing was required for a 3 -inch diameter cell. Improved nozzle and vapor spreader design and precision fabrication are required for optimized performance of this equipment. A tantalum solution sprayed on 3 -inch texture-etched cells yielded a $7 \%$ electrical output increase which appears consistent with published literature on AR-coated textured surfaces.

High volume production projections were made on the selected process sequence. Automated processing and movement of hardware at high rates were conceptualized to satisfy the PROJECT's $500 \mathrm{MW} / \mathrm{yr}$ capability. A production plan was formulated with flow diagrams integrating the various processes in our cell fabrication sequence. 
Section 2

INTRODUCTION

This contract was a process development effort to verify the technological readiness of a selected process sequence from the "as-sawn" Czochralski grown silicon wafers to the module assembly.

The process investigated consisted of the following sequence:

- Starting material: 3-inch "as-sawn" C2 silicon wafers

- Texture etching of silicon wafers using sodium hydroxide

- Junction formation by ion implantation of phosphorus

- Laser annealing of ion implanted wafers

- Screen printing of $\mathrm{Ag}, \mathrm{Ag}-\mathrm{Al}$ for ohmic contact

- Spraying of Tantalum oxide AR coating

- Assembly of modules using the LMSC module design, developed under the JPL Contract 954653, as baseline

This selected process sequence was evaluated for its technical potential of achieving the economic goals of the Low Cost Solar Array Project of $\$ .50 /$ watt for 500 megawatt/year production by 1986 .

Specific areas of investigation under this contract consisted of the following :

- Performance of detailed technical and economic evaluations of the selected process sequence

- Preparation of process step descriptions detailing input-output requirements and characteristics, and identifying materials, supplies and equipment utilized 
- Performance of critical reviews to identify processing areas which require significant development, or proof of operation to reach the PROJECT goals

- Performance of process verifications of the selected sequence

- Demonstration of the technological readiness of the selected process by fabrication of cells

Solar cells were fabricated and evaluated for their respective efficiencies and throughput. The SAMICS format was utilized for inputs in the determination of economic considerations.

International Rectifier, E1 Segundo, California worked jointly with us to satisfy the various facets of the contract.

Two process steps of the specified sequence received greater emphasis in this contract. These were: laser annealing and sprayed AR coating. Laser annealing offers the potential of reduced energy consumption and improved efficiency at no loss in throughput over conventionally practiced techniques; Automated spray coating of anti-reflective film has the potential of improved thickness control and uniformity over large surface areas. The balance of the steps in the cell processing sequence were performed only to provide a supply of wafers with which to exercise the laser anneal and spray coating work. These were considered routine and were studied in greater detail by other contractors.

At the outset, fabricated cells using our process sequence were to be assembled into the Lockheed-designed module configuration. The effort was later redirected resulting in deletion of the module work so that resources could be more effectively applied to the main stream of cell processing. 
Section 3

TECHNICAL DISCUSSION

\subsection{TECHNICAL AND ECONOMIC EVALUATION}

A detailed evaluation of our selected process sequence was conducted and reported in the quarterly reports. The sequence consisted of: texture etching, ion implanting, laser annealing, screen printing ohmic contacts and spray-on AR coating. Our analyses of the Individual process steps are summarized in the following paragraphs.

\subsubsection{Texture Etch}

There is general agreement among the LSA contractors that texture etching is a viable process for use on $\langle 1: 0: 0\rangle$ single crystal silicon. The low cost potential compared with the standard polished surfaces, makes texture etching highly attractive for attaining low reflectance surfaces. The need for decreased surface reflectance is well documented in the 11 terature and through work performed by other JPL/DOE contractors on this LSA PROJECT.

High volume, high throughput potential to satisfy the 500 MN capability is attainable. A high volume production processing concept was identified which utilizes cassettes containing 50 cells, moving via conveyors through the various solutions at a rate of 2 feet/minute. Estimated output rates from such a system are on the order of 200 wafers/minute, which are of sufficient magnitude for the high volume PROJECT goal. The flash etch step using nitric ( $\mathrm{HNO}_{3}$ )/hydrofluoric (HF)/acetic $\left(\mathrm{CH}_{3} \mathrm{OOH}\right.$ ) acid solutions for saw damage removal was eliminated without any apparent deleterious effects on the performance of the cells. Likewise, it is believed the post texturizing hydrogen peroxide step can be replaced by a fully integrated in-line force flush water spray system. This would eliminate the use of environmentally undesirable chemicals, simplifying the process and lowering costs. 
There is some question on the compatibility of textured surfaces with laser annealing, one of our selected process steps. Work performed to date with laser annealing points to the necessity for surface melting in order to obtain proper electrical activation. Thus, the topography of the surface is changed from sharp pyramidal structures to "rolling hill" contours. The effects of melting on the cell junction are discussed in the process verification section under laser annealing.

There is further concern that texture etching increases handing damage, complicating the processing and can lead to lower cell yields. This is caused by the fragile nature of the pyramidal points formed and their susceptibility to breaking, which can then expose the junction.

An alternate to the "wet" chemical texture etching process is plasma etching, where substantial savings can be realized through the elimination of expensive chemicals, and subsequent chemical disposal cost. Also, only one side etching may be performed, thereby saving silicon material losses. Throughput rates, however, need to be improved in order to make this process viable. It is our opinion that plasma etching should be scrutinized more closely as a potential replacement for the wet chemical texturizing process for solar cells.

\subsubsection{Ion Implantation}

General acceptance of ion implantation for junction formation is primarily based on the high throughput potential. Other significant attributes consist. of better control of the doping quality and quantity, and doping profile. These are characteristics essential to insure cell uniformity, quality and repeatability.

The primary disadvantage currently encountered during implantation is the formation of an essentlally amorphous surface layer due to impurity ion collisions with the single crystal silicon lattice. Present means for restoring 
crystallinity in the surface layer and activating the impurity ions is by thermal annealing in a furnace at $900^{\circ}$ to $1000^{\circ} \mathrm{C}$ for 15 to 45 minutes.

Although this technique restores the crystal structure to an acceptable level, it also causes excessive impurity diffusion and introduces bulk dislocation loops in the subsurface silicon due to the high temperature thermal cycling. This causes trapping centers which reduces cell efficiency. This is true to a certain degree for any doping technique requiring a thermal diffusion or redistribution of the desired impurity. Laser annealing obviates this thermal cycle of the bulk silicon by heating only the surface layer, thus, leaving the bulk silicon essentially free of thermally induced dislocation loops.

The automation potential of ion implanting is very high, being limited by mechanical cell handling and the ability to cool cells during implant. New implanters are available from Extrion and Lintott with $2 \times 10^{-3} \mathrm{~A}$ and $4 \times 10^{-3} \mathrm{~A}$ beam currents, respectively, lowering implant time per cell to seconds. As an example, calculations based on a present Extrion 20-200 system with a $50 \mu$ a beam current result in an implant time of 209 seconds. This compares with soon to be available dedicated $10 \mathrm{ma}$ beam current systems which can reduce the time to 1 second. With the short implant time, the major obstacle to achieve high throughput lies in the cell handling.

In view of the potentially short implant time, a high volume, high throughput process was conceptualized during the course of this contract (reported in Quarterly Report No. 3) which reflects the 1 wafer/second rate of a 10 ma beam current system. This concept addresses the movement and handing of cells at a rapid rate, and is summarized in Section 3.4, High Volume Production Plan. A production rate of 3000 wafers/hour is projected per implanter.

\subsubsection{Laser Annea 1}

Based on the published literature ${ }^{1-4}$, laser annealing offers several technical advantages over the presently utilized furnace annealing technique. The advantages are: 
1. Reduction by one to two orders of magnitude of the bulk silicon dislocations introduced by present furnace anneal techniques

2. Increase in the minority carrier lifetime in the implanted layer and in the underlying substrate material

3. Change of the implanted concentration profile from an undesired Gaussian distribution to a broader, nearly flat top distribution This improves solar cell performance by eliminating the undesired bucking drift field produced by the Gaussian distribution, hence increasing the collection efficiency of the cell.

4. More complete regrowth of the implanted surface resulting in fewer dislocation loops and stacking faults due to the higher temperature achieved with pulsed laser annealing in comparison to what is a practical temperature with furnace annealing

5. Precision control of annealing depth by choice of laser type can be accomplished since most of the energy expended will be dissipated near the silicon surface and will depend on the wavelength of the particular laser chosen and its absorption coefficlent in silicon

The guiding criteria in selecting a laser system for solar cell annealing falls into three categories which are as follows:

1. The laser must be capable of providing sufficient power and energy to allow the required annealing process to take place.

2. The laser must be of a suitable wavelength to minimize the depth of beam penetration in to the silicon.

3. The laser must be capable of annealing the cells at energies and speeds which would make the system cost compatible with the PROJECT objectives.

Since the light absorption coefficient, Figure 1, of silicon and consequently the mean absorption length increase considerably with increase in the wave- 


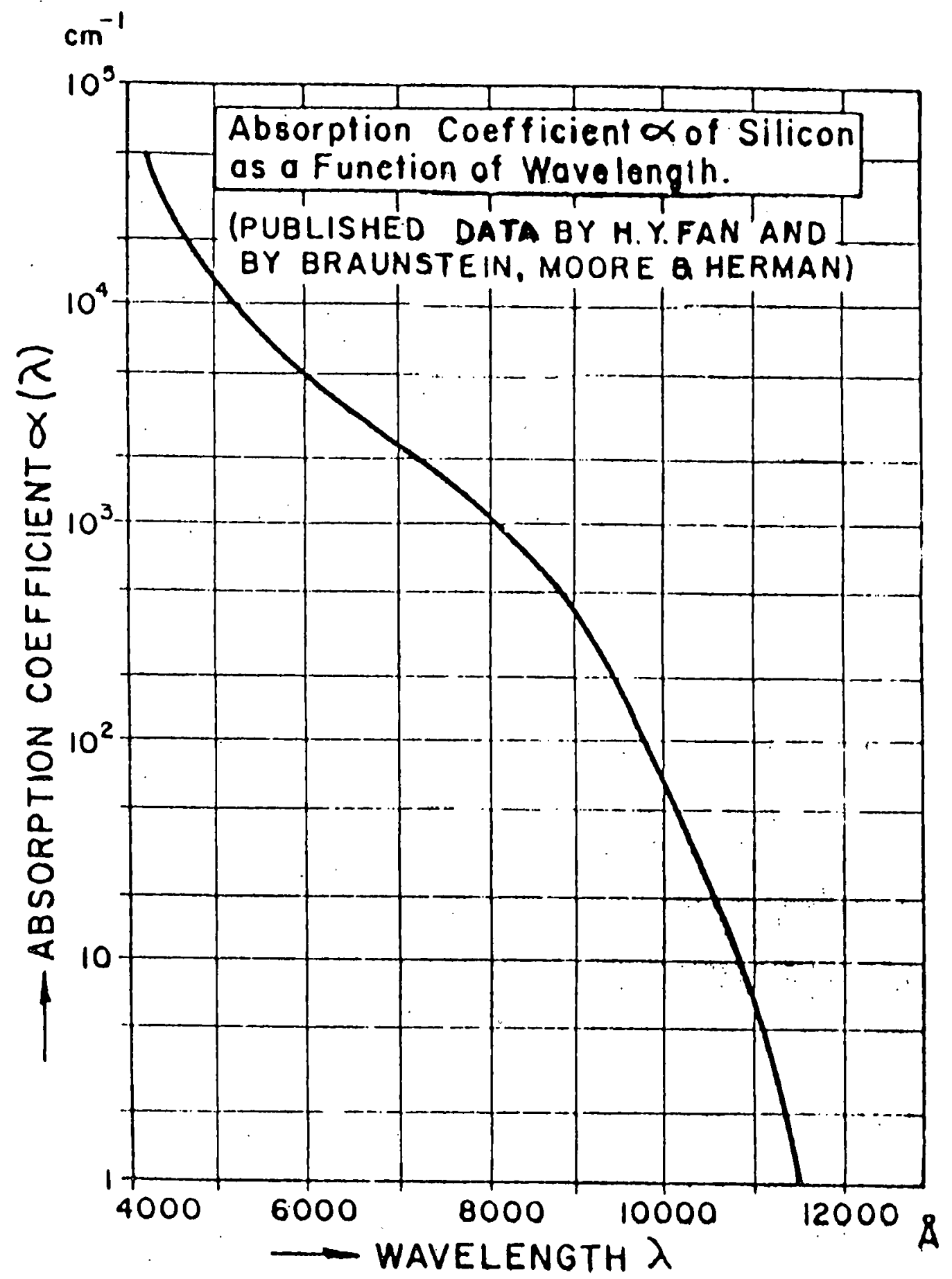

Figure 1. Absorption Coefficient $\alpha$ of Silicon as a Function of Wavelength 
length of the incident beam, it was concluded that no laser exceeding the wavelength of a YAG laser need be considered. The three lasers which appeared to be the best candidates for this evaluation were ruby, Nd:YAG, and Nd:YAG/ SHG (a Nd:YAG laser coupled to a second harmonic generator, or as it is also called, a frequency doubler). These lasers have wavelengths of $694 \mathrm{~nm}, 1064 \mathrm{~nm}$, and $532 \mathrm{~nm}$, respectively. Based on the high throughput projection requirements for the LSA PROJECT, only pulsed laser systems were considered.

Transitions from amorphous to single crystal layers with pulse annealing are due to the formation of a liquid-solid system during laser irradiation.

It has been reported by other researchers ${ }^{1,5)}$ that annealing of the implant damage and electrical activation of the implanted ions can be achieved with a continuous wave (CW) argon laser $(\lambda=488 \mathrm{~nm})$ through a solid-solid reaction. To obtain a solid-solid reaction, the surface to be annealed is maintained below its melting point. The duration that a surface point requires for annealing is in the order of several milliseconds. This time span in relation to incident energy is apparently long enough to anneal the implant damage and electrically activate the implanted ions but is too short for profile changes to occur.

On the first glance, it may appear that for a wavelength dependent process, CW annealing offers the advantages of creating shallow junctions by annealing and activating the surface while maintaining the relative immobility of the junction. It is our feeling, however, that extremely shallow junctions for solar cell applications can be attained through low level implants $5 \mathrm{KeV}$ followed by annealing with a frequency doubled Nd:YAG or Nd:Glass laser at $\lambda=532 \mathrm{~nm}$. Annealing with the frequency doubled laser should not only yield shallow junctions but will also change the implanted concentration profile from an undesired Gaussian distribution (unaltered after CW annealing) to a broader, nearly flat top distribution. This Improves solar cell performance by eliminating the undesired bucking drift field produced by the Gaussian distribution, hence increasing the collection efficiency of the cell. 
By utilizing pulse annealing, it appears that throughputs on the order of one 3-inch diameter wafer per second can be attained. Argon lasers on the other hand are of fairly low power requiring time spans on the order of minutes for annealing a 3-inch diameter wafer. The input power requirements of such a system would be prohibitive as well as the impracticality of the process in view of the high throughput requirements of the PROJECT, namely $500 \mathrm{MW} /$ year fabrication capability.

Theoretical and experimental work carried out on the pulsed lasers revealed that for ruby and Nd:YAG/SHG lasers with pulse duration in the 10-30 nsec range, an energy density of approximately 1.5 joules $/ \mathrm{cm}^{2}$ is needed to attain the required annealing. This translates to approximately 68 joules for single pulse annealing of a 3-inch diameter wafer. Energy densities necessary vary with the pulse duration and wavelength. For example, investigations have shown that a Nd:YAG (1064 nm) laser with a $100 \mathrm{nsec}$ pulse requires an energy density output of approximately 4.8 joules $/ \mathrm{cm}^{2}$ to effect proper annealing. A Nd:YAG laser with a longer wavelength and pulse duration is not as efficient as a ruby $(694 \mathrm{~nm})$ or frequency doubled YAG $(532 \mathrm{~nm})$ laser due to deep penetration into the silicon. Deeper penetration means greater energy losses in the bulk material rather than at the immediate surface $(\approx .2 \mu \mathrm{m})$, where it is required for proper annealing.

Laser annealing is conducive to high throughput manufacturing. Performed in an air atmosphere, a 3-inch diameter single pulse system is projected for the LSA PROJECT high volume capability. With a pulse duration of less than 50 nanoseconds, laser repetition rate, and wafer positioning and handling become the most important elements for achieving high throughputs. High energy demands and high repetition rates ( 1 pulse per second) can be satisfied with a laser that utilizes phosphate glass for its laser rod material. Rapid positioning and handling of wafers are addressed in a concept detailed in Quarterly Report No. 3, and summirized in Section 3.4, High Volume Production Plan, where quantitles of 3600 wafers/hour/laser can be processed.

An economic evaluation was made showing the potential savings of laser vs. furnace annealing. This analysis was also reported in Quarterly Report No. 3, 
but is again included in its entirety because of the significant cost advantages.

Cost savings realized by application of laser annealing fall into the following categories:

1. Increased cell efficiency with subsequent decrease in the number of cells, support structures, and associated hardware for a 500 megawatt production rate

2. Decrease in energy consumption realized by using laser annealing techniques as opposed to furnace annealing

Savings realized from item 1 above are as follows:

- Area of 3-inch diameter cell $=45.6 \mathrm{~cm}^{2}$

- Illumination Intensity $=100 \mathrm{~mW} / \mathrm{cm}^{2}$

- Total Incident Irradiation $=\left(45.6 \mathrm{~cm}^{2}\right) \times\left(100 \mathrm{~mW} / \mathrm{cm}^{2}\right)=4.56$ watts

- A $12 \%$ conversion efficlency cell ylelds an output of $\sim .55$ watts

- Assuming that laser annealing can yield a $2 \%$ conversion efficiency increase or a $14 \%$ cell, the yield w111 be -.64 watts

- Projected into $1986,500 \mathrm{MW} / \mathrm{yr}$ production capability at $\$ .50 /$ watt, the savings represent

$$
\left[\left(\frac{500 \mathrm{MW}}{.55 \mathrm{~W} / \mathrm{ce} 1 \mathrm{l}}\right)-\left(\frac{500 \mathrm{MW}}{.64 \mathrm{~W} / \mathrm{cel1}}\right)\right] \times .55 \frac{\mathrm{W}}{\mathrm{cel1}} \times \$ .5 / \mathrm{W}=\$ 35,156,250
$$

Savings realized from item 2 above are as follows:

Preliminary theoretical and experimental data indicates that for a ruby or frequency doubled glass laser, an energy density of approximately 1.5 joules $/ \mathrm{cm}^{2}$ is required to attain annealing of ion implanted silicon wafers. This translates to an energy of approximately 68 joules for 
single pulse annealing of a 3-inch diameter wafer. A Q-switched glass laser capable of operating at this energy level with a pulse repetition rate of 1 pps has a conversion efficlency of approximately .5\%. This system offers the following savings:

- Resistance Furnace Power Requirements*

$1.88 \mathrm{KW}$ to maintain $900^{\circ} \mathrm{C}$ annealing temperature 1253 -inch diameter wafers per run @ $30 \mathrm{~min} / \mathrm{run}$ $1.88 \mathrm{KW} \times .5 \mathrm{hr}=.94 \mathrm{~kW}$ hr to anneal 125 cells or $\underline{7.52 \mathrm{~W} \mathrm{hr} / \mathrm{cell}}$

- Laser Power Requirements 68 joules required to anneal a 3 -inch diameter wafer At $.5 \%$ conversion efficiency, the laser requires $68 / .005=13,600$ joules $=3.78$ watt $\mathrm{x} \mathrm{hr}$ to supply the 68 joules

- $7.52 / 3.78 \approx 2$ or half as much energy is required for laser annealing as compared to furnace annealing

- For $500 \mathrm{MW} / \mathrm{yr}$ production capability

$$
\left(\frac{500 \mathrm{MW}}{.55 \mathrm{~W}} \times 7.52 \mathrm{Whr}\right)-\left(\frac{500 \mathrm{MN}}{.64 \mathrm{~W}} \times 3.78 \mathrm{Whr}\right) \approx 3,900 \mathrm{MW} \mathrm{hr} / \mathrm{yr} \text { savings }
$$

\subsubsection{Screen Printed Contacts}

In our technical and economic evaluations of screen printing conductive pastes for ohmic contacting on solar cells, it was agreed that this technique offers the excellent prospects for low cost manufacturing to achieve the 1986 goals. High throughput screen printing equipment is available with rates up to 5000 parts/hour. Screens with 325 mesh can routinely produce patterns with excellent line definition. Screened line widths of $5 \mathrm{mlls}$ have been reported by participants in this LSA PROJECT.

*Thermo-Brute American Furnace, 4-1/2 inch 0.D. Tube Size 
Cost of materials, particularly with the silver filled pastes, is still a concern. Our estimates on large volume buys of the Ag paste approximate a cost of $\$ .05$ to $\$ .15 /$ watt, when applied $100 \%$ on the back, and $5-7 \%$ area coverage for the patterned front side.

Our experience in working with an "approved" Ag-filled paste using documented processes has shown that the process is not yet entirely foolproof. Working with DuPont 7095 material, firing schedules were used which ranged in temperatures from $550^{\circ} \mathrm{C}$ to $690^{\circ} \mathrm{C}$ and times of 20 seconds to 2 minutes with only limited success.

It is recognized that this area, including the copper and aluminum paste materials, is being investigated extensively by other participating firms, and through these efforts, it is believed that this could soon become a viable process.

Our high volume production concept, reported in Quarterly Report No. 3, reflects a screen printing and firing rate of 9000 cells/hour/unit equipment.

\subsubsection{Spray-On AR Coatings}

General concensus is that spray-on AR coatings offers the best chances for high throughput and good coating thickness uniformity over large surface areas. Also, spraying is not as sensitive to irregular surface finishes, such as for texture-etched cells, as compared with spin coating.

A high throughput capability was conceptualized (detailed in Quarterly Report No. 3) where a production rate of 9000 cells/hour/machine was projected.

\subsection{CRITICAL REVIEWS}

\subsubsection{Texture Etching}

It has been fairly well established that the wet chemical process for 
anisotropically texture etching using $1-2 \%$ solution of hot sodium hydroxide can satisfy the 1986 Project goals.

It is felt that further process verification should be conducted to determine the merits of replacing the post etching hydrogen peroxide/sulfuric acid neutralizing step with force flush DI water rinses.

Significant development still required to meet the 1986 cost goals consist of: :

- In-process monitoring of etch solution, textured wafer reflectivity, rinse solution $\mathrm{pH}$, etc.

- Automatic inspection for process uniformity and product quality

- Etch and rinse solution disposal and reclamation

- Equipment automation design and integration of monitor feedback loops

\subsubsection{Ion Implant}

As previously stated, ion implantation is considered a viable approach from both a technical and economic standpoint. At present, off-the-shelf equipment for optimum implantation of solar cells, i.e., <10 KeV @ >10 ma beam current is not readily available, although the technology base exists for fabricating a "dedicated" implanter. Implantation of the presently available higher acceleration voltages ( $>20 \mathrm{KeV}$ ) result in a front surface bucking drift field which reduces cell output unless annealed in a furnace utilizing background doping. Laser annealing, and it is expected E-beam annealing, minimizes this problem. Another technique for minimizing the bucking current drift field is to tailor the impurity profile during implantation. This can be accomplished with a programmed implant cycle that varies beam energy and time, holding the beam current constant. Because of equipment limits (minimum of $25 \mathrm{KeV}$ acceleration voltage), this technique was not verified. 
Major areas for investigation in ion implantation recommended for the 1986 objectives are:

o Ion implantation junction profiling by beam energy programming

- Development and fabrication of a high beam current, high throughput, dedicated ion implanter

\subsubsection{Laser Annea 1}

Reduction of the annealing process time and energy consumption with the use of pulsed laser energy beams offers excellent prospects for achieving the high volume, high throughput goals of the PROJECT.

Equipment limitations were experienced during our work on laser annealing. Most of the lasers available for our work were of low energy, delivering smal1 beam spot sizes at the energy densities needed for annealing. Equipment is available* from established cataloged product lines which is capable of delivering energies required for single pulse annealing of 3-inch diameter wafers. This equipment, however, was not available for evaluation. Ruby lasers with a wavelength of $694 \mathrm{~nm}$ are well suited for laser annealing, however, suffer in the scale up to accommodate wafers beyond approximately 1.4 inches in diameter. The maximum size of the available ruby rod is $7 / 8$ inch in diameter delivering only 15 joules of energy, and therefore, necessitating step and repeat mode of processing for annealing 3-inch diameter wafers. Glass rod lasers on the other hand do not suffer from this limitation and are, therefore, ideally suited for annealing of large size wafers.

Laser pulse annealing in the energy densities required for suitable ion activation causes surface melting. This has no deleterious effects on the cell junction for polished or flash-etched cells. With texture-etched cells, the prominent pyramidal structures are significantly changed, a condition which appears to cause junction non-uniformity hence adversely affecting the cell function.

*Quantel International, 928 Benecia Avenue, Sunnyvale, Ca. 94086 (408) 735-7313 
Even though texture-etched surface cells have received general acceptance for the reason of improved solar absorption over other surface types, a case could be made for utilizing flash-etched cells with laser annealing followed by the projected low cost spraying of AR coating. We have found that electrical output of flash-etched/AR-coated cells are comparable to the texture-etched/AR-coated cells. Substitution of flash etching for texture etching could contribute to reduced costs without compromising performance, since a coating of some type will be required in either case.

It is difficult to declare any major technical shortcomings of the laser annealing process at this time. Perhaps, the fact that the single 3-inch diameter pulse has not been demonstrated could be cause for some concern. It follows that additional experimentation should be done with lasers capable of annealing at least a 1 -inch diameter area. From this we can ascertain $=$ beam energy uniformity across the wafer surface together with recognition of the need for better optics.

Major areas of investigation required in order to meet the 1986 goals are:

- Process interdependence data of the relationship of wafer surface melting vs. junction movement vs. reflectivity vs. AR coating

- Laser beam control using optics to improve beam energy homogeneity on wafer surfaces

- Acquire a capability for scale-up performance of laser annealing

\subsubsection{Screen Printing}

Screen printing of ohmic contacts is feasible insofar as line definition and conductor thickness are concerned. Considerable difficulty can still be expected in firing the pastes after screening. In addition, the quality of pastes from lot to lot is highly suspect. In performing our process verification tests several points of critique were uncovered, namely: 
- Closer control (specification) of conductor paste must be made.

- Presently available belt furnaces are not adequate to accomodate short firing duration pastes (e.g., in the 10 to 30 second range).

- Use of silver and silver-aluminum pastes are too expensive to meet PROJECT cost goals.

- Glass-lined belt furnaces should be evaluated to facilitate perfodic clean ing.

- Use of diffusion tube firing is both expensive (energy) and slow (difficult to automate).

\subsubsection{Spray-On AR Coatings}

Spray coating of an AR film has shown good promise as a cost effective, high throughput process. Equipment is presently available which exhibits controllable parameters necessary to deposit these coatings. However, the most precise spray nozzles and vapor spreaders presently avallable from the equipment manufacturer limited our uniformity of coated film width to $3 / 4$ inches. Increasing the nozzle height normally widens the deposited film on the cell, but in this case, film thickness uniformity was compromised. It appears that additional effort is required to optimize nozzle and vapor spreader configuration and design.

\subsection{PROCESS VERIFICATION}

\subsubsection{Texture Etching}

The texture etching process was performed as part of this contract to verify its adequacy to meet the ISA objectives, and to fabricate cells for use in evaluating the rest of our process sequence.

The procedure, as supplied for use in processing as-sawn wafers, called for a flash etch step consisting of a nitric ( HNO $_{3}$ ) - hydrofluoric (HF) - acetic 
acid $\left(\mathrm{CH}_{3} \mathrm{OOH}\right)$ solution, followed by sodium hydroxide $(\mathrm{NaOH})$ texturizing and a neutralizing step of hydrogen peroxide $\left(\mathrm{H}_{2} \mathrm{O}_{2}\right)$ - sulfuric acid $\left(\mathrm{H}_{2} \mathrm{SO}_{4}\right)$ rinse.

The flash etch step was deemed too costly to meet the overall PROJECT cost objectives, and was subsequently eliminated without any apparent deleterious effects on the performance of the cells. The procedure used calls for a $1 \%$ solution of $\mathrm{NaOH}$ followed by the $\mathrm{H}_{2} \mathrm{O}_{2} / \mathrm{H}_{2} \mathrm{SO}_{4}$ neutralizing step and $\mathrm{DI}$ water rinses. Wafers processed by this modified texture etch process are typified in the photomicrograph shown in Figure 2.

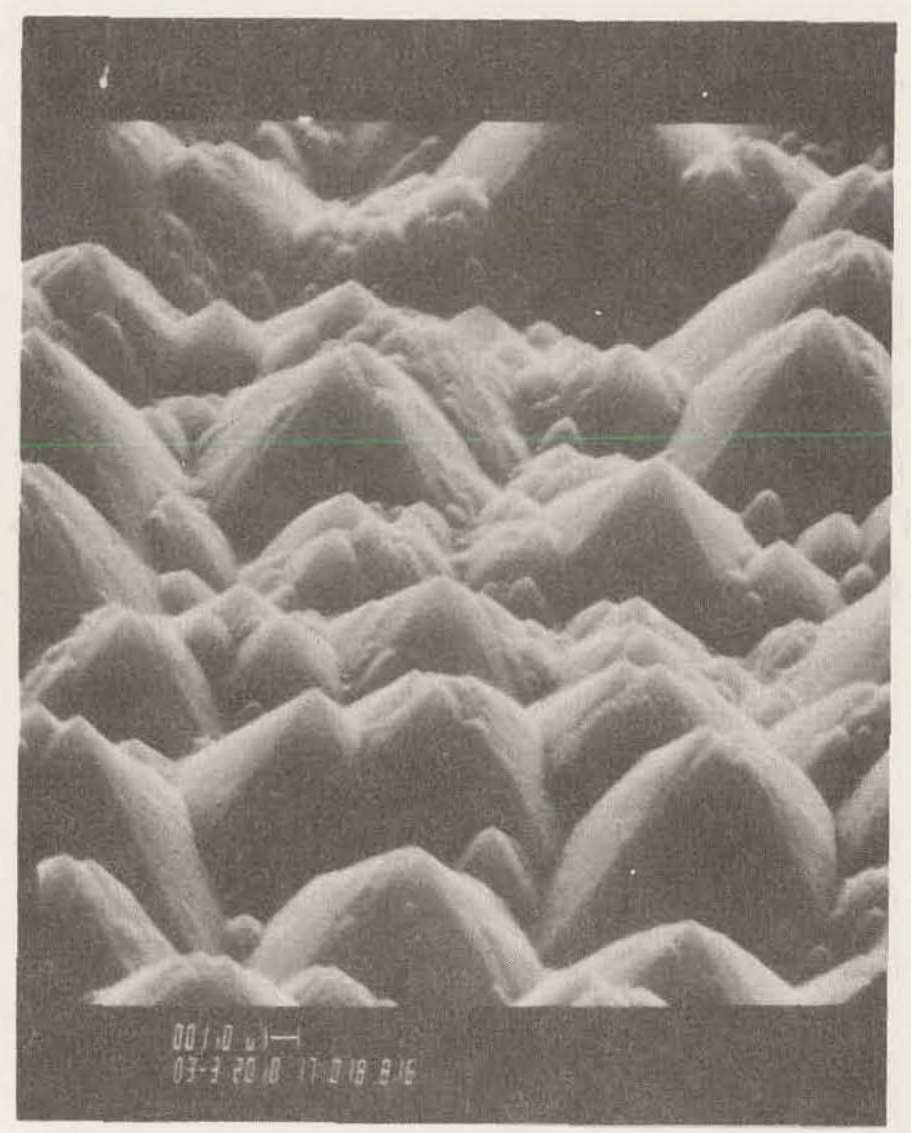

Figure 2. SEM Photomicrograph of Typical Texture-Etched $\langle 100\rangle$ Silicon Wafer Using $1 \%$ Solution of $\mathrm{NaOH}$ 
The hydrogen peroxide/sulfuric acid neutralizing rinse has been eliminated in our projected high volume, high throughput process, as we believe that the simpler dilute $\mathrm{H}_{2} \mathrm{SO}_{4}$ acid rinse will suffice if followed by multiple DI water sprays. The projected process is detailed in Quarterly Report No. 2.

Due to the time and cost involved in repeated process checks by SEM analysis, required for control of this process, an in-line tester was constructed and used. This instrument was constructed as a quick reference to check the reflectance of the texturized surfaces being produced and was useful regardless of the texturizing process used. It consists of directing light from a light tower through a hole in a black box at normal incidence to the surface of the silicon wafer being measured. Light from the irradiated surface is reflected to silicon photocells mounted on the under surface of the "black box" top, adjacent to the light entrance hole. Short circult current measurements of these photodetectors give relative reflectance values. For example, semi-polished chemically etched wafer surface exhibited approximately 4 times the reflectance of the $\mathrm{NaOH}$ etched groups. This kind of in-process testing (reflectance) could be a regular feature for Q.A. control of textureetched surfaces and to serve as an adjunct to other generally employed criteria such as SEM analysis. In addition, this type reflectance measurement may later be utilized as a means for screening/categorizing cells for laser anneal, where the reflectance may influence power settings on the laser.

Cells were fabricated in identical fashion except for the wafer surface finishes to verify the adequacy of our texture-etched process. One run was flash etched (非117) and the other texture etched (非118). The POCL diffusion process was used for junction formation with electroless nickel-plated solder-coated contacts and evaporated SiO coatings. Both types of cells exhibited $10 \%$ conversion efficiencies with fill factors of $75 \%$ and $67 \%$, respectively. Figures 3 and 4 show representative I-V curves from these runs. 


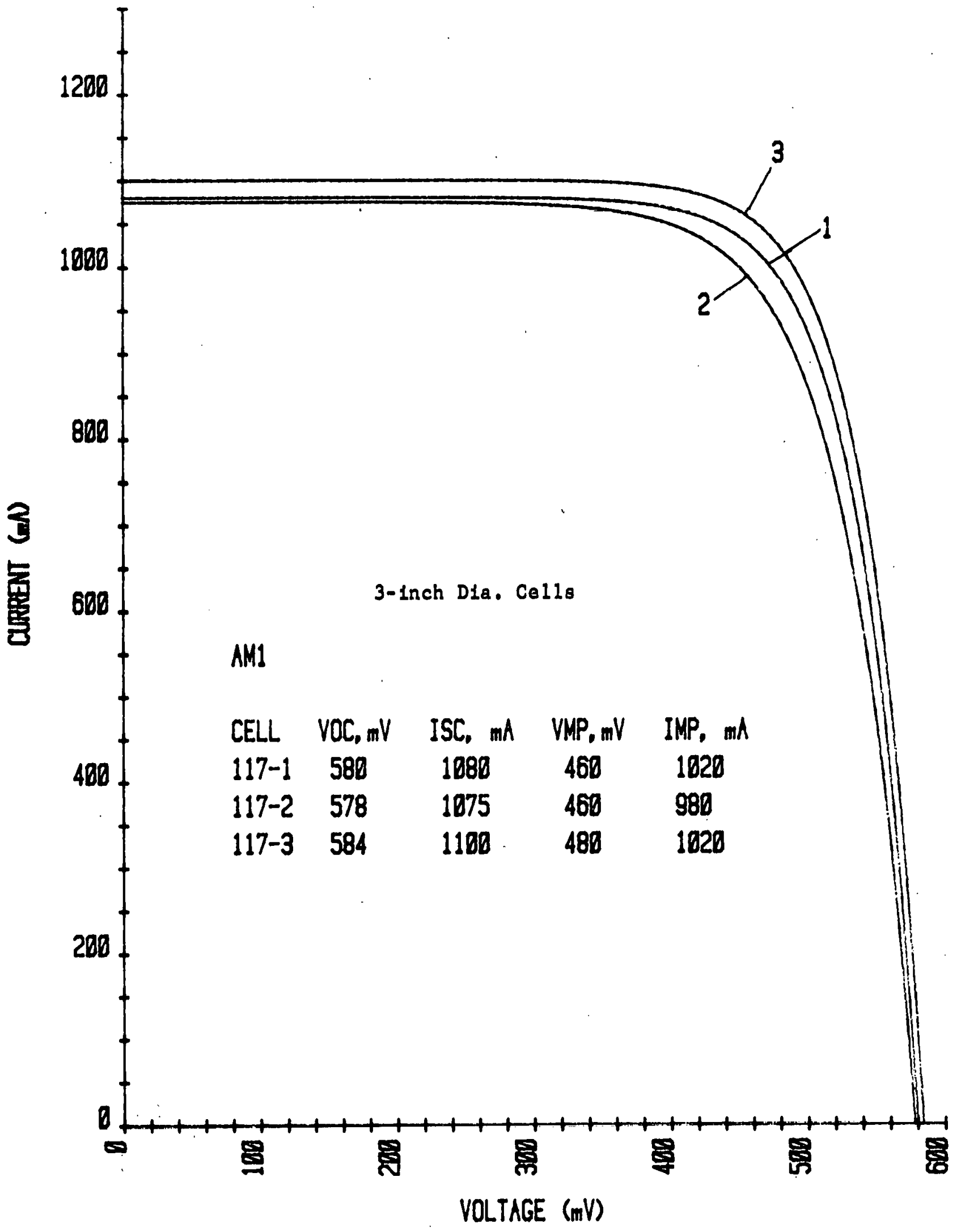

Figure 3. I-V Output for Run No. 117, Cells 1, 2, and 3 


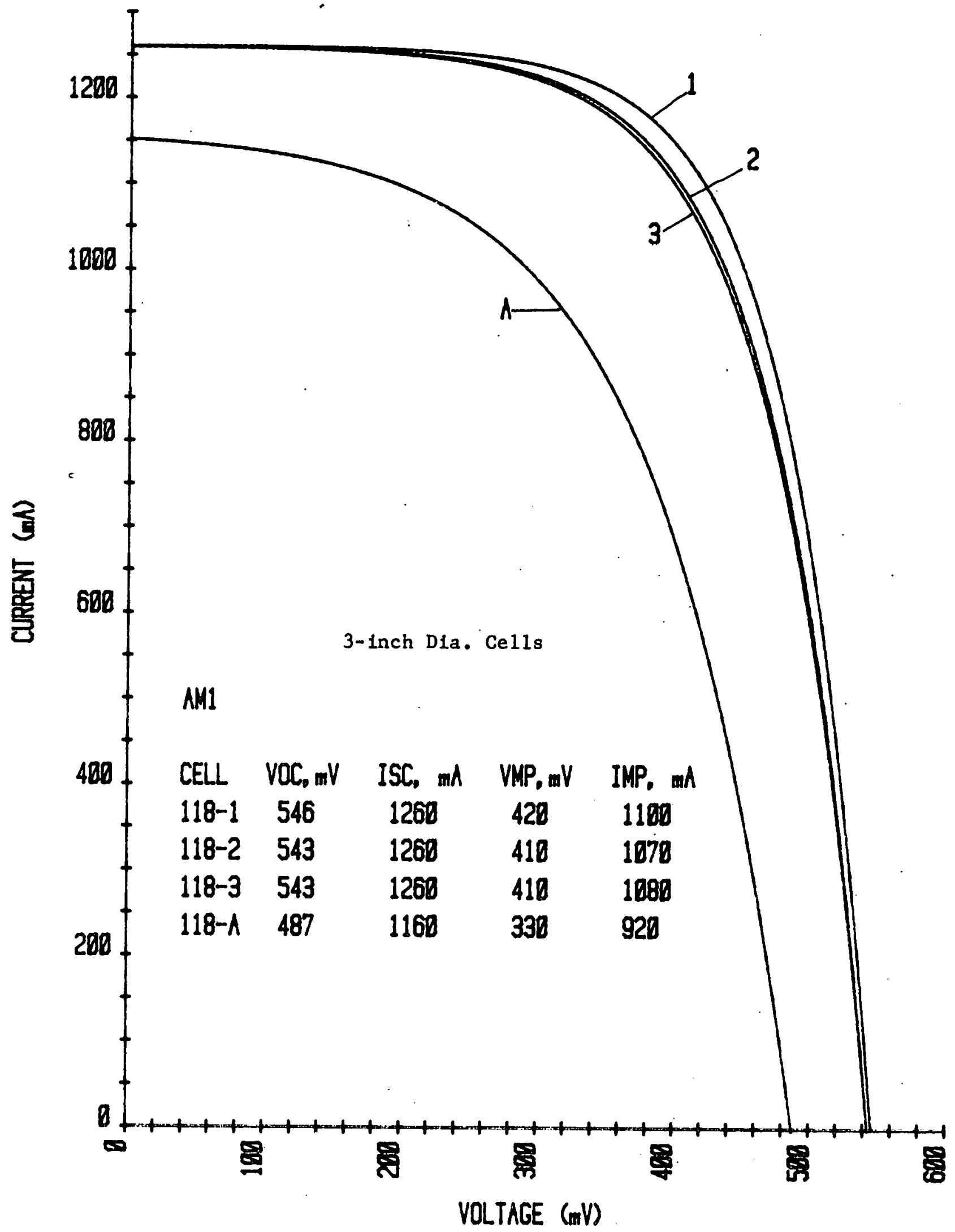

Figure 4. I-V Output for Run No. 118, Cells $1,2,3$ and 4 


\subsubsection{Ion Implantation}

Verification of ion implantation as a viable process for doping solar cells was accomplished using an Extrion 20-200 (International Rectifier) and an Acceleration, Inc. MP-400 (Lockheed) implanter. Several runs were initially made using implant energy variations ranging from $25 \mathrm{KeV}$ to $140 \mathrm{KeV}$ to determine equipment parameter and effect on cell performance. The higher energy level tests were implanted through $\mathrm{SiO}_{2}$ to 1 imit ion penetration and reduce the effect of the bucking drift field effect resulting at the front surface due to the Gaussian ion distribution. Fluence dosage levels were varied from $1 \times 10^{15}$ to $3 \times 10^{15}$ ions $/ \mathrm{cm}^{2}$ for the ${ }^{31} \mathrm{P}$ dopant. Table 1 shows some of the parameters investigated during the initial test phase.

Some of the initial ion-implanted cells completed for "first look" used the following sequence:

- 3-inch diameter wafer, texture-etched

- Ion implanted, $50 \mathrm{KeV}, 1 \times 10^{15} / \mathrm{cm}^{31} \mathrm{P}$

- Therma 1 annea $1,900^{\circ} \mathrm{C} / 15$ minutes

- Screened-on grid resist

- Electroless nickel plate front and back

- Resist remova 1

- Edge-etch

- Solder dip

Electrical outputs of two cells processed using the above sequence as measured with a Spectrolab X-25 Solar Simulator are shown in Figure 5. The cell outputs as measured at AMO represent $7 \%$ efficiency at Pmax. This converts to approximately $9 \%$ at AMI. 
TABLE 1

WAFER IMPLANTATION PARAMETERS

\begin{tabular}{|c|c|c|c|}
\hline \multirow[b]{2}{*}{$\begin{array}{l}\text { Surface } \\
\text { Condition }\end{array}$} & \multirow[b]{2}{*}{ Beam Energy/Dosage } & \multicolumn{2}{|c|}{ Imp lanter } \\
\hline & & $\begin{array}{l}\text { Extrion } \\
\text { (IR) }\end{array}$ & $\begin{array}{c}\text { Acceleration } \\
\text { (IMSC) }\end{array}$ \\
\hline $\mathrm{TE}$, No Oxide & $50 \mathrm{KeV} / 1 \times 10^{1531} \mathrm{P}$ & $\mathrm{x}$ & \\
\hline TE, Oxide & $125 \mathrm{KeV} / 1 \times 10^{1531_{\mathrm{P}}}$ & & $\mathrm{x}$ \\
\hline TE, Oxide & $\begin{array}{l}125 \mathrm{KeV} / 1 \times 10^{15} 31_{\mathrm{P}} \\
150 \mathrm{KeV} / 5 \times 10^{14} 11_{\mathrm{B}}\end{array}$ & & $\mathrm{x}$ \\
\hline Pol. Oxide & $125 \mathrm{KeV} / 1 \times 10^{1531_{\mathrm{P}}}$ & & $\mathrm{x}$ \\
\hline $\mathrm{TE}$, Oxide & $125 \mathrm{KeV} / 1 \times 10^{1531} \mathrm{P}$ & & $\mathrm{x}$ \\
\hline TE, Oxide. & $\begin{array}{l}125 \mathrm{KeV} / 1 \times 10^{15} 31_{\mathrm{P}} \\
200 \mathrm{KeV} / 1 \times 10^{15} 11_{\mathrm{B}}\end{array}$ & & $\mathrm{x}$ \\
\hline $\mathrm{TE}$, Oxide & $\begin{array}{l}140 \mathrm{KeV} / 2 \times 10^{15} 31_{\mathrm{P}} \\
\text { Evap. Alum. BSF }\end{array}$ & . & $\mathrm{x}$ \\
\hline TE, Oxide & $25 \mathrm{KeV} / 1 \times 10^{1531_{\mathrm{P}}}$ & $\mathrm{x}$ & \\
\hline TE, No Oxide & $\begin{array}{r}25 \mathrm{KeV} / 3 \times 10^{15}{ }^{31} \mathrm{P} \\
150 \mathrm{KeV} / 5 \times 10^{15} 11_{\mathrm{B}} \\
\end{array}$ & & $\mathrm{x}$ \\
\hline $\mathrm{FE}$, Oxide & $65 \mathrm{KeV} / 3 \times 10^{1531} \mathrm{P}$ & $\mathrm{x}$ & \\
\hline FE, Oxide & $\begin{array}{l}25 \mathrm{KeV} / 1 \times 10^{1531} \mathrm{P} \\
\text { Evap. Alum. BSF }\end{array}$ & $\mathrm{x}$ & \\
\hline
\end{tabular}

NOTE: All Wafers $3^{\prime \prime}$ diameter, 1:0:0 Orientation, $7^{\circ}$ Angle Implants 


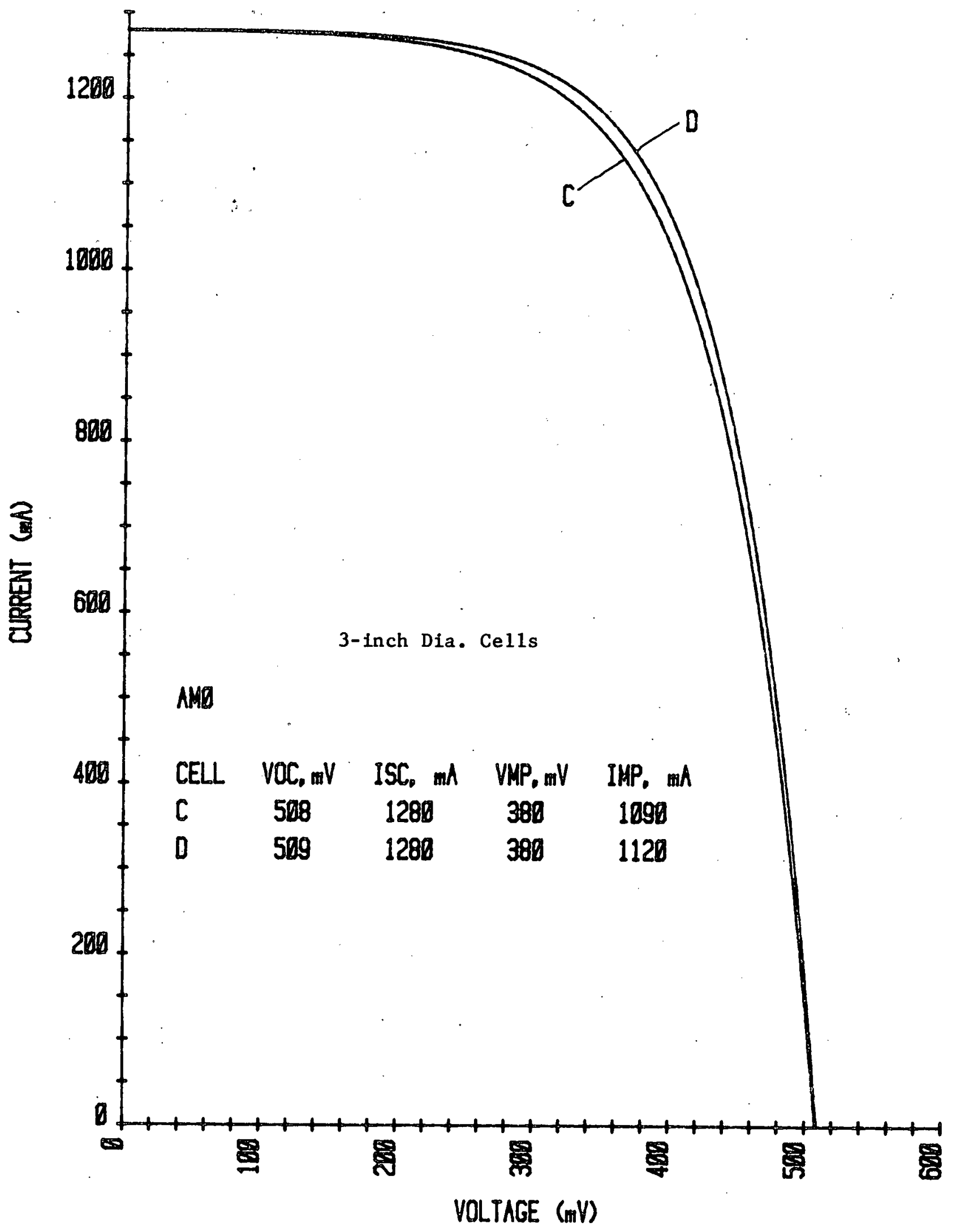

Figure 5. Output Curves for Two Baseline Cells 
It became apparent that implanting through oxide was not cost effective and due to the lower practical acceleration level of the MP-400 $\approx 50 \mathrm{KeV})$ further use of this system was discontinued. It was in fact evident that the lower practical energy level of the Extrion 20-200 $\approx 25 \mathrm{KeV})$, while adequate for process verification studies, was also too high for any practical production of solar cells. To meet the goals of this program, a dedicated system of high beam current ( $510 \mathrm{ma}$ ) at low acceleration voltage $(<10 \mathrm{KeV})$ is required. Even at the $10 \mathrm{KeV}$ level there is some concern regarding the bucking drift field previously mentioned. One method considered to minimize this effect was discussed in Section 3.2.2.

As a result of the initial tests, a 11 runs made for subsequent processing, 1.e., laser anneal, screen printing, and spray-on AR coating, were made at $25 \mathrm{KeV}$ (our practical minimm) and at fluence levels of $1 \times 10^{15}$ to $3 \times 10^{15}$. Results of these are discussed in their respective sections.

\subsubsection{Laser Annealing}

In the course of this investigation, annealing work was carried out with lasers made by a variety of manufacturers. The ruby lasers evaluated were made by Korad and Apollo. Nd:YAG lasers, with and without a second harmonic generator, were made by Quanta-Ray, Quante1, Quantronix, ESI/Holobeam, and Raytheon. With the exception of the Raytheon laser, all other lasers were Q-switched with pulse duration in the 10-250 ns range. The Raytheon laser was a conventionally pulsed system with pulse durations between $.6-5 \mathrm{msec}$.

In evaluating the Raytheon laser, it became apparent that this laser, with its long pulse duration and a $1064 \mathrm{~nm}$ wavelength, was inadequate for the required annealing work. The combination of the stated output parameters led to heating of the bulk material, with subsequent cracking of the silicon substrate from the thermally induced stresses. Similar investigations with Q-switched lasers revealed satisfactory performance, with annealing attained without substrate damage. 
The Q-switched lasers evaluated can be divided into two categories.

1. Repetitively pulsed, Q-switched lasers, or those whose continuous wave emission is converted into pulses by a Q-switch. The Quantronix and ESI/Holobeam laser scribers/trimmers fall into this category.

2. Pulsed lasers, or lasers that emit light in pulses rather than continuously and where the Q-switch increases pulse power by shortening pulse duration while keeping the energy constant. Korad, Apo11o, Quantel, and Quanta-Ray are manufacturers of pulsed lasers.

Category 1 lasers are of low energy and high pulse repetition rate (less than a millijoule in the $\mathrm{KHz}$ range); whereas, category 2 lasers evaluated were generally of high energy and low repetition rate (.1-5 joules of 2-5 pulses/ minute).

When annealing with laser scribers/trimmers, the beam was defocused to provide a spot 1-5 mils in diameter. To ensure complete area coverage, a computer controlled step and repeat process was utilized with approximately a $50 \%$ to $80 \%$ overlap from spot to spot. For the high energy lasers, a computerized $X-Y$ positioning table was not available; however, the larger diameter annealed spots created by high laser energy allowed manual repositioning of the wafer through utilization of appropriate micrometer positioning devices.

Throughout this investigation, laser annealing was performed on silicon wafers consisting of texture-etched, flash-etched, and polished specimens which were implanted at various energies (25 KeV - $125 \mathrm{KeV})$ and fluence levels $\left(1 \times 10^{15}\right.$ ions $/ \mathrm{cm}^{2}-3 \times 10^{15}$ ions $\left./ \mathrm{cm}^{2}\right)$. After annealing, the wafers were subjected to four point probe measurements to determine proper electrical activation. This was followed by electrical output testing at AMl for data on cell electrical characteristics for those annealed specimens fabricated in to sma 11 cells. 
Consistently, I-V outputs for laser annealed texture-etched cells were extremely low. SEM analysis of cell surfaces revealed some melting of the pyramidal structure during the laser annealing operation, Figure 6 . It was concluded that melting caused junction non-uniformity with subsequent cell output degradation. Attempts at resolving this problem by reducing laser pulse energy, and for some samples preheating the substrate, were unsuccessful. At settings where melting was minimized, sufficient surface activation was not attained as indicated by high sheet resistivity readings when tested with a four point probe system.

Low I-V outputs were also experienced with laser-annealed flash-etched wafers. These low outputs were expected by virtue of high sheet resistivity readings $(70 \Omega / s q)$ ylelded by the tested specimens. High reslstivity was attributed to low Ion implantation fluence level of $1 \times 10^{15}$ lons $/ \mathrm{cm}^{2}$ as compared to optimized level of $2.5 \times 10^{15}-3 \times 10^{15}$ lons $/ \mathrm{cm}^{2}$ utilized on polished and texture-etched wafers and ylelding sheet resistivities of $\leq 45 \Omega / \mathrm{sq}$.

The first phase of laser annealing work on polished wafers was performed on wafers Implanted at $25 \mathrm{KeV}-2.5 \times 10^{15}$ lons $/ \mathrm{cm}^{2}$. Sample cells fabricated from the annealed wafer areas ylelded an output representing $7.3 \%$ AMI conversion efficlency, Figure 7. The cells were ne1ther sintered nor AR coated, consequently higher conversion efficlencles would have been obtained with incorporation of these two techniques into cell processing. In terms of $I_{B c}$ per unit area, the laser-annealed pollshed cells demonstrated a falrly good response. The $5 \mathrm{ma} I_{8 c}$ for the $.5 \times .5 \mathrm{~cm} \mathrm{size}$ cell converts to a value of 27 $\mathrm{ma} / \mathrm{cm}^{2}$ based on active area only, discounting the ohmic contacting and probe masking during test. Th1s compares to a diffused Junction $11 \%$ efficient cell, Figure 8 , with an $I_{s c}$ output of $32 \mathrm{ma} / \mathrm{cm}^{2}$, discounting a $7 \%$ ohmic contacting masking area.

This work was followed by additional laser annealing of polished wafers Implanted at $25 \mathrm{KeV}, 3 \times 10^{15}$ ions $/ \mathrm{cm}^{2}$. Annealing was carried out with a Quantronix Nd:YAG laser scrlber, Korad ruby laser, and ESI/Holobeam Nd:YAG 


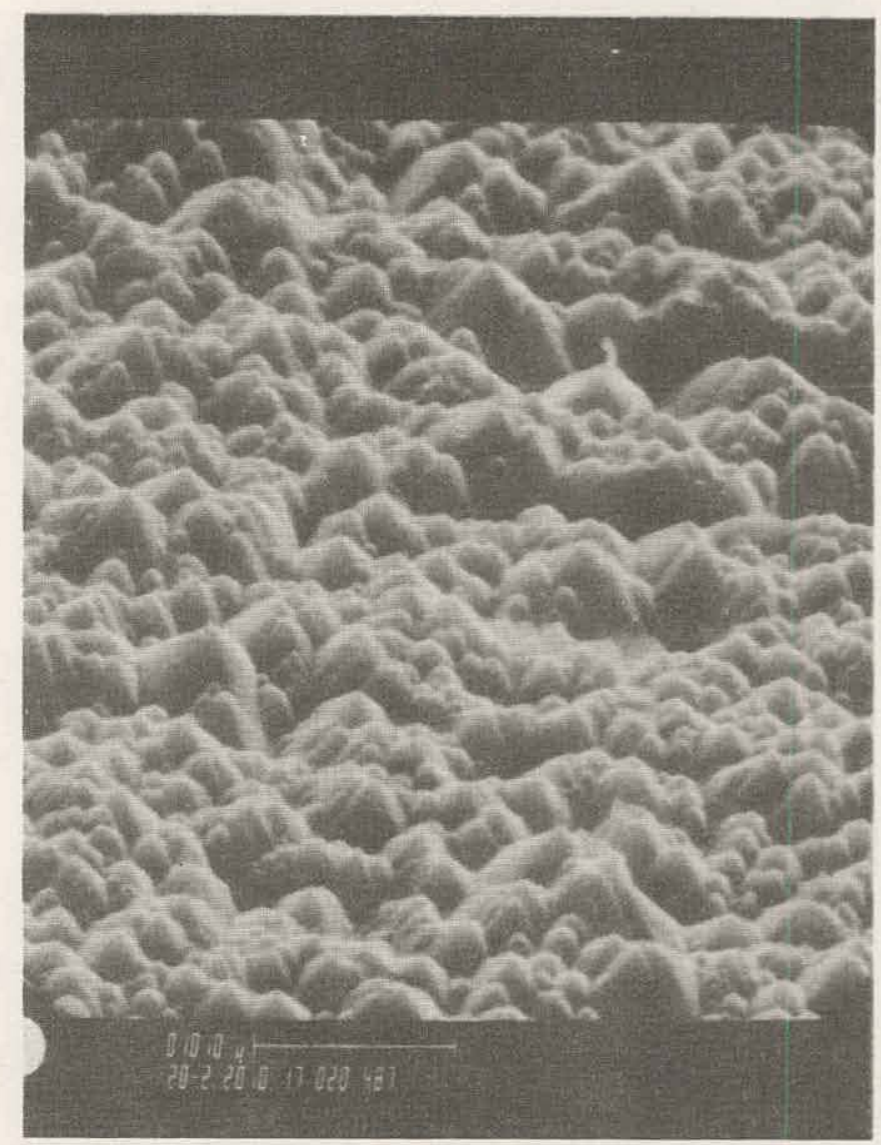

(A)

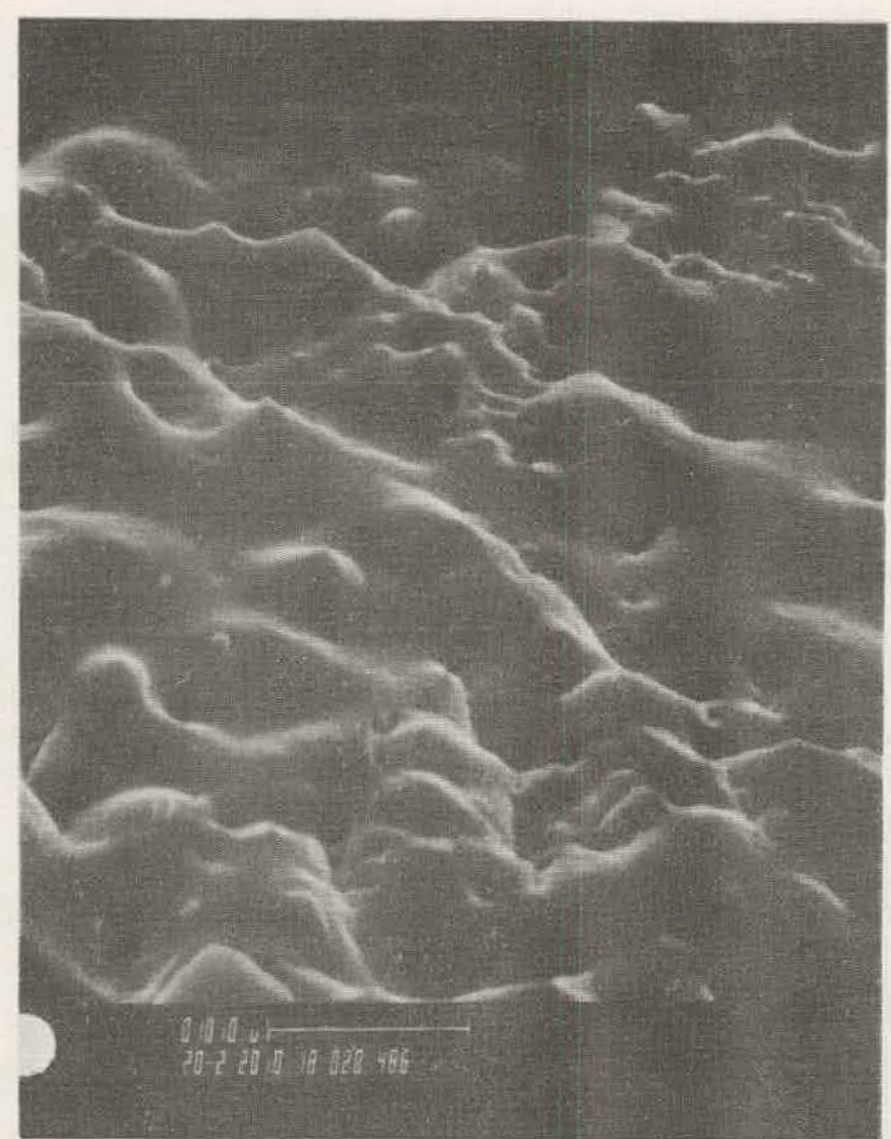

(B)

Figure 6. SEM photos $\left(2000 \mathrm{x} / 60^{\circ} \mathrm{Tilt}\right)$ of the Surface of a Texture-Etched/Ion Implanted Silicon Wafer before (A) and after Laser Annealing (B) 


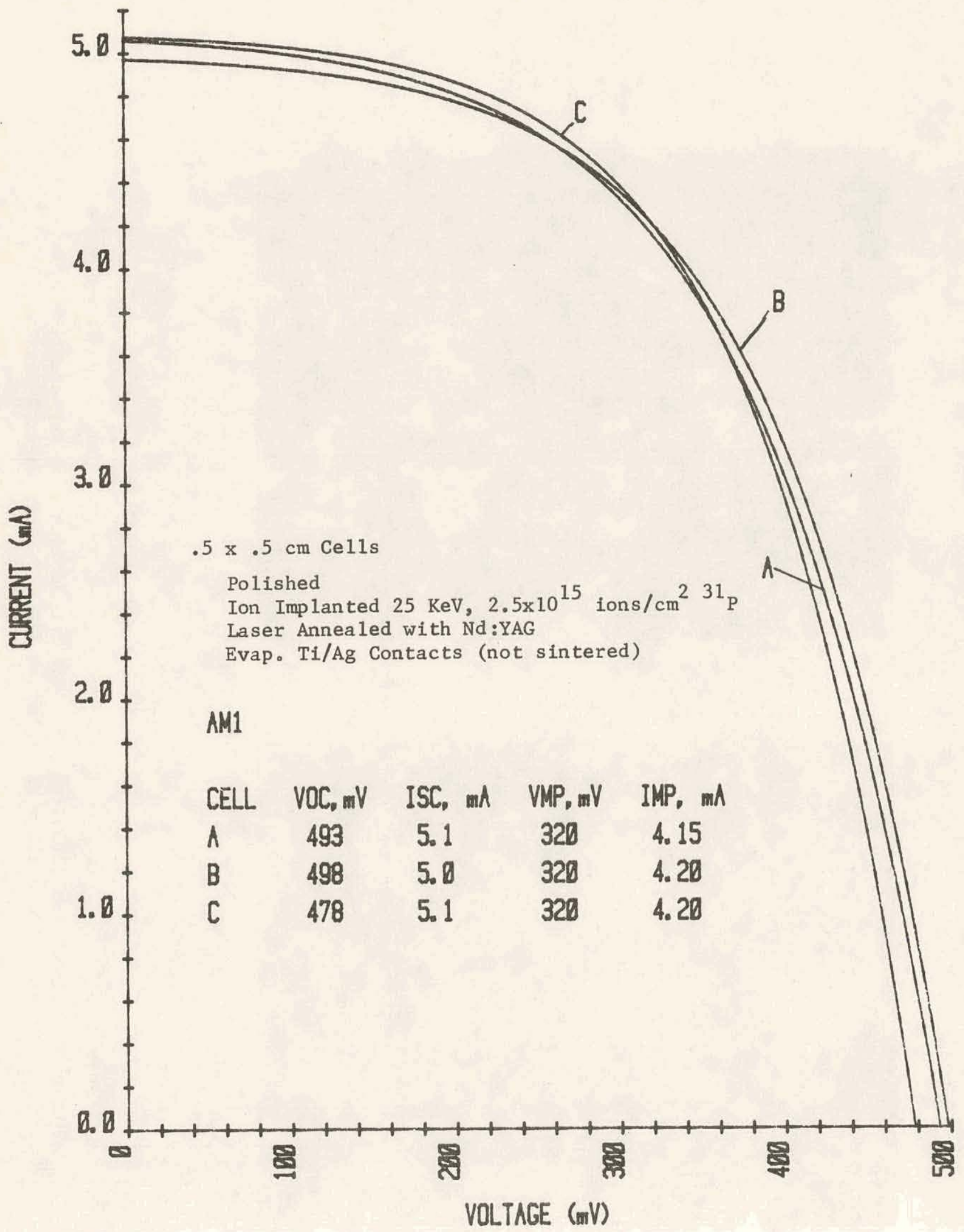

Figure 7. I-V Output for Laser Annealed Solar Cells 


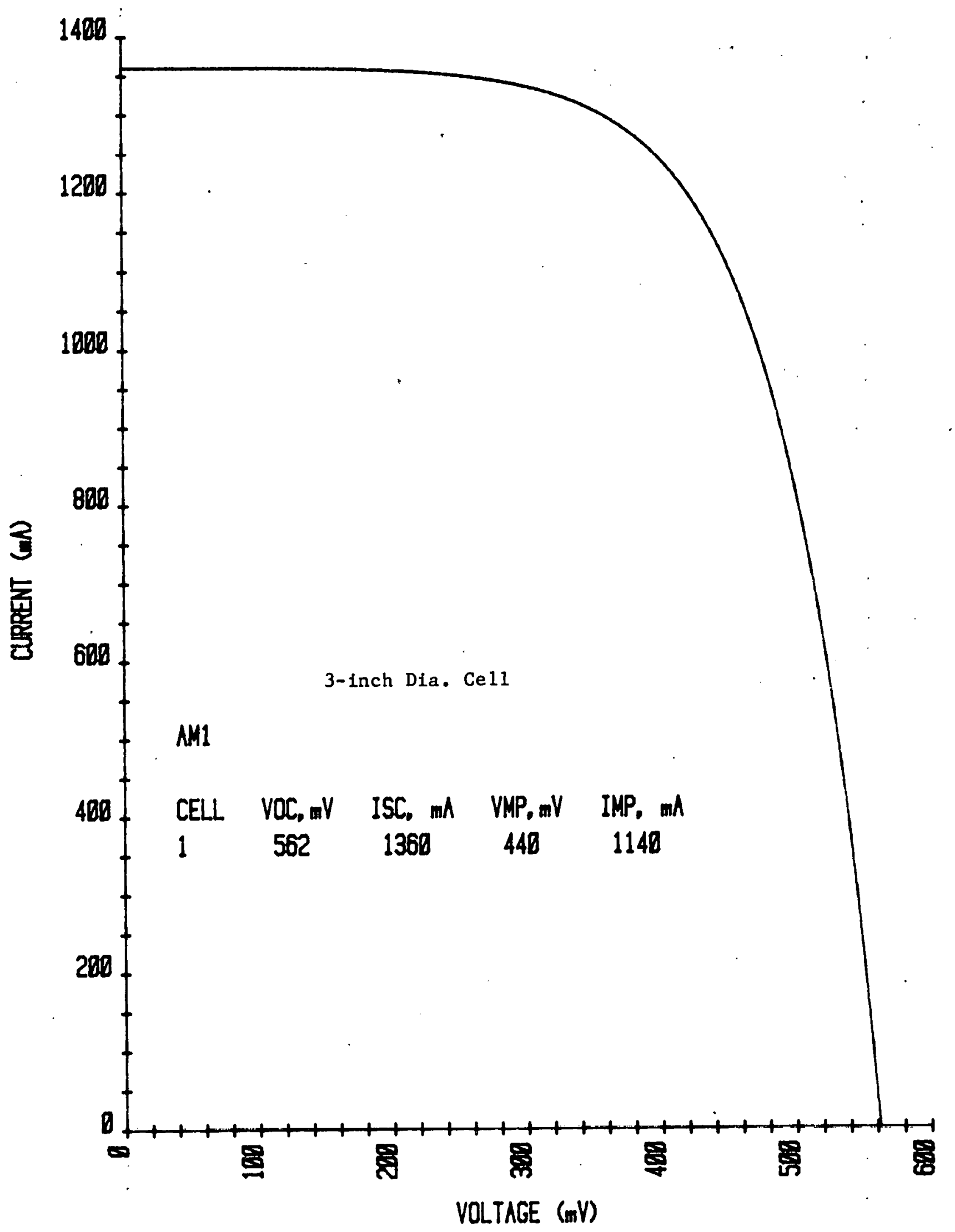

Figure 8. STD Terrestrial Cell 
laser scriber and laser trimmer. The annealed regions on the wafers exhibited good sheet resistivity values - approximately $31 \Omega / \mathrm{sq}$. The regions also exhibited a color change associated with good annealing.

At the onset of the second phase annealing work, the ruby laser was damaged before a large enough area on a wafer could be annealed to allow test cell fabrication. Consequently, the only cells made were annealed with Nd:YAG lasers. At this time, the cells were sintered and AR coated, subsequently yielding a conversion efficiency of up to $13.25 \%$ or $14.73 \%$ in terms of active area only for a $2 \times 4 \mathrm{~cm}$ cell. With optimization of laser annealing parameters, this efficiency could be pushed above $16 \%$.

Somewhat lower conversion efficiencies were obtained with the two 3-inch diameter cells $-10.4 \%$ and $10.7 \%$. It was felt that the lower output was partially due to our $I-V$ test set up where the required test fixtures for these 3-inch diameter cells were inadequate.

In addition, the cells suffered from a fairly large ohmic contact area which substantially reduced the active area of the cell with subsequent reduction in cell output. In terms of the active area, the efficiency of the two cells converts to approximately $12 \%$. Obviously, higher output is anticipated with utilization of proper fixtures for cell electrical testing. Table 2 and Figures 9 through 13 summarize the results of this effort.

To: study impurity redistribution following laser and furnace annealing, a number of specimes were subjected to SIMS (Secondary Ion Mass Spectrometry) analysis. SIMS analysis was performed utilizing an ARL (Applied Research Laboratories) ion microprobe mass analyzer (IMMA) interfaced to a PDP- 11 computer. Figures 14 through 16 show the depth profiles obtained from this evaluation.

The sharp peak in Figure 14 is typical for an ion implanted sample (25 KeV, $3.0 \times 10^{15}$. ions $/ \mathrm{cm}^{2}$ ). The broader profiles indicate phosphorus redistribu- 
TABLE 2

SUMMARY OF LASER ANNEALING WORK

\begin{tabular}{|c|c|c|c|c|c|c|c|c|c|c|c|}
\hline $\begin{array}{l}\text { Ce11 } \\
\text { Size } \\
(\mathrm{cm})\end{array}$ & $\begin{array}{c}\text { Wafer } \\
\text { Surface }\end{array}$ & $\begin{array}{l}\text { Imp lan- } \\
\text { tation } \\
\text { Parame- } \\
\text { ters }\end{array}$ & $\begin{array}{l}\text { Laser } \\
\text { Annea } 1 \\
\text { Energy } \\
\text { Density } \\
\left(\mathrm{J} / \mathrm{cm}^{2}\right)\end{array}$ & $\begin{array}{l}\text { Pulse } \\
\text { Duration/ } \\
\text { Pulse } \\
\text { Rep } \\
\text { Rate }\end{array}$ & $\begin{array}{c}\text { Annea led } \\
\text { Spot } \\
\text { Diam } \\
\text { (mils) }\end{array}$ & $\begin{array}{l}\text { Center- } \\
\text { Center } \\
\text { Spacing } \\
\text { (mils) }\end{array}$ & $\begin{array}{l}\text { Sheet } \\
\text { Resis- } \\
\text { tivity } \\
(\Omega / s q)\end{array}$ & $\begin{array}{l}\text { Laser } \\
\text { Type }\end{array}$ & $\begin{array}{c}\text { Cell } 1 \\
\text { Conversion } \\
\text { Efficiency } \\
(\%)\end{array}$ & $\begin{array}{c}\text { Typical } \\
\text { Fil1 } \\
\text { Factor } \\
(\%)\end{array}$ & $\begin{array}{l}\quad \text { Cell } \\
\text { Conversion } \\
\text { Efficiency } \\
\text { In Terms } \\
\text { of Active } \\
\text { Area }(\%)\end{array}$ \\
\hline $1 \times 1$ & $\begin{array}{l}\text { Flash } \\
\text { Etched }\end{array}$ & $\begin{array}{l}25 \mathrm{KeV} \\
1 \times 10^{15} / \mathrm{cm}^{2}\end{array}$ & 4.9 & $\begin{array}{l}140 \mathrm{nsec} \\
4 \mathrm{KHz}\end{array}$ & 2.9 & 1.0 & 70 & $\begin{array}{l}\text { Quantronix } \\
\text { Nd:YAG } \\
\text { Scriber }\end{array}$ & Low & - & - \\
\hline $1 \times 1$ & $\begin{array}{l}\text { Texture } \\
\text { Etched }\end{array}$ & $\begin{array}{l}25 \mathrm{KeV} \\
3 \times 10^{15} / \mathrm{cm}^{2}\end{array}$ & 2.9 & $\begin{array}{l}140 \mathrm{nsec} \\
4 \mathrm{KHz}\end{array}$ & 4.3 & 2.0 & 41 & $\begin{array}{l}\text { Quantronix } \\
\text { Nd:YAG } \\
\text { Scriber }\end{array}$ & Low & - & - \\
\hline $.5 x .5$ & Polished & $\begin{array}{l}25 \mathrm{KeV} \\
2.5 \times 10^{15} / \mathrm{cm}^{2}\end{array}$ & 3.4 & $\begin{array}{l}140 \mathrm{nsec} \\
4 \cdot \mathrm{KHz}\end{array}$ & 4.0 & 1.5 & 38 & $\begin{array}{l}\text { Quan tronix } \\
\text { Nd:YAG } \\
\text { Scriber }\end{array}$ & 7.3 & - & - \\
\hline$\frac{1 \times 2}{\frac{2 \times 4}{3^{\prime \prime} \text { diam }}}$ & Polished & $\begin{array}{l}25 \mathrm{KeV} \\
3 \times 10^{15} / \mathrm{cm}^{2}\end{array}$ & 4.7 & $\begin{array}{rl}95 & \mathrm{nsec} \\
4 \mathrm{KHz}\end{array}$ & 5.0 & 1.5 & $31-35$ & $\begin{array}{l}\text { Quantronix } \\
\text { Nd:YAG } \\
\text { Scriber }\end{array}$ & $\frac{10.88-12.91}{\frac{11.71-13.25}{10.4 / 10.7}}$ & $\frac{76}{\frac{74}{66}}$ & $\frac{12.1-14.35}{\frac{13.0-14.73}{11.85-12.13}}$ \\
\hline $1 \times 2$ & Polished & $\mid \begin{array}{l}25 \mathrm{KeV} \\
3 \times 10^{15} / \mathrm{cm}^{2}\end{array}$ & 3.7 & $\begin{array}{l}100 \mathrm{nsec} \\
5 \mathrm{KHz}\end{array}$ & 5.0 & 0.9 & 45 & $\begin{array}{l}\text { Quantron ix } \\
\text { Nd:YAG } \\
\text { Scriber }\end{array}$ & $11.88-12.58$ & 75 & $13.2-14.0$ \\
\hline $1 \times 1.7$ & \multirow{2}{*}{ Polished } & \multirow{2}{*}{$\begin{array}{l}25 \mathrm{KeV} \\
3 \times 10 / \mathrm{cm}\end{array}$} & \multirow{2}{*}{8.6} & \multirow{2}{*}{$\begin{array}{l}115 \mathrm{nsec} \\
1 \mathrm{KHz}\end{array}$} & \multirow{2}{*}{1.0} & \multirow{2}{*}{.5} & \multirow{2}{*}{31} & \multirow{2}{*}{$\begin{array}{l}\text { ESI/ } \\
\text { Holobeam } \\
\text { Nd:YAG } \\
\text { Scriber }\end{array}$} & 10.1 & \multirow{2}{*}{76} & 11.2 \\
\hline $1 \times 1.9$ & & & & & & & & & 11.2 & & $12.43^{\circ}$ \\
\hline
\end{tabular}




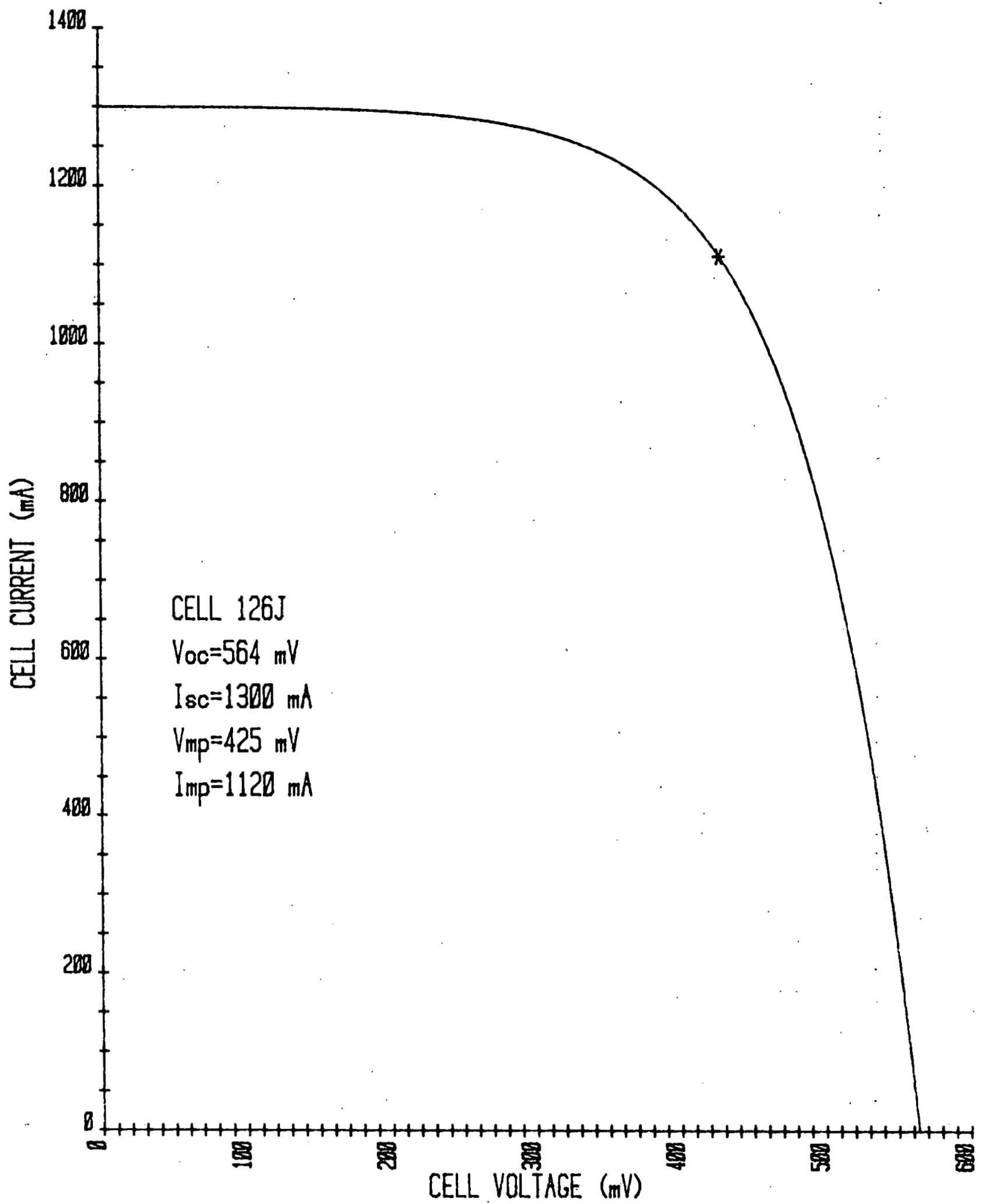

Figure 9. I-V Curve for a 3-inch Diameter Solar Cell Annealed with a Quantronix Nd:YAG Laser Scriber 


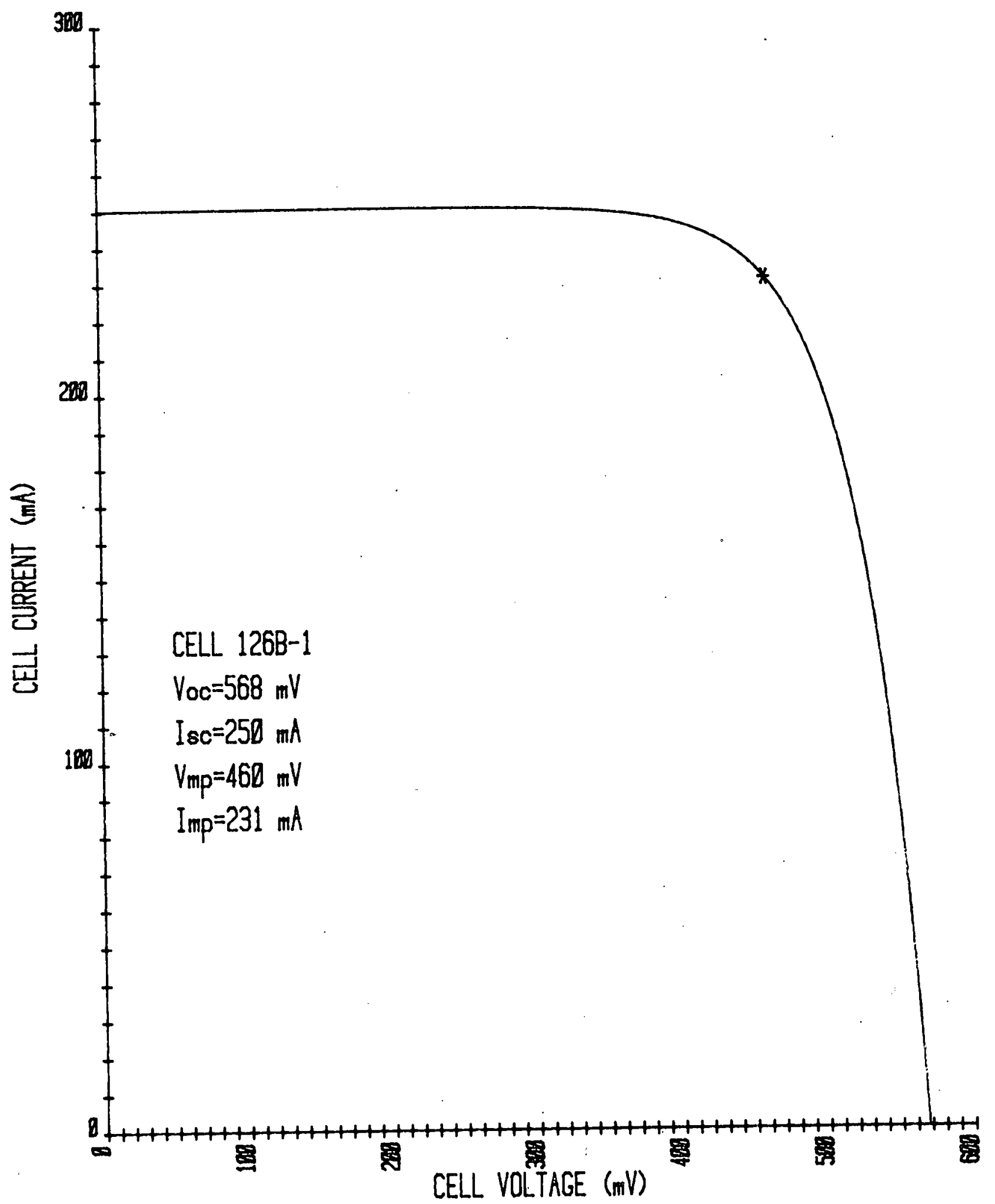

Figure 10. I-V Curve for a $2 \times 4 \mathrm{~cm}$ Cell Annealed with a Quantronix Nd:YAG Laser Scriber 


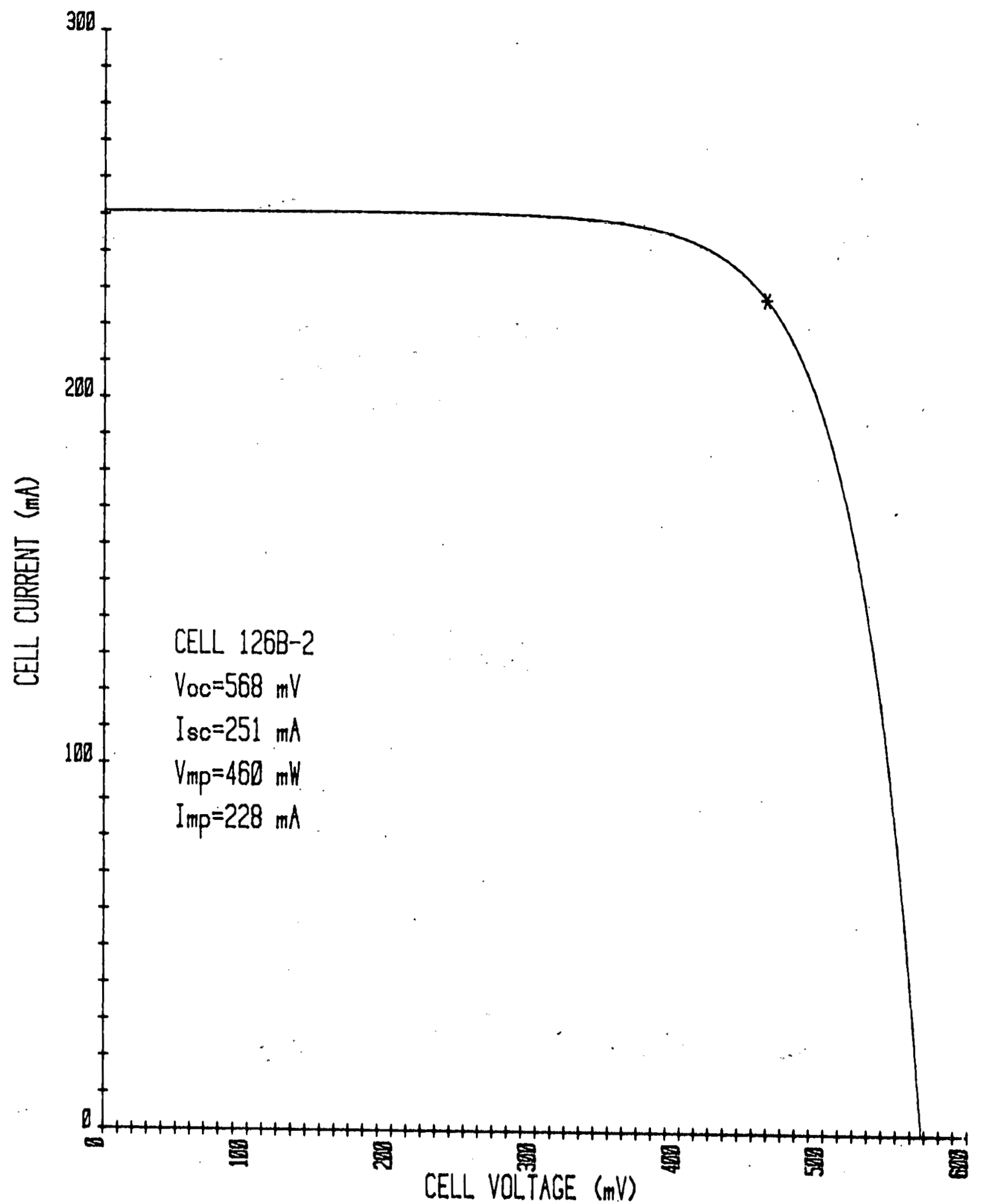

Figure 11. I-V Curve for a $2 \times 4 \mathrm{~cm}$ Cell Annealed with Q Quantronix Nd:YAG Laser Scriber 


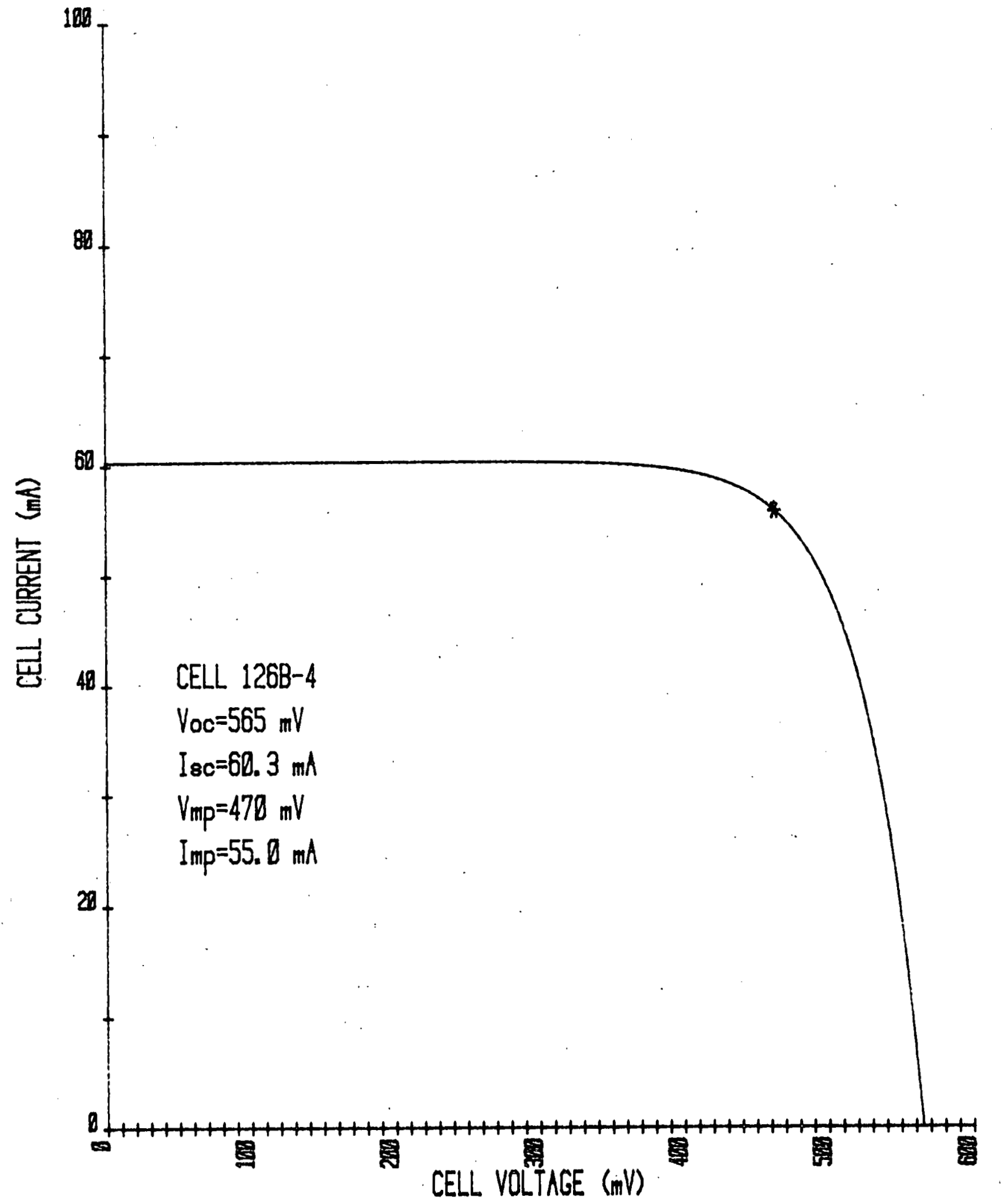

F1gure 12. I-V Curve for a $1 \times 2 \mathrm{~cm}$ Cell Annealed w1th a Quantronix Nd:YAG Leser Scriber 


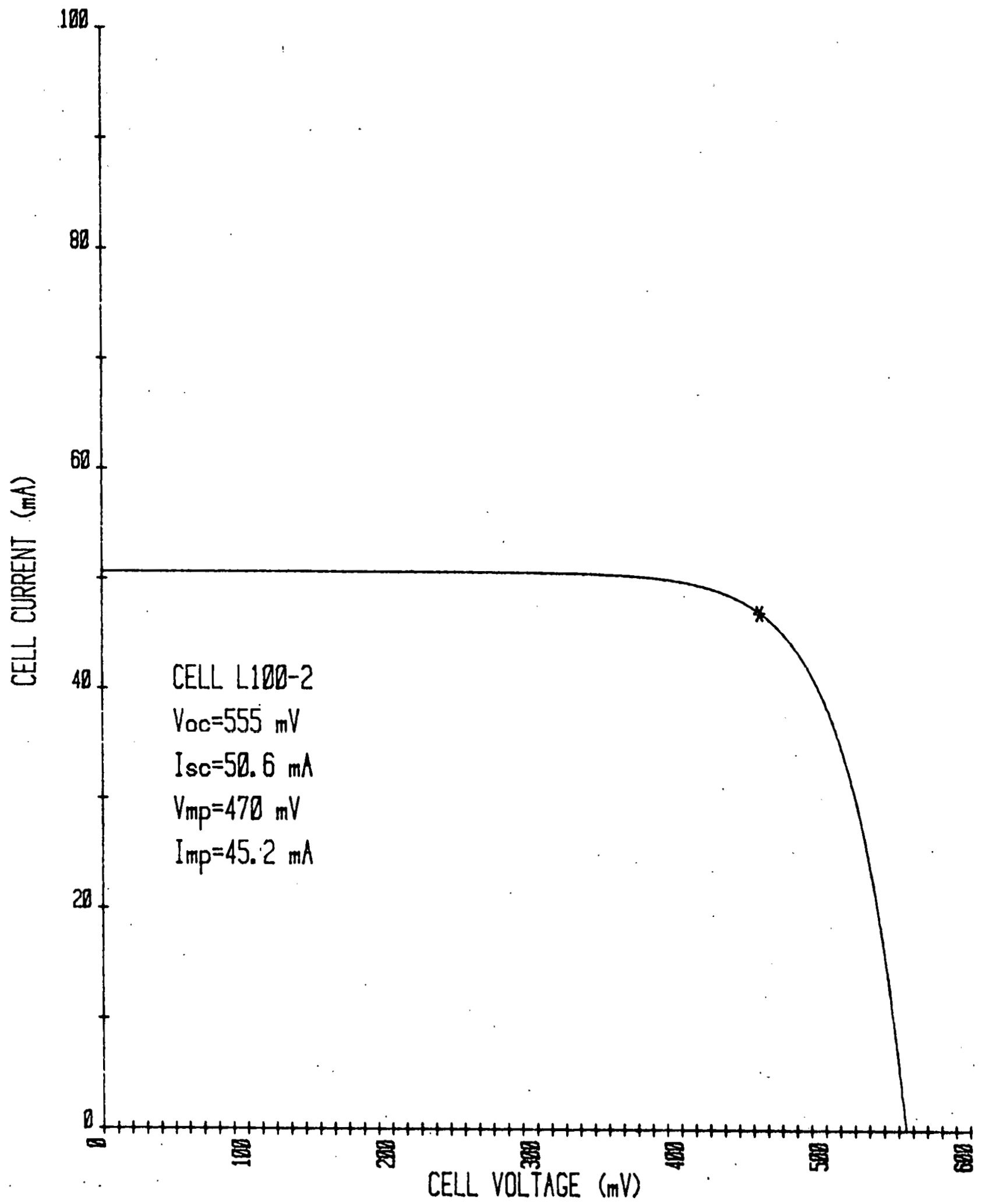

Figure 13. I-V Curve for a $1 \times 1.9 \mathrm{~cm}$ Cell. Annealed with an ESI/Holobeam Nd:YAG Laser Scriber 


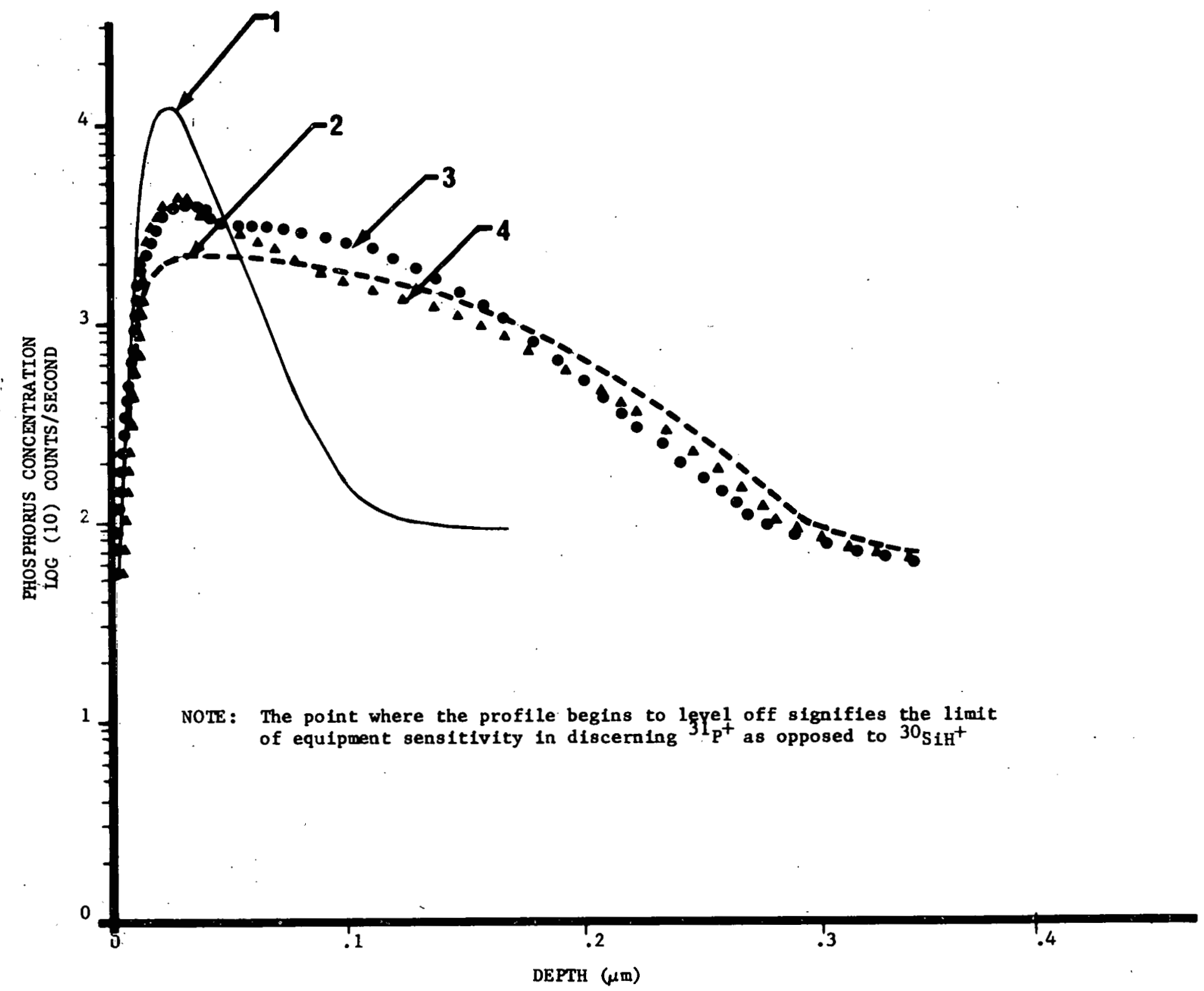

Figure 14. Profiles of the Distribution of Phosphorus Atoms in a Polished Silicon Wafer

(1) - As Implanted $3 \times 10^{15}$ ions $/ \mathrm{cm}^{2}, 25 \mathrm{KeV}$

(2) Ruby Laser Annealed - Korad

(3) ND:YAG Laser Annealed - Quantron ix

(4) $\triangle$ Nd:YAG Laser Annealed - Holobeam 


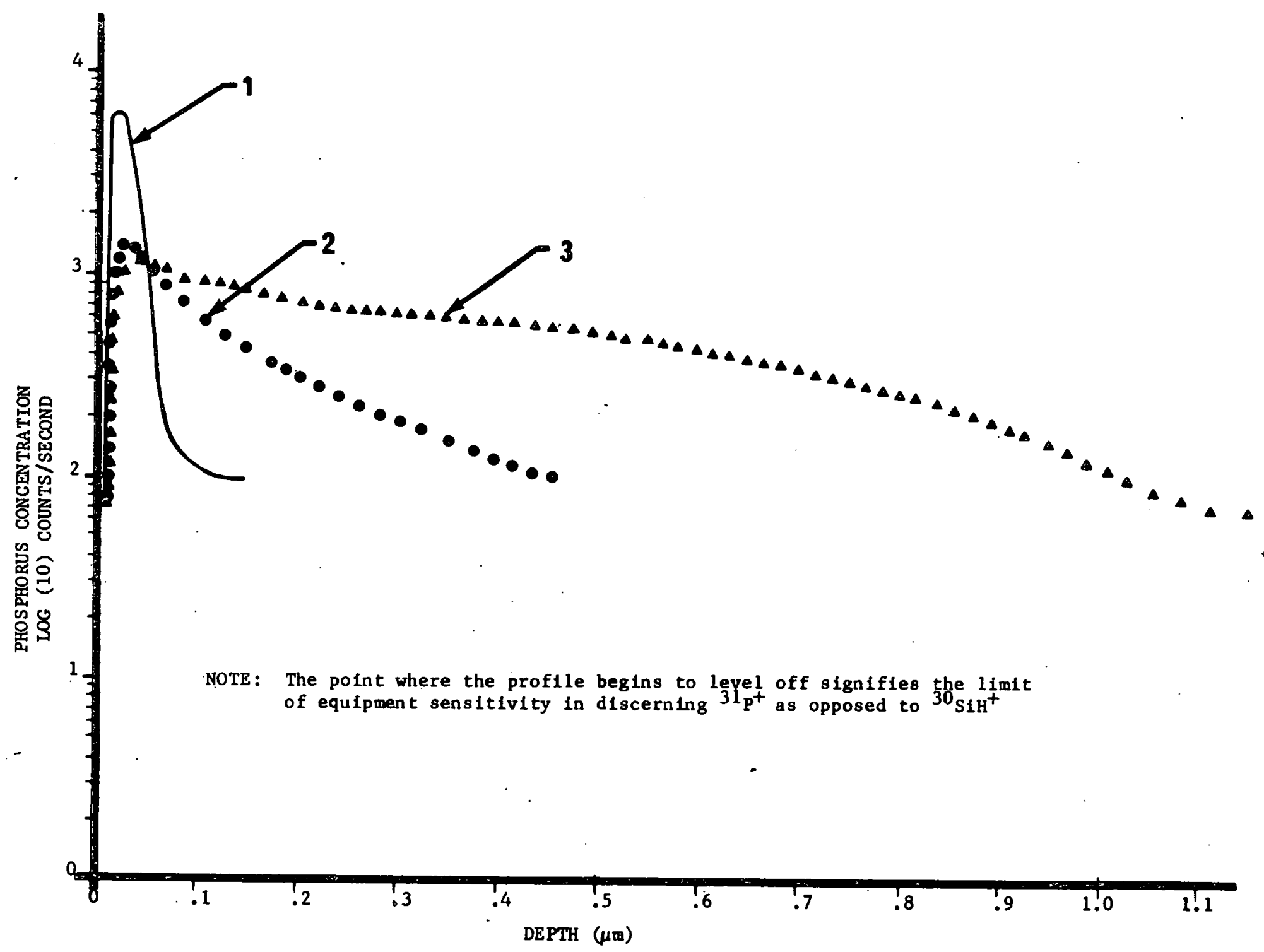

Figure 15. Profiles of the Distribution of Phosphorus Atoms in a Flash-Etched Silicon Wafer

(1) - As Implanted, $2.5 \times 10^{15}$. Ions $/ \mathrm{cm}^{2}, 10 \mathrm{KeV}$

(2) $\infty$ Furnace Annealed $-900^{\circ} \mathrm{C} / 50$ minutes

(3) $\triangle$ Laser Annealed - Holobeam Nd:YAG 


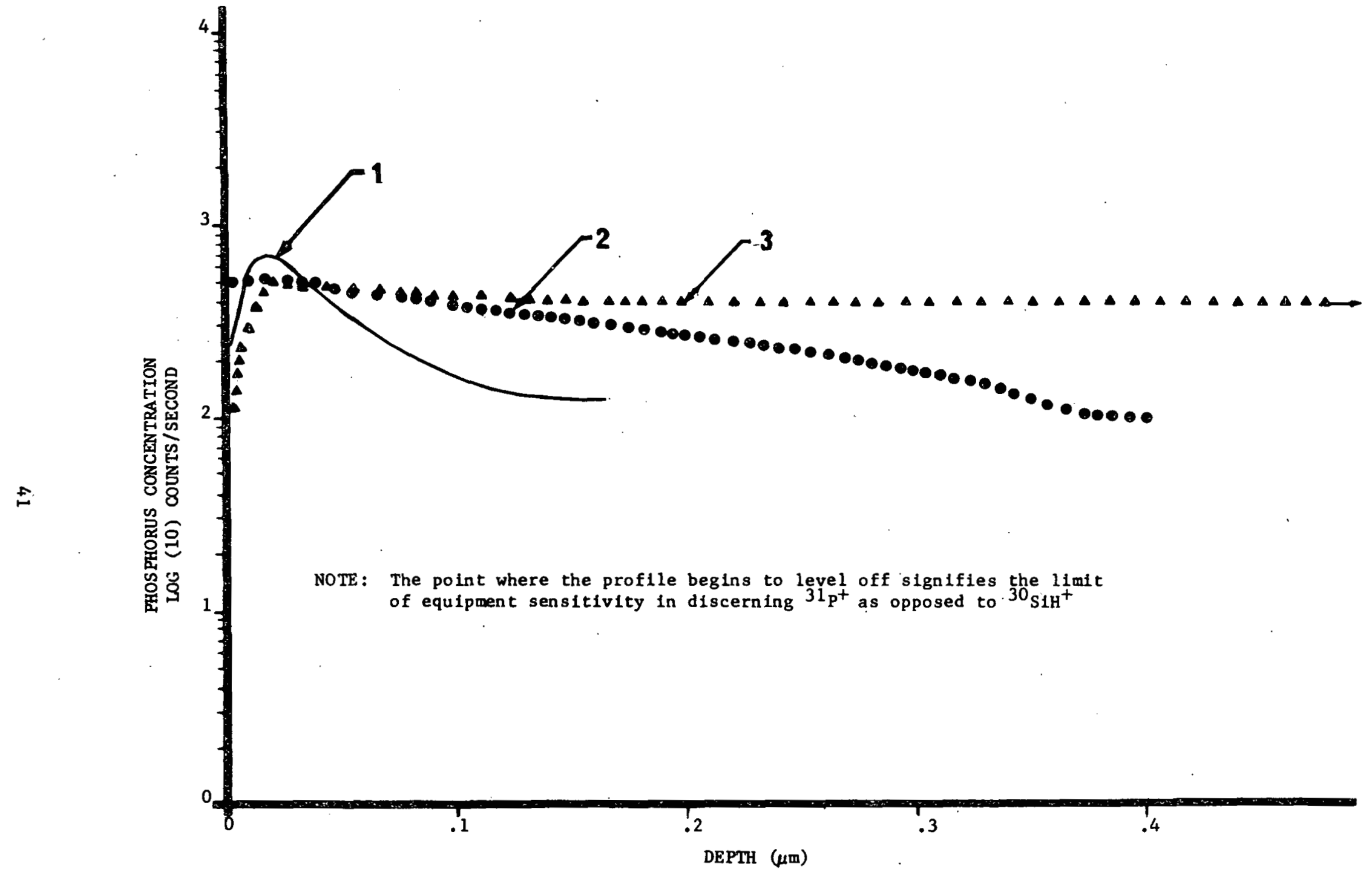

Figure 16. Profiles of the Distribution of Phosphorus Atoms in a Texture-Etched Silicon Wafer

(1) - As Implanted, $3.0 \times 10^{15}$ ions $/ \mathrm{cm}^{2}, 10 \mathrm{KeV}$

(2) Furnace Annealed $-900^{\circ} \mathrm{C} / 50$ minutes

(3) Laser Annealed - Ho! cbeam Nd:YAG 
tion brought about by laser annealing. All four profiles were for phosphorus implants into a polished silicon wafer.

The three laser annealed profiles reflect impurity redistribution associated with annealing with various lasers. Profile 2 appears to be 1deal, being the closest to a flat top distribution. This profile was attained through annealing with a Korad ruby laser with pulse duration of approximately $20 \mathrm{nsec}$. Profiles 3 and 4 were obtained through annealing with Quantronix and ESI/ Holobeam Nd:YAG laser systems, respectively. A number of mechanisms were responsible for the fact that impurity redistribution profile with the Nd:YAG lasers was not as flat as with the ruby laser. The $1064 \mathrm{~nm}$ wavelength of the YAG lasers exhibits deeper penetration into the silicon with subsequent lower temperatures in implanted surface layers. This condition leads to a slower and shallower progression of the melt front and consequently of the impurity atoms as indicated by the higher impurity peaks near the surface of the Nd:YAG-annealed samples as compared to ruby-annealed samples.

For all three samples, the impurities diffuse to a depth of about . $3 \mu \mathrm{m}$. For the Nd:YAG lasers, this is accomplished by higher energy densities and ut1lizing long pulse durations $\left(4.8\right.$ joules $/ \mathrm{cm}^{2}, 95 \mathrm{nsec}$ for Quantronix and 8.6 joules $/ \mathrm{cm}^{2}$, $115 \mathrm{nsec}$ for Holobeam). Also, since step and repeat process with an overlap is utilized, some regions on the wafer are exposed to the laser pulse several times resulting in additional movement of the impurities.

It was previously reported ${ }^{2,4)}$ that following laser annealing, the impurity concentration in the near surface region, as revealed by SIMS analysis, was substantially increased. This phenomenon was not consistently observed in our tested samples. It is important to note that some instability in the sputtering action of the primary beam of the IMMA for up to the first $200 \AA$ on some samples was observed, $1 . e$. , instabllity occurred until 
a crater of sufficient depth was created to stabilize the primary beam. Th1s renders the profile depth distribution data near the surface as somewhat questionable. The instability can be eliminated with adequate preparation of the samples, such as deposition of a thin layer of gold on the surface. Beam instability would then be restricted to the gold layer consequently yielding an improved phosphorus profile. It is recommended that additional evaluations be carried out in this area.

Figure 15 shows the impurity profiles for flash-etched wafers. The implanted wafers were supplied by JPL to LMSC. The wafers were implanted at $10 \mathrm{KeV}$, $2.5 \times 10^{15}$ ions $/ \mathrm{cm}^{2}, 10^{\circ}$ tilt. Profile 1 is as implanted, whereas Profiles 2 and 3 are furnace and laser annealed, respectively. Furnace annealing was carried out at $900^{\circ} \mathrm{C}$ for 50 minutes. Considerable impurity movement is evident on the furnace annealed sample. However, the distribution is such that a fairly sharp peak is still maintained with a rapid impurity concentration drop through a depth of approximately .4 $\mu \mathrm{m}$. The laser annealed samples were again annealed with an ESI/Holobeam laser system. In annealing the samples, the prime requirement was providing JPL with 12 laser-annealed 3-inch diameter wafers. To expedite this job within the time that the subject lasers were avallable, anneal laser.settings had to be modified from what was considered optimum in order to attain wafer annealing within a reasonable time period. To do this, pulse repetition rate was increased from $1 \mathrm{KHz}$ to $12 \mathrm{KHz}$, and power output of the laser was increased correspondingly until annealing was achieved. Increase in the above mentioned parameters also caused an increase in pulse duration to $250 \mathrm{nsec}$. This is not an optional selection but rather one that automatically occurs with changes in power and frequency for laser scribers/trimmers. Pulse duration increase also required an increase in energy density from approximately 8.6 joules $/ \mathrm{cm}^{2}$ to 17 joules $/ \mathrm{cm}^{2}$. It was not anticipated at the time the changes were made that these changes would have a profound effect on the impurity profile. In fact, as later realized, the high energy density/high duration pulses coupled to multiple activation of the same area caused creation of a very deep junction - approximately $1.1 \mu \mathrm{m}$, as indicated by Profile 3. This condition is obviously not desirable and 
consequently an appreciable decrease in efficlency can be expected out of the cells made from these wafers.

The backside of the JPL supplied wafers were boron Implanted at $25 \mathrm{KeV}$, $5 \times 10^{15}$ ions $/ \mathrm{cm}^{2}$. This was followed by furnace annealing at:

$$
\begin{aligned}
& 550^{\circ} \mathrm{C}-2 \text { hours } \mathrm{N}_{2} \text { atmosphere } \\
& 850^{\circ} \mathrm{C}-15 \text { minutes } \\
& 550^{\circ} \mathrm{C}-2 \text { hours }
\end{aligned}
$$

It is our opinion that the performance of cells made from the subject wafers may be compromised in view of bulk sllicon dislocations introduced by the above furnace annealing temperatures. Dislocations will be removed in the Implanted layer through laser annealing; however, in the bulk materlal, the dislocations will remain. As previously discussed, this leads to decrease in the minority carrier lifetime with subsequent decrease in cell efficiency. The laser annealed wafers have been delivered to JPL for subsequent fabrication into solar cells followed by required electrical testing.

Figure 16 shows impurity profiles for texture-etched cells implanted at 25 $\mathrm{KeV}, 3 \times 10^{15}$ Ions $/ \mathrm{cm}^{2}$. The as-implanted peak is lower than what has been observed for polished and flash-etched wafers. This is understandable in view of considerable increase in active surface area in a textured cell brought about by the pyramidal surface structure. This considerably lowers the effective impurity concentration density which is reflected in Profile 1. Profiles 2 and 3 are furnace annealed and laser annealed with parameters identical to those utilized for flash-etched wafers. Again, an extremely broad distribution was obtained for Profile 3, the laser-annealed sample. The profile was obtained to a depth of approximately $.5 \mu \mathrm{m}$ since time did not allow pursuing this to its full depth which is probably similar to the flashetched sample. The furnace-annealed sample is also simllar to the one obtained for flash-etched wafers, except it lacks the h1gh peak due to lower 1mpurity concentration density in the texture-etched surface. 
The margin of error in all of the profiles becomes greater as the distance from the peak center point increases. The level where the ${ }^{31} \mathrm{P}+$ profile appears to reach a stable minimum is probably brought about by contributions from ${ }^{30} \mathrm{SiH}^{+}$. The presence of this constitutes a limiting factor in the equipment detection sensitivity. Nevertheless, generated profiles are Indicative of effects that annealing has on implanted wafers.

\subsubsection{Screen Printed Contacts}

A Precision Systems Company, Model 150, semi-automatic screen printer was used in confunction with 325 mesh stainless steel screens to deposit silver and silver/A1 or silver/B conductive pastes. Two front grid and three back contact pastes were evaluated for screen printing and firing. They were DuPont 7095 silver for front and $7095+2 \%$ aluminum and $4021(\mathrm{Ag}+\mathrm{B})$ for the back and Owens-Illinois 6105 (silver and phosphorus) for front and 6109 (silver and aluminum) for the back.

All pastes screened adequately and no problems were encountered in screeulng the .005-inch conductors in the grid design using our standard screening processes. Further verification of this process technique for depositing conductors is not considered necessary, since adequate equipment is now avallable to meet the program goals. Such reservations as exist, concern only the composition of the pastes, their cost and the proper firing schedule for such pastes as are eventually selected. These reservations are delineated in the following firing discussion.

Some time has been expended in an effort to compare firing techniques of screened-on contacts. Belt furnace firing using presently avallable equipment was consldered to be a cost effective technique easily automated, if practical. This technique was compared to diffusion tube firing. T1tanium sliver ( $\mathrm{T} 1-\mathrm{Ag}$ ) evaporated contacts were used as a control. 
1. Control cells - For control purposes, cells similarly processed as those for the screen printed ohmic contact evaluation were used except that the contacts were formed by vacuum evaporation of $\mathrm{Ti}-\mathrm{Ag}$. Wafer surfaces were flash-etched with junctions formed by $\mathrm{POCL}_{3}$ diffusion. Ti-Ag contacts were deposited using standard positive photoresist and evaporation techniques. The TI was evaporated to a thickness of $200-400 \AA$ and the $\mathrm{Ag}$ then deposited to a thickness of $1000 \AA$ without breaking vacuum and sintered. The Ag was then electroplated to a thickness of $\approx 10,000 \AA$ to assure adequate current carrying capacity.

2. Belt furnace firing - A BTU Engineering, Model VIQ-41-4-36 CRD-41, fourzone, digital control belt furnace was used for this test. Test cells were screened the same for both belt and diffusion tube firing. Fronts and backs were fired both separately and together. A typical profile is shown in Figure 17. Due to the limited nature of this investigation, no final conclusions will be drawn, although it is apparent that within the scope of this investigation, belt furnace firing is not adequate for the pastes evaluated. It is recommended that if further investigation is contemplated, equipment modification (or new equipment) including a high speed belt $\approx 20$ inches/minute and a quartz. furnace liner be considered.

3. Diffusion tube firing - A Thermco Brute, four-inch, digital controlled furnace was used for this test. Initial results using data published in other reports $\left(45\right.$ seconds @ $950^{\circ} \mathrm{C}$ ) resulted in generally poor results due to firing schedule or paste problems or perhaps both. Through consultation and cooperation with Spectro-Lab, who had reported good results with diffusion tube firing, the time and temperature was modified to 20 seconds (a) $690^{\circ} \mathrm{C}$ with improved results. Again, due to the limited scope of this investigation, these improved results have not been further pursued nor optimized since they were deemed adequate for producing cells for subsequent AR-coating tests. It should be pointed out that a new lot of silver paste of the same type (7095) first used was ut1lized in the latter tests.

. None of the pastes performed satisfactorily, although the $6105 / 6109$ combination when fired according to the manufacturer's schedule gave consistently better results than the $7095(7095+\mathrm{A} 1)$ or $7095 / 4021$ combination. 
HUNDREDS OF DEGREES FAHRENHE'

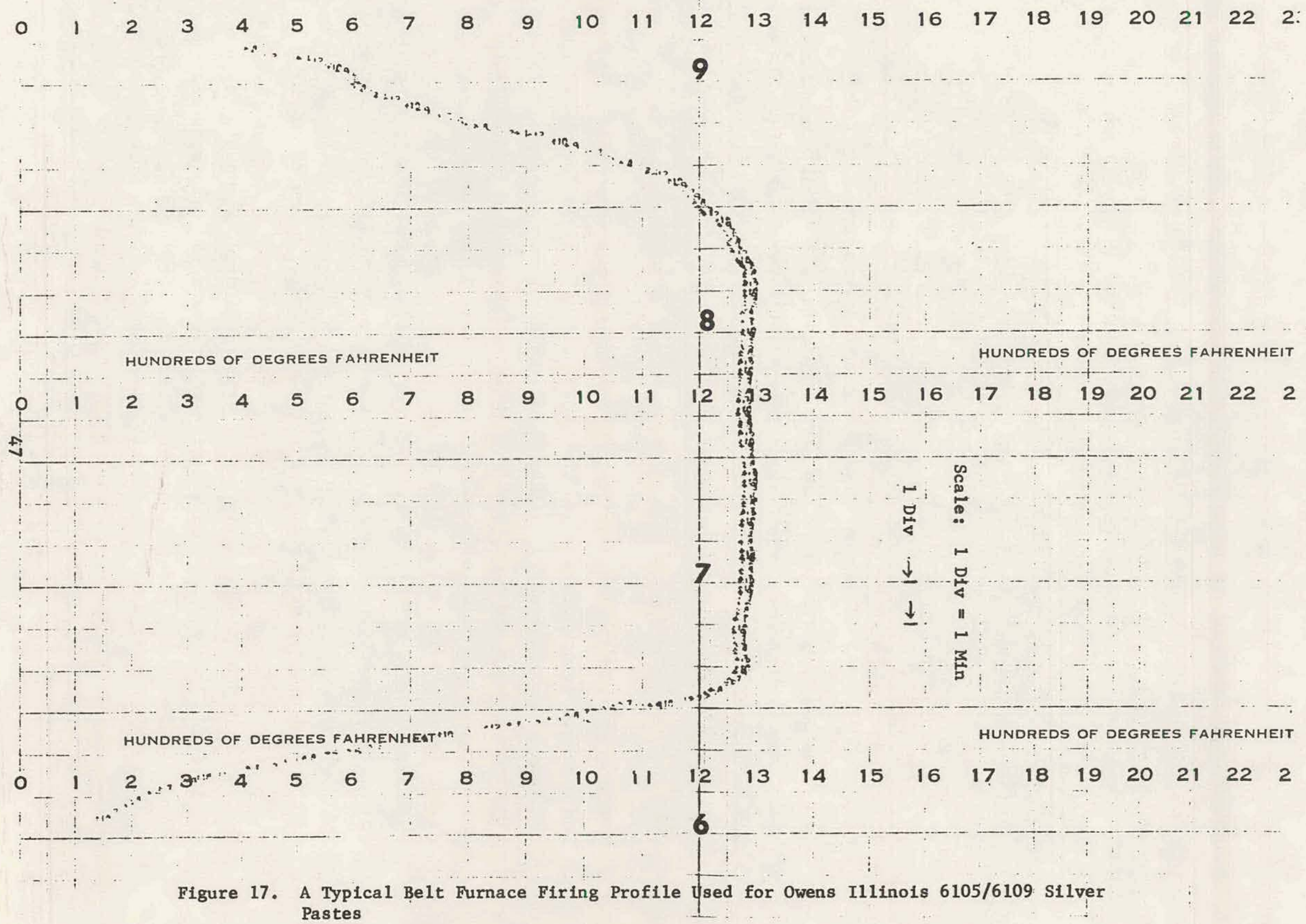


Fill factors for the $6105 / 6109$ combination averaged 52.6, while for the $7095 / 7095+\mathrm{Al}$, the average was only 26.8 . This compares to 65.7 for the control standard.

It is obvious from these results that considerable work must be done on both pastes and firing schedules before this process is satisfactory. Since the process is highly automatable and thus, has a high appeal (and probability) for meeting the goals of this PROJECT, it is recommended that this development work continue.

\subsubsection{Spray-On AR Coating}

Spray coating experimentation was performed using a Zicon Autocoater, Model 10000, manufactured by Zicon Corporation, Mount Vernon, New York. The spray gun is mounted overhead within the spray chamber, with the spray directed downward. The spray gun is automatically traversed, front to back, over a distance of $17^{\prime \prime}$ with a traverse speed variable up to approximately 20 inches/ second, continuously adjustable. A work table with automatic incremental indexing moves the work relative to the spray gun a distance of, 22 inches. The standard spray nozzles and vapor spreaders on this equipment as supplied by $\mathrm{Zicon}$ are configured to deliver a fan-shaped stream of spray on the part. Figure 18 shows a photo of the Zicon equipment used for this evaluation. There are two companion modules which are normally positioned on each side of the spray modules for in-line processing; however, since the primary objective of this effort was to check sprayability of AR coatings relative to thickness and uniformity characteristics, only the spray module was installed and utilized. From this, extrapolation into a fully automated, high volume process was made and reported in Quarterly Report No. 3.

The tantalum pentoxide coating was of primary interest for our spray process evaluation. Accordingly, two tantalum solutions were formulated and supplied by Allied Chemicals, identified as Nos. 201 and 482. The solutions are low viscosity and low solids systems. The 201 was formulated for spray-on and 


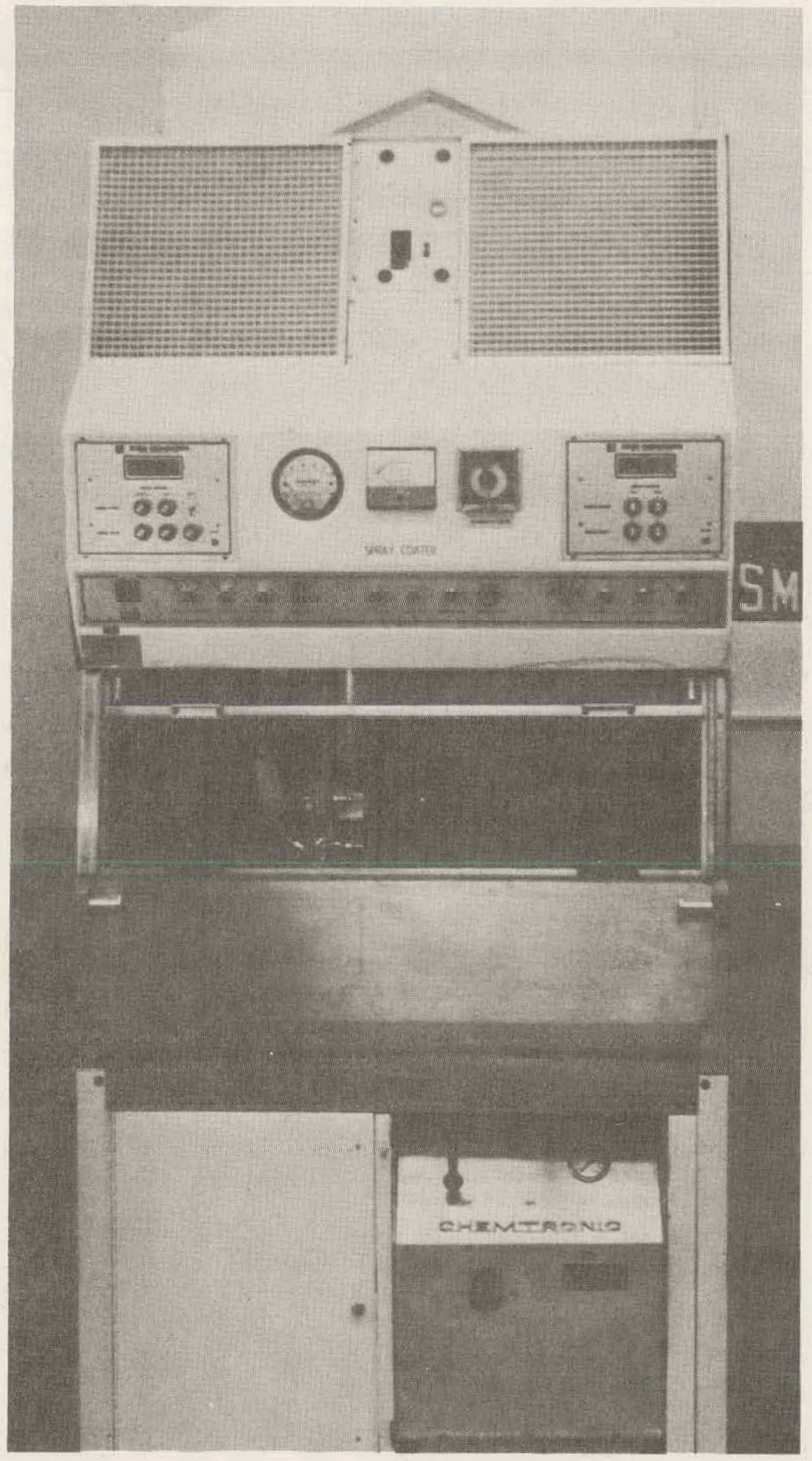

Figure 18. Zicon 10,000 Autocoater - Spray Module 
and the 482 for spin-on. Measured viscosities of the solutions were $2.20 \mathrm{cs}$ for the 201 and $1.96 \mathrm{cs}$ for the 482 , both at $24^{\circ} \mathrm{C}$.

After spraying, the Ta solution is dried at $175^{\circ} \mathrm{C}$ for 2 to 5 minutes to drive off the solvents. Firing in an air conveyor furnace at approximately $500^{\circ} \mathrm{C}$ for 2 minutes at temperature converts the film to $\mathrm{Ta}_{2} \mathrm{O}_{5}$. Extent of drying/ firing temperatures would be governed by trade-offs between cell performance and cost impact.

Initial spraying of the Allied Chemical Ta solutions was performed on polished wafer surfaces using the autocoater. Thickness measurements made using a Gaertner Scientific L117 Ellipsometer resulted in coatings on the 3-inch diameter wafers ranging from $500 \AA$ to $1200 \AA$. Later work resulted in improved uniformity on a $3 / 4 "$ width band of $1100 \AA$ to $1240 \AA$ on chemically-polished cells. Machine settings for these polished cells were as follows:

$\begin{array}{ll}\text { - Number passes } & 1 \\ \text { - Travel rate } & 22 \text { inches/second } \\ \text { - Nozzle height } & 4.25 \text { inches } \\ \text { - Orifice size } & 9 \mathrm{mils} \text { diameter } \\ \text { - Cup pressure } & 2 \mathrm{psi}, \mathrm{N}_{2} \\ \text { - Nozzle pressure } & 40 \mathrm{psi}, \mathrm{N}_{2}\end{array}$

To assess the transmittance qualities of the Ta solutions, they were sprayed on micro slides using the machine settings noted above. Representative transmittance $(T)$ and reflectance (R) curves of glass-coated specimens are shown in Figures 19 through 21. The Ta solutions were applied in the same manner as for those polished silicon wafers used for thickness measurements. A Cary 14 Spectrophotometer was used for these plots. Transmittance and reflectance values (from graphs) at a $.6 \mu$ wavelength are shown as follows: 


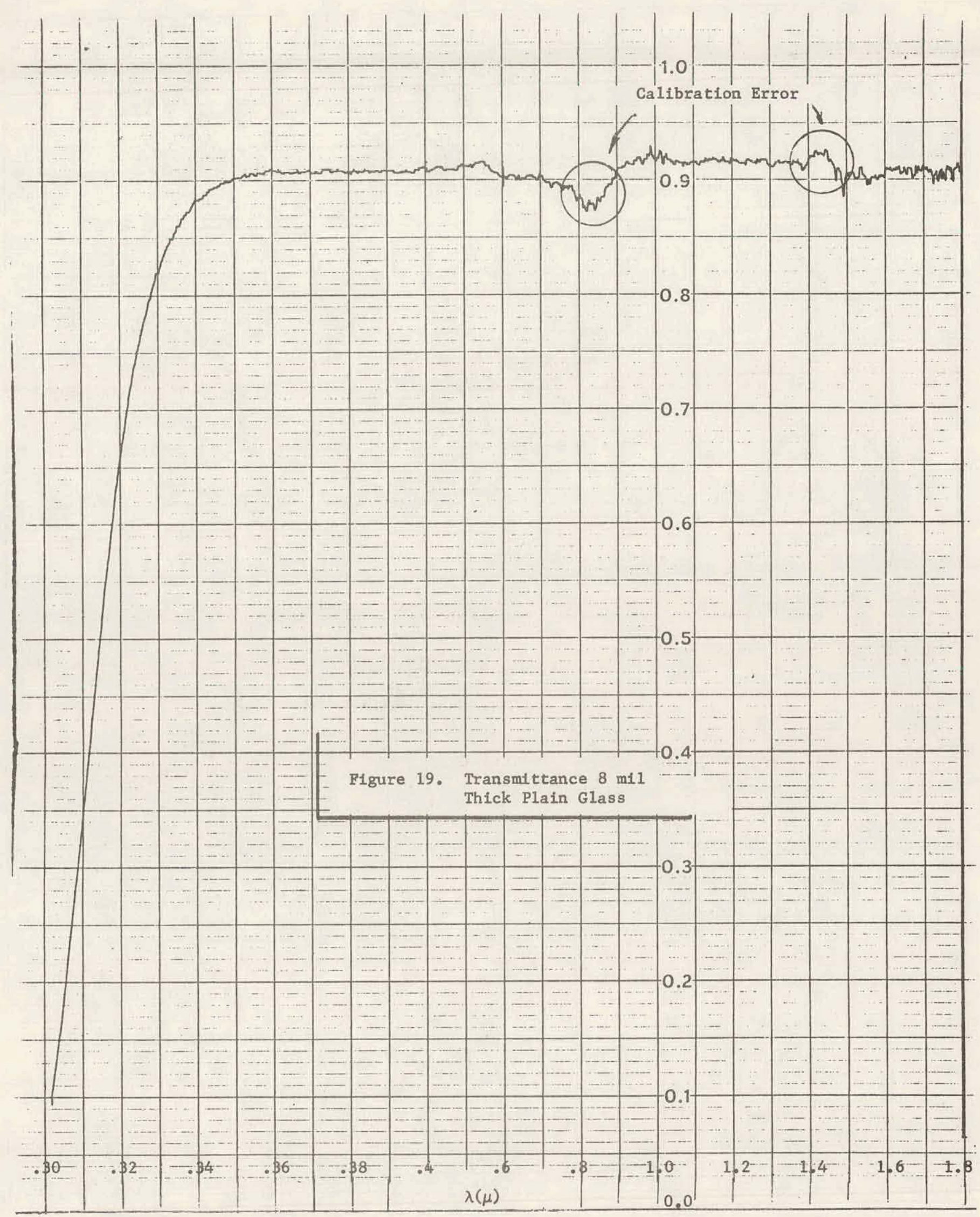




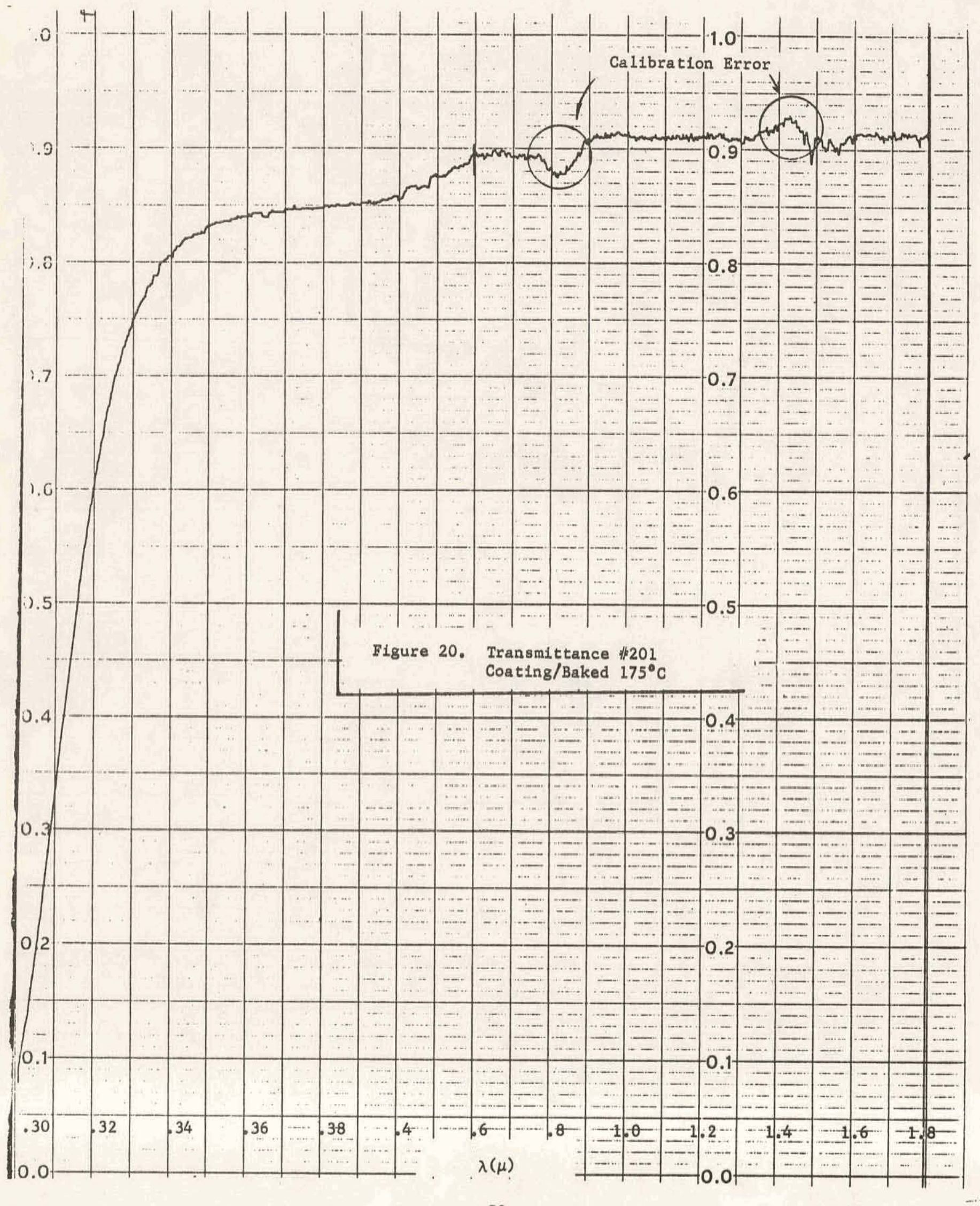




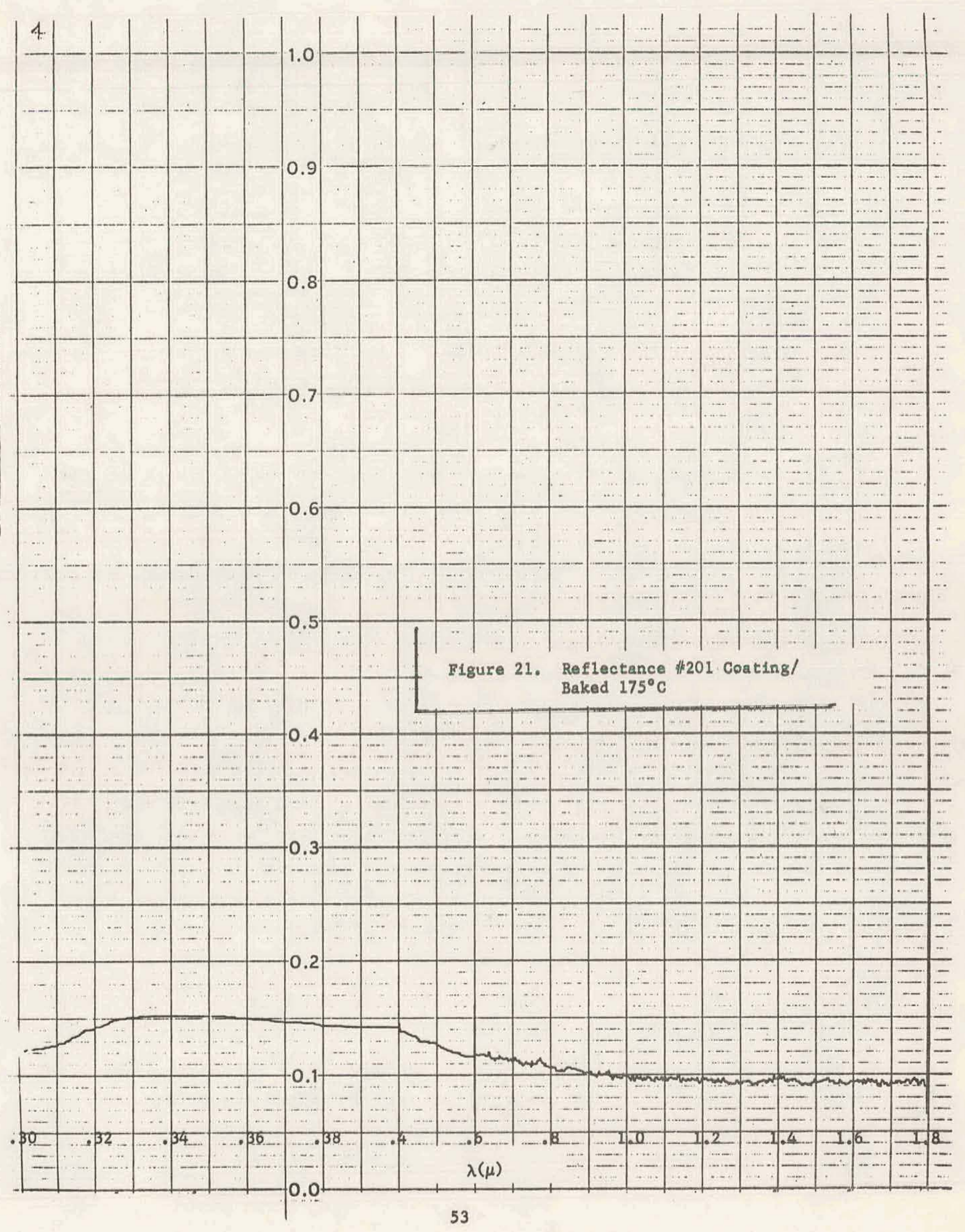




\begin{tabular}{|c|c|c|}
\hline \multirow{2}{*}{ Specimen } & \multicolumn{2}{|c|}{$\lambda=.6 \mu$} \\
\cline { 2 - 3 } & Transmittance & Reflectance \\
\hline 8 mil thick glass (ref) & $90 \%$ & $10 \%$ \\
非01, Baked $175^{\circ} \mathrm{C}$ & $89 \%$ & $11.5 \%$ \\
非201, Fired $500^{\circ} \mathrm{C}$ & $84 \%$ & $18 \%$ \\
非82, Baked $175^{\circ} \mathrm{C}$ & $87 \%$ & $19 \%$ \\
非82, Fired $500^{\circ} \mathrm{C}$ & $85 \%$ & $16.5 \%$ \\
\hline
\end{tabular}

The significance of these $T$ and $R$ values is that they show acceptable values with the low transmission losses after subtracting the plain glass $\mathrm{T}$ value.

Reflectance measurements were also made on a $2 \times 4 \mathrm{~cm}$ chem-polished silicon cel1, before and after spray coated with the 201 material. Figure 22 shows these curves. As can be seen, the reflectance at . $6 \mu$ wavelength, uncoated is $32 \%$, coated is $7 \%$, representing a significant improvement.

Some initial experimentation was performed to determine electrical output effects of these tantalum solutions. Space cells $2 \times 4 \mathrm{~cm}$ in size with chempolished surfaces were used. The cells as-recelved have an SiO coating. Output measurements were made in the as-received condition, followed by stripping of the SiO with buffered HF, retested, coated with the tantalum solutions, and again retested. Coating with the tantalum solution was performed by both spinning and spraying. Spinning is a proven process and over this small area, good thickness uniformity was assured for comparison with the spray-on technique. Tables 3 and 4 show the results of this experimentation for spin-on and spray-on, respectively.

Reasonably good uniformity was attained on the sprayed specimens as evidenced by the light blue coloring across the cell area. The as-sprayed values as shown in Table 4 ranged from $1 \%$ to $6 \%$ lower than the as-received SiO. This could be attributable to the index of refraction differences between SiO and $\mathrm{TaO}$. 


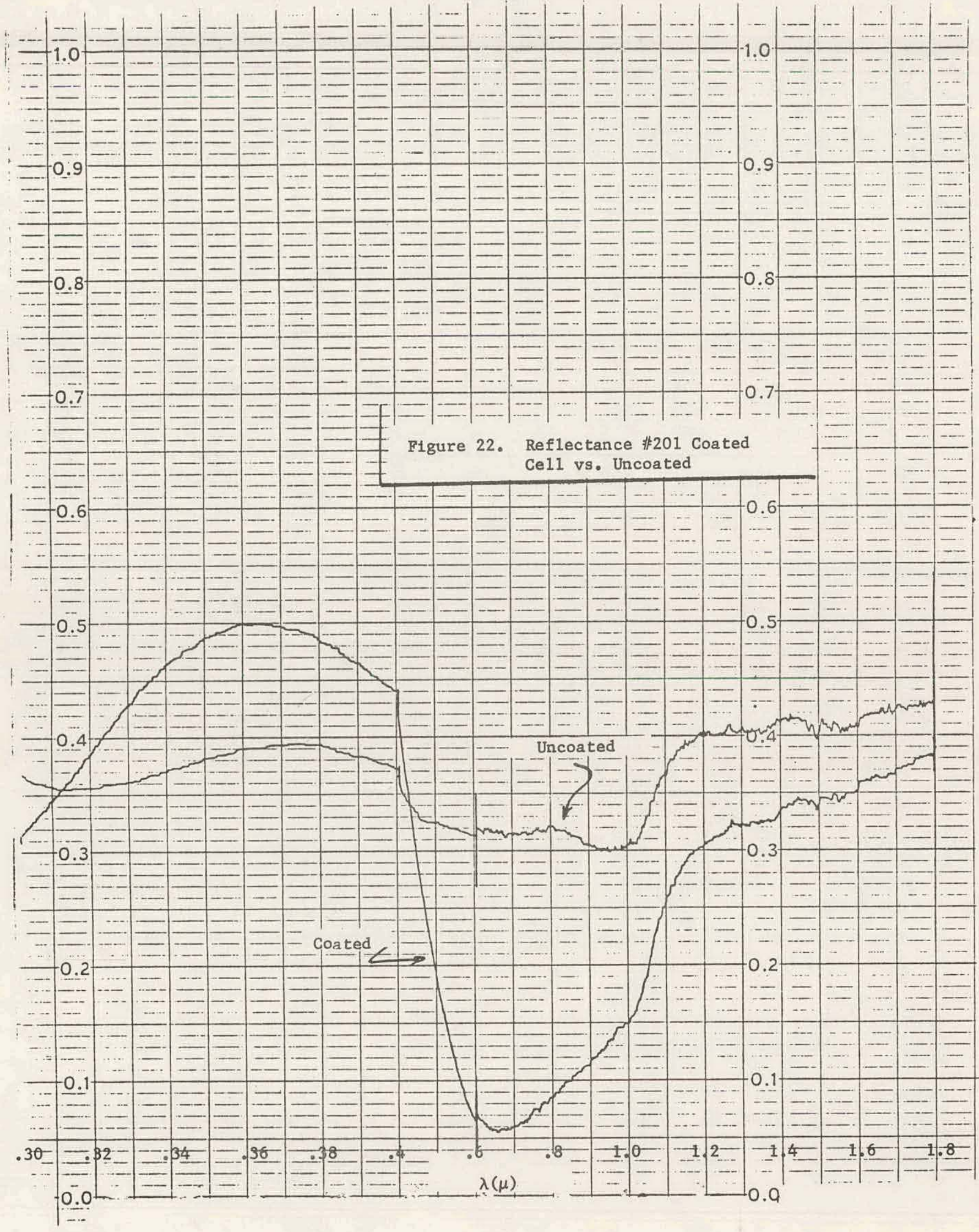


TABLE 3

SPUN-ON Ta SOLUTIONS

Specimen: $2 \times 4 \mathrm{~cm}$ Space Cells with SiO Coat, Chem Polished

Process Parameters: $2000 \mathrm{rpm} / 10 \mathrm{sec}$

\begin{tabular}{|c|c|c|c|c|}
\hline \multirow{2}{*}{$\begin{array}{c}\text { Specimen } \\
\text { No. }\end{array}$} & $\begin{array}{c}\text { Ta } \\
\text { Solution }\end{array}$ & As Received & After SiO Strip & After Coated \\
\cline { 3 - 5 } & & & & \\
\hline & & 273 & 212 & 245 \\
AR 1 & 201 & 267 & 207 & 265 \\
AR 2 & 201 & 270 & 213 & 265 \\
AR 10 & 482 & 269 & 199 & 236 \\
AR 13 & 482 & & & \\
\hline
\end{tabular}

TABLE 4

SPRAY-ON Ta SOLUTIONS

Specimen: $2 \times 4 \mathrm{~cm}$ Space Cells with SiO Coat, Chem Polished

Process Parameters: Zicon Autocoater, 1 pass, 22 inches/second travel, 4.25 inches nozzle Ht, 9 mil orifice, 2 psi source, 40 psi nozzle (both $\mathrm{N}_{2}$ ), baked $175^{\circ} \mathrm{C} / 2$ minutes

\begin{tabular}{|c|c|c|c|c|c|c|c|}
\hline \multirow{2}{*}{$\begin{array}{l}\text { Specimen } \\
\text { No. }\end{array}$} & \multirow{2}{*}{$\begin{array}{l}\mathrm{Ta} \\
\text { Solution }\end{array}$} & \multicolumn{5}{|c|}{ Output $I_{s c}$ (ma) } & \multirow{2}{*}{$\begin{array}{l}\% \text { Increase } \\
\text { From Bare } \\
\text { Cel1 }\end{array}$} \\
\hline & & As-Received & After & SiO & Strip & After Coated & \\
\hline SPR 1 & 482 & 286 & & 215 & & 274 & 27 \\
\hline SPR 2 & 482 & 273 & & 223 & & 257 & 15 \\
\hline SPR 3 & 482 & 275 & & 214 & & 258 & 21 \\
\hline SPR 4 & 482 & 272 & & 221 & & 259 & 17 \\
\hline SPR 5 & 482 & 280 & & 224 & & 262 & 17 \\
\hline SPR 6 & 201 & 283 & & 216 & & 266 & 23 \\
\hline SPR 7 & 201 & 283 & & 219 & & 274 & 25 \\
\hline SPR 8 & 201 & 277 & & 207 & & 268 & 29 \\
\hline SPR 9 & 201 & 290 & & 220 & & 287 & 30 \\
\hline SPR 10 & 201 & 295 & & 222 & & 292 & 31 \\
\hline SPR 11 & 201 & 278 & & 219 & & 271 & 24 \\
\hline
\end{tabular}


Attempts to increase the effective spray pattern to a uniform, one pass, 3inch width proved unsuccessful. Width of spray pattern is generally governed by the distance of the nozzle from the part. Early experimentation in varying the equipment parameters such as nozzle height and pressure, showed best results (most uniform in the $1000 \AA$ range thickness) to be limited to a $3 / 4^{\prime \prime}$ width band. This, then, necessitated multiple passes to coat the 3-inch diameter cells. Final settings for the 3-inch cells consisted of:
- No. work indexing
4
- Table index distance
1.5 inches
- No. spray pass/index
1
- Travel rate
16 inches/second
o- Nozzle height
4.25 inches
o Orifice size
9 mils diameter
- Cup pressure
2 psi, $\mathrm{N}_{2}$
- Nozzle pressure
40 psi, $\mathrm{N}_{2}$

Spray pattern used on these 3 -inch cells is illustrated in the following diagram.

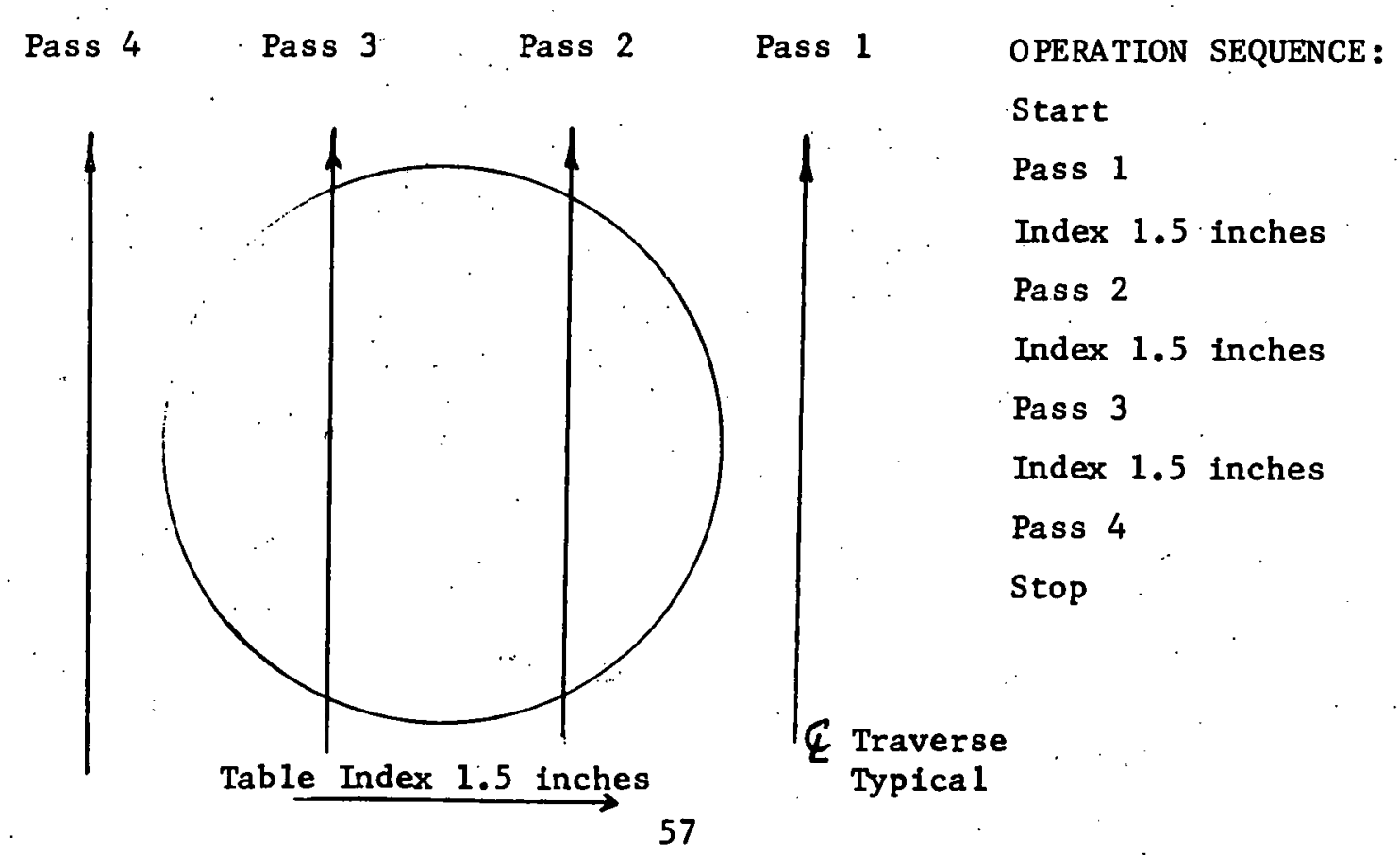


Results of spray coated 3-inch diameter cells are shown in Table 5.

TABLE 5

SPRAY-ON Ta SOLUTION ELECTRICAL OUTPUT EFFECTS - BEFORE AND AFTER

Cell Size: 3 diameter

Process Parameters: Zicon Autocoater

No. Indexing 4

Single Spray Pass/Index

Orifice Size

$9 \mathrm{mils}$

Nozzle Height

Rate

4.25 inches

Spray Material

16 inches/second

A11ied Chem 非201

\begin{tabular}{|c|c|c|c|c|c|c|c|}
\hline \multirow{2}{*}{\multicolumn{2}{|c|}{ Cell No. }} & \multirow{2}{*}{\multicolumn{2}{|c|}{$\begin{array}{l}\text { Surface } \\
\text { Finish }\end{array}$}} & \multirow[b]{2}{*}{ Contacts } & \multicolumn{2}{|c|}{$I_{s c}(A)$} & \multirow[b]{2}{*}{$\Delta \%$} \\
\hline & & & & & $\begin{array}{c}\text { Before } \\
\text { Spray Coat }\end{array}$ & $\begin{array}{c}\text { After } \\
\text { Spray Coat }\end{array}$ & \\
\hline 130 & $\begin{array}{r}C-21 \\
-22 \\
-23\end{array}$ & $\begin{array}{c}\text { Flash Et } \\
" 1\end{array}$ & $\begin{array}{c}\text { Etched } \\
" 1 \\
"\end{array}$ & $\begin{array}{c}\mathrm{Sc}-\mathrm{Pr} \\
" 1 \\
" 1\end{array}$ & $\begin{array}{l}.935 \\
.958 \\
.924\end{array}$ & $\begin{array}{r}1.108 \\
1.051 \\
.978\end{array}$ & $\begin{array}{l}+19 \\
+11 \\
+6\end{array}$ \\
\hline 117 & $\begin{array}{l}-3 \\
-4 \\
-5\end{array}$ & " & $\begin{array}{l}" 1 \\
" 1\end{array}$ & $\begin{array}{c}\text { Electroless } \mathrm{N1} \\
" 1 " \\
" 1\end{array}$ & $\begin{array}{l}.869 \\
.862 \\
.851\end{array}$ & $\begin{array}{l}1.028 \\
1.030 \\
1.024\end{array}$ & $\begin{array}{l}+18 \\
+19 \\
+20\end{array}$ \\
\hline 118 & $\begin{array}{l}-1 \\
-2 \\
-3\end{array}$ & $\begin{array}{l}\text { Texture } \\
\text { " }\end{array}$ & $\begin{array}{c}\text { Etch } \\
" 1 \\
" 1\end{array}$ & $\begin{array}{cc}\text { Electroless } & \mathrm{Ni} \\
" 1 & "\end{array}$ & $\begin{array}{l}1.121 \\
1.123 \\
1.121\end{array}$ & $\begin{array}{l}1.192 \\
1.204 \\
1.200\end{array}$ & $\begin{array}{l}+6 \\
+7 \\
+7\end{array}$ \\
\hline
\end{tabular}

Published data ${ }^{(1)}$ indicates a reflectance $\%$ of $\sim 10 \%$ for texture-etched silicon cell surfaces. After AR coated, this reflectance value is reduced to $\sim 3 \%$, an absorption improvement of $>7 \%$. Relating this $7 \%$ value to increased cell output, it compares favorably with before and after results of textureetched cells shown in the above table.

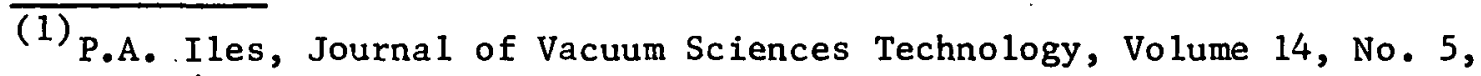
Sept./Oct. 1977 
It is felt that with optimized nozzle and vapor spreader design and dimensional tolerancing, improved performance can be attained with this equipment. Better concentricity of nozzle and vapor spreader parts can improve repeatability. However, the fact that reasonable uniformity was attained with the "as is". equipment lends credence to the merits of this spray technique.

\subsection{HIGH VOLUME PRODUCTION PLAN}

The specific sequence of solar cell manufacturing processes which was the subject of laboratory study in this contract period have been individually extrapolated to the level of high production process and equipment concept definitions. That work has been previously reported in the quarterlies. This sequence of high production processes has now been integrated in to a preliminary plan for a solar cell manufacturing line and is presented in this final report.

The LMSC approach to high production planning favors multiple parallel production lines rather than a single very high throughput system. The rationale for this choice includes several factors: the system can be proven in the first installation which serves as a pilot line; additional lines can reflect incremental process improvements; shutdown of a process step in any one line does not impact the other production lines; shutdown of different process steps on adjacent lines can be accommodated by cross-transfer of parts in process so that the net result is that of one line stopped; a greater degree of flexibility is attained in the establishment of factory production capability; and finally, this arrangement facilitates a hierarchal computer control system for automating the production, with computers at the process, production line, and factory control levels.

The several process steps in cell manufacturing are listed below, together with the production rates anticipated for each. 


\section{Wafers/Minute/Machine}

Texture Etch

Ion Implant

Laser Annea 1

Screen Print

AR Coat
200

$50 \times 3$ machines

$60 \times 3$ machines

150

150
Line Rate/Minute

200

150

180

150

150

The pacing element in this sequence is the ion implant operation, with the laser annealing operation capable of a slightly higher rate. Both of these steps are limited in throughput rate by the nature of the process. The rate for the texture etch process was established before the limitations of the ion implant step were determined, but this process could easily be adjusted to suit. Screen printing and AR coating are probably capable of higher throughput rates but were established to match the ion implant step. The resultant overall production rate for this cell manufacturing 1 ine is 150 cells per minute or 9000 per hour. On this basis, 5 such lines would produce 45,000 cells per hour. At an assumed yield of $95 \%$, the net production is 42,750 cells per hour which is very close to that estimated for a facility producing $40 \%$ of the total 1986 cell requirements.

The proposed layout for the cell processing line is shown in Figure 23. The elements of the line are identified. As noted, the details of the individual production processes have previously been discussed in the quarterlies. This layout introduces the integration of these processes with the special wafer handling and conveyor devices which are capable of being developed into a tota11y automated production system. The flow of wafers through this line is generally self explanatory, but certain features of the layout should be discussed.

It is assumed that the wafers will be loaded into cassettes by the wafer supplier. These are specially configured with an open frame to facilitate their use as a carrier through the texture etch process. They are also used for in line storage of wafers to supply the ion implant process. The empty cas- 


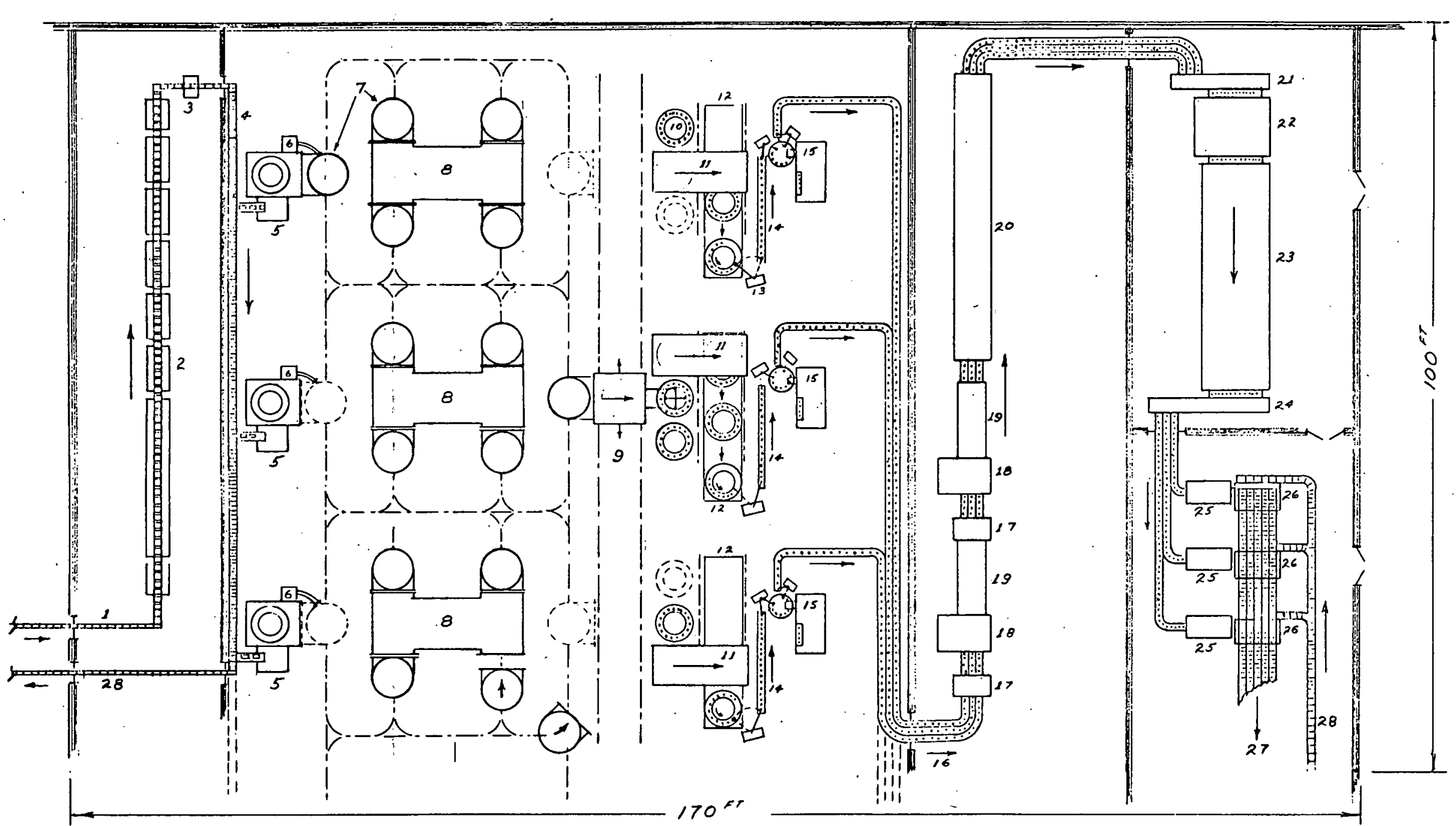

SOLAR CELL MAMUFACTURING LINE
LEGEND:

I. LOADED CASSETES FROM WAFERCO ON CONVEYOR

2. TEXTIRE ETCH PROCESS

3. INSPECTION STATION

4. MULTILVEEL CASSETE STORAGE - STOCK FLOAT FOR ION IMPLANT

5. TRANSFER WAFERS FROM CASSETTES TO TRAYS - CASSETES RETURN TO EXIT CONVEYOR - EMPTY

6. VACUUM SOURCE FOR PUMP DOWN OF CHAMBER AFTR LOADINC

7. MOBILE VACUUM CHAMBERS - FIVE PROVIDED FOR EACH ION IMPLANT STATION

8. ION IMPLANT STATION

9. UNLOAD TRAYS FROM CHAMBERS AND STACK - TRACK GUIDED TRAVEL TO THREE POSIIIIONS FOR

10. TRAY STACK ON ElLVATOR PLATform RECESSED IN FLOOR - STOCK FLOAT FOR LASER ANNEAL

11. TRANSFR TRAYS FROM STACK TO TRAY UNLOADER - TRACK GUIDED TRAVEL TO THREE

12. TRAY INOEX TABLE AT END OF TRAY UNLOADER - TRAYS RETURNED TO $S$ BY ELEVATOR AND

TRANSFR WAFERS FROM TRAYS TO CONVEYOR

14. STORAGE CONVEYOR WITH "PICK \& PLACE" ARM TO UNLOAD

15. LASER WITH INDEXING TURNABBLE - STATIONS FOR WAFR POSITIONING USER ANNEALING,

b. parauel matra conveyors

16. PARALG WATER CONVYYORS

17. WAFER TURNOVER STATIONS

18. SCREEN PRINT STAIIONS

19. BAKE OVEN CONVEYOR

20. FURNACE CONVEYOR

21. REPOSITION WAFERS IN ROWS OF B

22. SPRAY AR COAT

23. BAKE AR COAT

24. REPOSITION CELLS IN ROWS OF THRE

25. CELL TEST STATIONS

26. SORT CELLS AND LOAD IN CASSETTES - TRANSFER CASSETTES TO OVERHEAO CONVEYOR

27. OVERHEAD CASSETI CONVEYOR TO FINISHED STORES

28. EMPTY CASSETTE CONVEYORS

- PRODUCTION RATE - 9000 Cells per hour

- FIVE LINES REOUIRED FOR PLANT PRODUCING $40 \%$ OF 1986 PRODUCTION REOUIREMENTS

Figure 23 
settes are carried by conveyor to the receiving area for return to the wafer source. The texture etch process requires storage tanks for preheating, filtration, solution makeup, etc. These are intended for installation at the basement level directly below the processing tanks so that this portion of the system maintenance operations are separated from the production area. The high voltage ion beam source is also located in the basement for maintenance and safety as well as satisfaction of the proposed equipment configuration. Certain portions of both the cassette and wafer conveyor lines are expected to be elevated to provide clearance for pedestrian walkways. These locations should be at the cassette entrance and exit conveyors in the texture etch room, at the wafer conveyors leaving the laser anneal stations and entering the screen print room, and for the empty cassette conveyor(s) which supply the final test and sort operations.

The flow of wafers through the several operations is arranged to facilitate extensions of the cassette and wafer conveyors and of the vacuum chamber guide tracks associated with the ion implant process. This will permit crosstransfer of work pieces to an adjacent production line to assist in minimizing the impact of down time for individual processes. It should also be noted that the separate rooms, provided to control cross-contamination between processes, can be extended in length to accommodate additional parallel production lines.

\subsection{PROCESS PROCEDURES}

Detailed process procedures were prepared and submitted to JPL. They reflect the step-by-step process used in the fabrication of hardware for our process verification evaluations. Processing procedures included: texture-etching, ion implantation, laser annealing, screen printed ohmic contacts, and sprayed AR coatings. 
3.6 SAMICS

Solar Array Manufacturing Industry Costing Standards, Format A's for our solar cell process sequence were prepared and are included in Appendix A as follows:

Process Description

Texturize Etch

Ion Implant

Laser Anneal

Screen Printing

AR Spray Coat
Page

A-1

A-13

$A-18$

A-24

$\therefore \quad A-30$ 
Section 4

CONCLUSIONS

4.1 Texture etching of 1:0:0 Cz silicon wafers without an initial flash etch step yields acceptably prepared surfaces for standard processing, such as with furnace annealing of ion-implanted cells.

4.2 A dedicated $10 \mathrm{~mA}$ beam current ion implanter with an acceleration voltage 5 to $10 \mathrm{KeV}$ will satisfy the high throughput requirements of the 1986 PROJECT goals.

4.3 Laser annealing has been demonstrated to yield high efficiency output ion-implanted cells.

4.4 Laser annealing offers excellent prospects to achieve the low cost objectives through its high throughput and reduced energy consumption potentials. High powered glass lasers are available with the capability of ylelding pulsed spot sizes on the order of 3-inch diameters.

4.5 Lasers best sulted for annealing of silicon wafers for this LSA PROJECT are pulsed Q-switched, Nd:Glass and Nd:Glass with a frequency doubler. The wavelenghts of these lasers are: $1064 \mathrm{~nm}$ and $532 \mathrm{~nm}$, respectively. Comparable lasers in the high frequency, low power categories are not compatible with the high throughput requirements of the PROJECT. This includes ruby and argon CW or pulsed lasers.

4.6 Laser annealing yields a substrate from which higher efficiency cells can be fabricated than those fumace annealed at a conventional 30 minute, single step cycle.

4.7 Laser annealing with Q-switched lasers result in surface melting and therefore, does not appear to be compatible with texture-etched silicon 
wafers. However, used with flash-etched and AR spray-coated techniques, additional processing costs could be saved with no loss in cell efficiencies.

4.8 Silver paste material costs to form screen-printed ohmic contacts will not meet the PROJECT cost objectives unless techniques are developed which reduce the amounts utilized. Alternate materials and processes could contribute significantly.

4.9 Semi-automated spray coating of AR film has been demonstrated to show excellent potential for high throughput, low cost manufacturing. However, nozzle and vapor spreader optimization is required for improved performance.

4.10 Low cost, high throughputs of the various process steps of texture etching, ion implanting, laser annealing, screen printing and sprayed AR coatings can be attained to meet the 1986 LSA PROJECT goals based on our automated high volume production plan. 


\section{Section 5}

RECOMMENDATIONS

5.1 Scale-up the laser annealing verification work using a Q-switched glass laser system capable of single pulse annealing of at least 1inch diameter spot size. From this work, more concrete determinations can be made for scale-up to high powered lasers with 3-inch diameter spot sizes and rep rates of 1 pps.

5.2 Verification work on alternate high throughput, low cost, ohmic contacting systems should be continued.

5.3 Spray coating of AR film should be optimized by developing more precision nozzles and vapor spreader mechanisms to accommodate larger width, uniform patterns ( 3 inches). 
REFERENCES

1. Physical and Electrical Properties of Laser Annealed Ion-Implanted Silicon/ A. Gat, J. F. Gibbors - Stanford Electronics Laboratories, Stanford, Ca., App1. Phys. Lett. Vol., 32, p. 142 (1978)

2. Laser Annealed Boron Implanted Silicon Solar Cells/R. T. Young, C. W. White, G. J. Clark, J. Narayan, R. D. Westbrook, W. H. Christie - Oak Ridge National Laboratories, Oak Ridge, Tenn., Proceedings of the Photovoltaic Solar Energy Conference, Luxembourg (Sept 27-30, 1977)

3. Laser Annealing of Implanted Silicon/O. G. Kutukova, L. N. Streltsov I. V. Kurchatov Institute of Atomic Energy, Moscow, U.S.S.R., Sov. Phys. Semicond. Vol. 10, No. 3 (Mar 1976)

4. Distribution of an Implanted Impurity in Silicon After Laser Annealing/ A. Kh. Antonenko, N. N. Gerasimenko, A. V. Dvurechenskii, L. S. Smirnov, G. M. Tseitlin - In'stitute of Semiconductor Physics, Academy of Sciences of the U.S.S.R., Novosibirsk, Sov. Phys. Semicond., Vol. 10, No. I (Jan 1976)

5. Annealing of Implanted Layers by a Scanning Laser Beam/G. A. Kachurin, G. V. Nidaev, A. V. Khodyachikh, L. A. Koraleva - Institute of Semiconductor Physics, Siberian Branch, Academy of Sciences of the U.S.S.R., Novosibirsk, Sov. Phys. Semicond., Vol. 10 (Oct 1976) 
APPENDIX A

SOLAR ARRAY MANUFACTURING INDUSTRY

COSTING STANDARDS (SAMICS)

FORMAT A'S

A 


\section{SOLAR ARRAY MANUFACTURING INDUSTRY COSTING STANDARDS}

FORMAT A

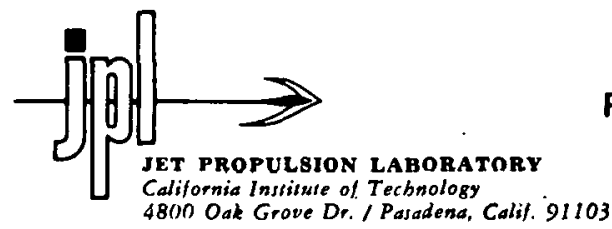

PROCESS DESCRIPTION

A1 Process Referent Tex Etch Revision A. 6/29/78

A2 Description (Optional) Texturize Etch, Rinse and Dry

PART 1 - PRODUCT DESCRIPTION

A3 Product Referent $\quad$ TE Wafer
A4 Name or Description Texture Etched Wafers

A5 Units Of Measure Wafers

PART 2 - PROCESS CHARACTERISTICS
A6 Output Rate
200
Units (given on line A5) Per Qperating Minute
A7 Average Time at Station
40
Calendar Minutes
A8 Process Usage Time Fraction .976
Average Number of Operating Minutes Per Minute

PART 3 - EQUIPMENT COST FACTORS

A9 Component Referent

A10 Base Price Year For Purchase Price

1977

A11 Purchase Price (\$ Per Component)

A12 Anticipated Useful Life (Years)

A13 Salvage Value (\$ Per Component)

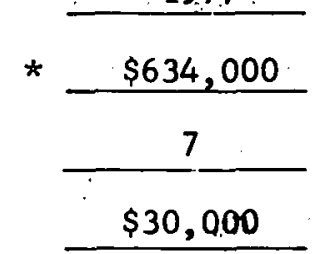

A14 Cost of Removal \& Installation (\$/Component) ${ }^{* *} \$ 83,000$

$*_{\mathrm{A}-11}$ includes on-site assembly and installation costs of $\$ 83,000$ due to the configuration of this wet process equipment.

**A-14 Removal and installation taken at same level as original installation. Cost of removal assumed to be offset by reuse of some portion of installation, e.g.; roof penetrations, safety sumps, electrical plumbing, etc.

(A) Note: See also Appendix to Format A - Texture Etch for additiona JPL 3037-S $11 / 77$ in formation. 
Format A: Process Description (Continued)

A14 Process Referent (From Page 1) Tex Etch

PART 4 - DIRECT REQUIREMENTS PER MACHINE

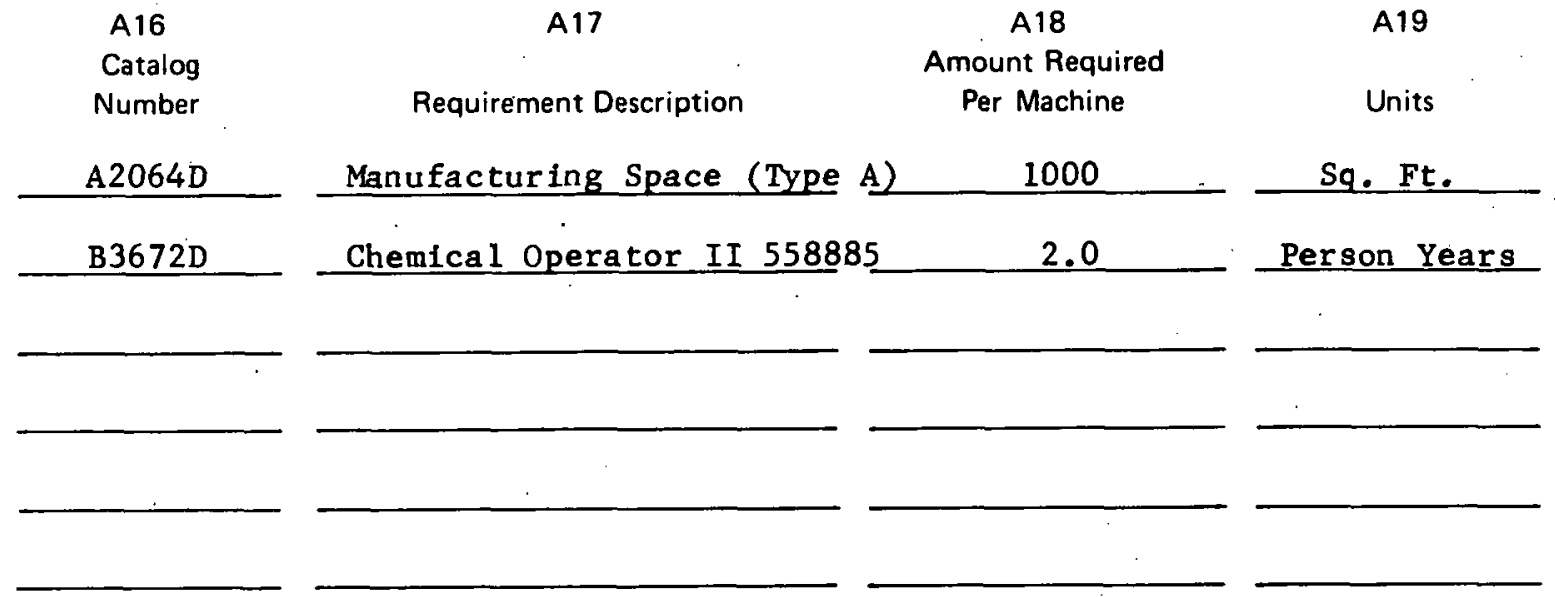

PART 5 - DIRECT REQUIREMENTS PER BATCH (A continuous process has a "batch" of one unit)

A20

Catalog

Number

\begin{tabular}{|c|c|}
\hline & Alcohol \\
\hline & $\mathrm{NaOH}$ \\
\hline \multirow[t]{2}{*}{ C $1016 \mathrm{~B}$} & Tap Water \\
\hline & $\mathrm{H}_{2} \mathrm{~S}_{0_{4}}$ Acid \\
\hline \multirow[t]{2}{*}{ C $1144 \mathrm{D}$} & DI Water \\
\hline & Freon \\
\hline C $1032 \mathrm{~B}$ & Electricity \\
\hline
\end{tabular}

PART 6 - INTRA-INDUSTRY PRODUCT(S) REQUIRED
A22

Amount Required

Per Batch

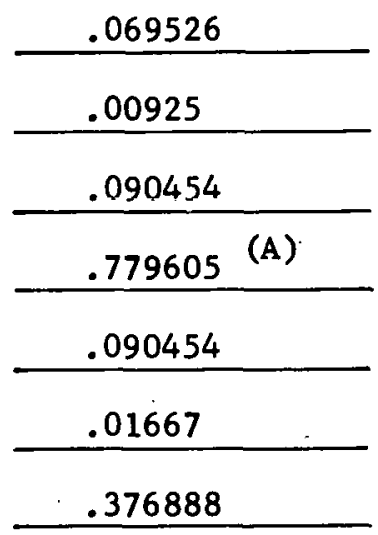

A23

Units Ga 1/Minute Lbs/Minute Ga 1/Minute Lbs/Minute Cu Ft/Minute Gal/Minute KW hr/Minute

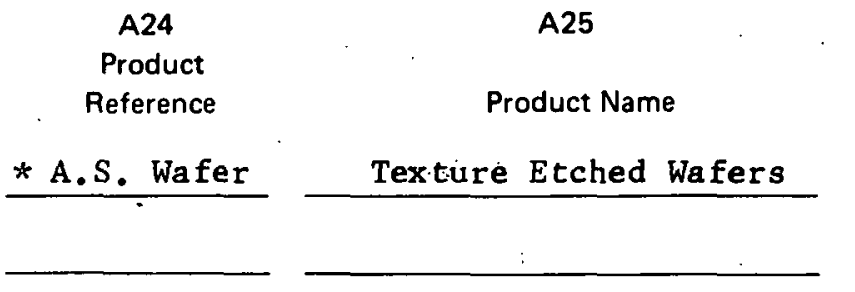

Prepared by R. Casey

$\begin{array}{cc}\text { A26 } & \text { A27 } \\ \text { Yield Factor } & \\ \text { (Usable Output/Input) } & \text { Units }\end{array}$

$* * 99.2 \%$
*As Sawn Wafer

* No inspection is planned at completion of this operation - Figure represents average yield for each of seven process stops with final inspection yield of $95 \%$. 
APPENDIX TO FORMAT $\Lambda$ - TEXTURE ETCI

Prepared by R. J. Casey, LMSC

$6 / 29 / 78$

This material is provided as back-up to SAMICS input as part of JPL.contract 954898 and includes the following:

- A description of the texture etch process (excerpted from Monthly Report No. 6)

- Explanation of the Format $A$ inputs by part and item

- Equipment cost estimating sheets (by LMSC Plant Engineering)

\subsection{HIGH VOLUME PRODUCTION}

\subsection{Texture Etch Process}

The basic process specification for texture etching of silicon wafers was provided to IMSC (IR) by JPL. Some adjustments to procedural detalls were made to improve our results in processing of wafers during the early portion of this contract. This modifled process has been extrapolated to a large scale automatic etching system as would be required for 1986 production quantities. .

The hydrogen peroxide neutralizing rinse has been eliminated in our projected process, as we believe that the simpler acld rinse will suffice if followed by multiple DI water sprays. The system defined here is configured for pllot evaluation. In this regard, it provides for excess capability in terms of sodium hydroxide concentration, imersion time and/or processing temperature. Optimum process parameters for an automated system must necessarily be established during a period of trial operation of the actual system. It will

$$
-10-
$$


be simpler at that time to reduce the value of one or more of the variables than to effect an increase. Impact of this approach on overall cost estimates is minlmal. Provislons necessary to minimize downtime and maintain real time process control have been consldered.

The large number of wafers to be run through a wet system argues convincingly for processing of the work pieces while they are held in cassettes. Accordingly, we have defined a special open frame cassette configuration for wet processing. The 3/16-inch wafer spacing is retalned but the length is increased to approximately twelve inches to hold a quantity of 50 wafers. The cassettes are assumed to be loaded by Waferco and entered directly into the Cellco production sequence at this texture etch station. They are automatically clamped to holding devices attached on 6-inch centers to dual conveyor chains which carry the cassettes through the etching steps. Conveyor speed is assumed at 2 feet per minute. Masking of the wafers by the cassette retaining slots is avoided by a technique proven by the Siltec Corporation, Cassette Etch Station, Model 2001, where the cassette is slowly rotated on an eccentric longltudinal centerline. This causes the wafers to move back and forth in their retaining slots, exposing the entire surface to the processing liquids. In this application, the rotation is achleved by spur gears on the end(s) of the cassette holders. The gears engage stationary gear racks as the conveyor chain moves. The conveyor path and the several process steps are. shown schematically in Figure 2.

The first step in the etching process is an alcohol rinse, agttated by submerged jets to direct the flow between the wafers. Vapors are recondensed and retumed to a reservolr which provides makeup alcohol. Cassettes are then carried directly into the etchant tank and through the hot, two percent sodium hydroxide solution. Agitation is similarly provided. Level, pH, temperature and specific gravity sensors control the makeup system. The solution is circulated in reverse flow direction and filtration is accomplished by De-Laval centrifuges which do not require consumable filters or labor intenstve servicing. Vapors may be allowed to vent to the atmosphere carry- 


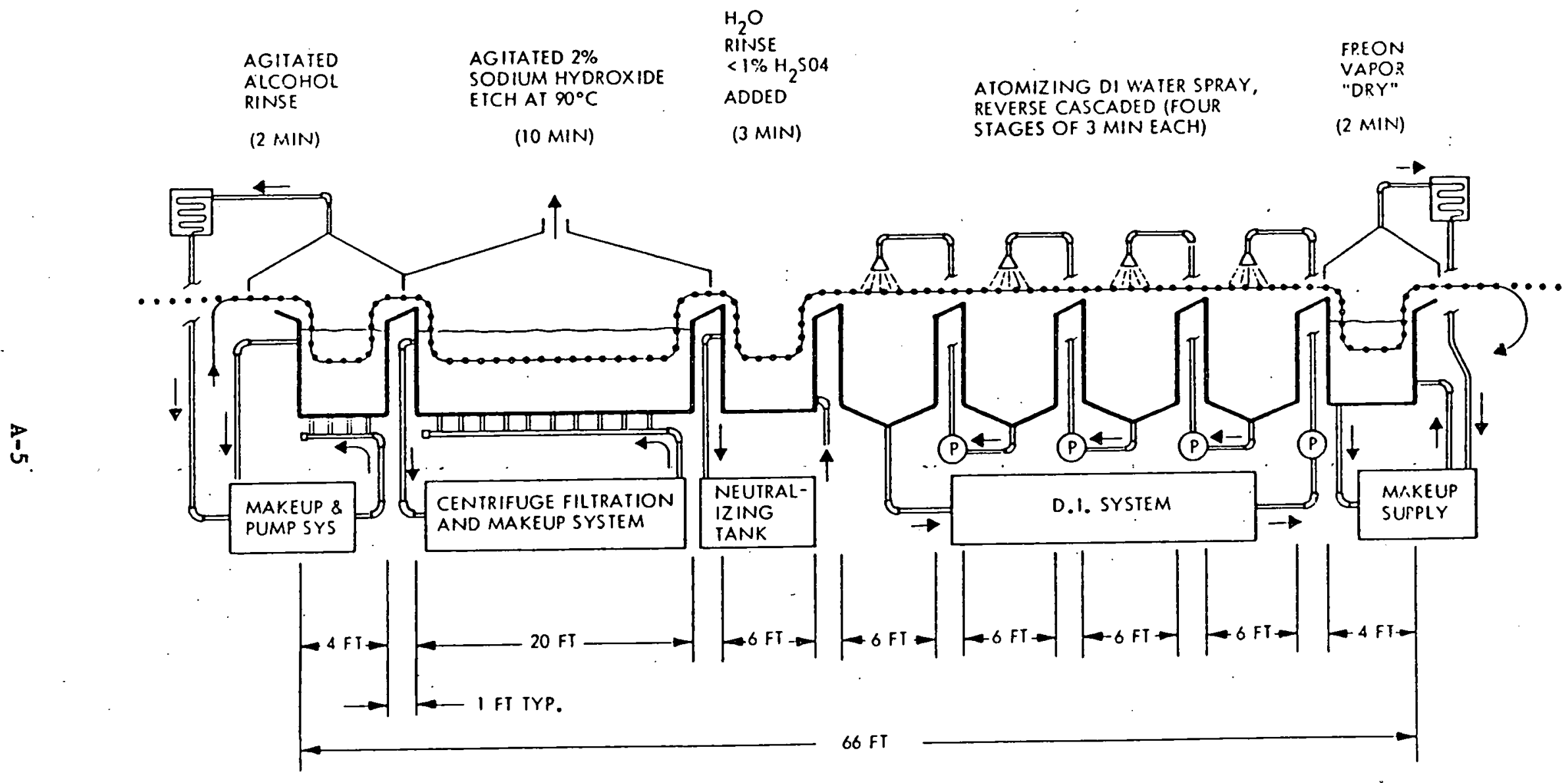

Figure 2. Scliematic - Texture Etch Process 
ing sodium carbonate salts, which are slightly baslc. The next step is a tap water sinse with sufficlent acld added to neutralize the drag-out from etching tank. Ten percent of the outflow is brought to neutral $\mathrm{pH}$ and discarded to control the salt concentration. Makeup acld and water are added to the remalnder which is recirculated. The wafers are then carried through a sertes of four atomizlog spray chambers where they are washed with reverse cascaded DI water. Waste water from the rinse may be used to heat the flrst spray station through a heat exchanger. Thls wash water is also reprocessed through flitration and delonizlog steps. Flnally, the wafers are dried by pasolng through Freon vapor where surface water on the wafers is displaced. As the wafers emerge, the Freon oveporates. Vapors rising into tha hood are recondensed and returmed to the syotem. Displaced water is removed from the Freon to intaln gystem balance. The cassottes are then flxed in an upright posttlon and disengaged from thels holders for transfer to tho aext operation.

The system w111 require computer control to malntain the several varlables. withto pre-established 11mits. Quality of the etch w11l be sensed by test of the reflectivity of wafers leaving the station with automatic corrective action programed. It has been suggested by IR that laser Induced fluorescent spectroscopy may also be employed to check for contamination levels with automatic correction or shutdown procedures incorporated in the control system.

This texture etch station w111 process 4 cassettes or 200 wafers per minute. Four parallel stations will be required. Recycling subsystems will be crossmanifolded between statlons to mialmize downtlme. All tanks will be castored and conflgured for qulck-d1sconnect to allow rapld replacement and offline cleaning and/or refurblshment.

The SAMICS Form $A$ on this proceso is in preparation and will be submitted under separate cover. 
Determined by assumed conveyor speed of texture etch equipment at. $2 \mathrm{ft} / \mathrm{min}$ and spacing of 50 wafer cassettes at 6 " apart.

\section{A-7 Average TIme at Station}

$=38$ minutes

Determined by assumed conveyor speed of texture etch equipment at $2 \mathrm{ft} / \mathrm{min} x$ length of conveyor chain in the proceseing area. $79 \mathrm{ft}+2 \mathrm{ft} / \mathrm{min}$ a $39-1 / 2 \approx 40$ minutes

A-8 Process Usage Time Fraction $\quad .976$

Determined on basis of assumed downtime under the following conditions:

- All tanks fitted with castors and quick disconnect plumbing to allow rapid replacement and off-line cleaning

- Centrifuge filters and other stationary subsystems cross-manifolded to permit rapid changeover, making individual units available for cleaning or service during idle time

- Continuous computer control with feedback loops to eliminate batch operations and allow continuous operation. Downtown assumed to be $4 \mathrm{hrs} / \mathrm{wk}$ for mechantcal maintenance. $24 \mathrm{hrs} /$ day $\times 7$ days $=168 \mathrm{hrs}$

168 hrs -4 hrs downtime $=164$ hrs

164 operating hours $: 168 \mathrm{hrs}=.976$ 
A-9 Component Referent

A-10 Base Price Year for Purchase Price

Selected for availability of recent cost experience

A-11 Purchase Price per Component

Direct estimate from schematic diagram and written description in LMSC Monthly Report No. 6, supplemented by verbal descriptions and prócess notes. Estimate made by LMSC Plant Engineering organization (attached).

A-12 Anticipated Useful Life (Years) = 7

From 5101-33 Interim Price Estimation Guidelines p. 2-1

A-13 Salvage Value \$/Component

$=\$ 30,000$

Arbitrary assumption

A-14 Cost of Removal and Installation

$=\$ 83,000$

Taken at same level as original installation, which is included in A-11 purchase price. Cost of removal is assumed to be offset by reuse of some portion of original installation, e.g., roof penetrations, safety sumps, electrical plumbing, etc. 


\begin{tabular}{|c|c|c|c|}
\hline $\begin{array}{l}\text { A-16 } \\
\text { Catalog Number }\end{array}$ & $\begin{array}{c}A-17 \\
\text { Requirement Description }\end{array}$ & $\begin{array}{c}\text { A-18 } \\
\text { Amt. Req'd. per Machine }\end{array}$ & $\begin{array}{l}\text { A-19 } \\
\text { Units }\end{array}$ \\
\hline$A-2064-D$ & $\begin{array}{c}\text { Manufacturing Space } \\
\end{array}$ & $\begin{array}{l}1000 \\
66^{\prime} \text { length of tank line } \\
\text { plus } 34^{\prime} \text { of service area } \\
=100^{\prime} \text { length total } \\
2^{\prime} \text { width of tanks }+2^{\prime} \text { for } \\
\text { plumbing, etc. }=4^{\prime} \text { plus } \\
\text { clearance for tank removal } \\
\text { at } 6^{\prime}=10 \mathrm{ft} \text { total } \\
100^{\prime} \times 10^{\prime}=1000 \mathrm{sq} \mathrm{ft} .\end{array}$ & $\mathrm{Sq} F \mathrm{t}$ \\
\hline$B-3672-D$ & Chemical Operator II & $\begin{array}{l}2.0 \\
\text { Assumes } 2 \text { operators tending } \\
4 \text { etchant systems }=.5 \\
\text { operator } \times 4 \text { crews }=2.0\end{array}$ & Person/Yrs \\
\hline
\end{tabular}




\section{DIRECT REQUIREMENTS PER BATCH}

\begin{tabular}{|c|c|c|c|c|}
\hline $\begin{array}{r}\text { A-20 } \\
\text { Cata log }\end{array}$ & Number & Requirement Description & $\begin{array}{c}\text { A-22 } \\
\text { Amt. Req'd. per Batch }\end{array}$ & $\begin{array}{l}\text { A-23 } \\
\text { Units }\end{array}$ \\
\hline C1032B & & $\begin{array}{l}\text { Electricity } \\
\text { a. Make up heating of } \\
\text { NaOH sol'n to comp- } \\
\text { ensate for cooling } \\
\text { effect of wafers } \\
\text { b. } \\
\text { Conveyor chain drive } \\
\text { do HP } \\
\text { c. Pumps \& Centrifuges } \\
\text { total } 8 \text { HP for } \\
\text { pumps, } 10 \text { HP for } \\
\text { centrifuges }=18 \text { HP } \\
\text { d. Heating \& Refrig. } \\
\text { units in Freon } \\
\text { tank } \\
\text {. }\end{array}$ & 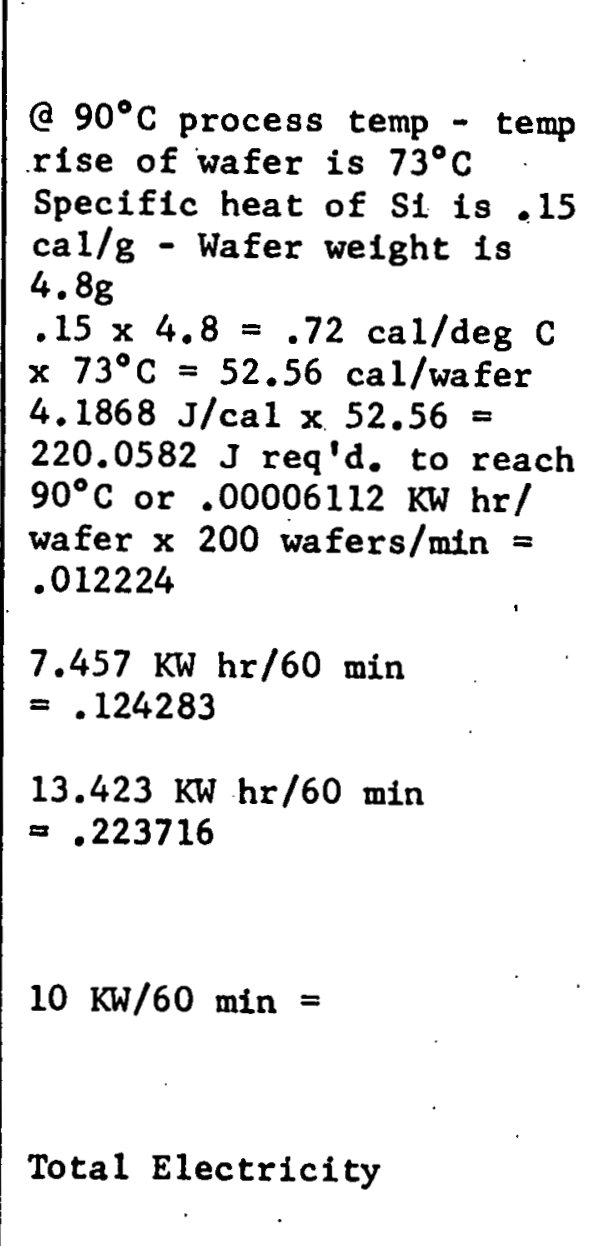 & $\begin{array}{l}.012224 \\
.124283 \\
.223716 \\
.016667 \\
.37689 \\
\mathrm{KW} \mathrm{hr/min}\end{array}$ \\
\hline & & $\begin{array}{l}\text { Alcohol } \\
\text { a. Wafer drag out } \\
\text { b. Filtration \& Misc. } \\
\text { Losses. } \\
\text { A-10 }\end{array}$ & $\begin{array}{l}\text { Drag out @ } .83 \mathrm{~g} / \text { wafer } \\
\text { - (based. on lab tests } \\
\text { w/water alcohol } \\
\text { @ } 3,141.17 \mathrm{~g} / \mathrm{gal} \text { ) } \\
=0002643 \mathrm{gal} / \mathrm{wafer} \\
\times 200 \mathrm{wafers} / \mathrm{min} \\
\text { Estimated @ } 1 \mathrm{gal} / \mathrm{hr} \\
\text { Total Alcohol }\end{array}$ & $\begin{array}{l}.05286 \\
.016667 \\
.069526 \\
\mathrm{Ga} 1 / \mathrm{MIn}\end{array}$ \\
\hline
\end{tabular}




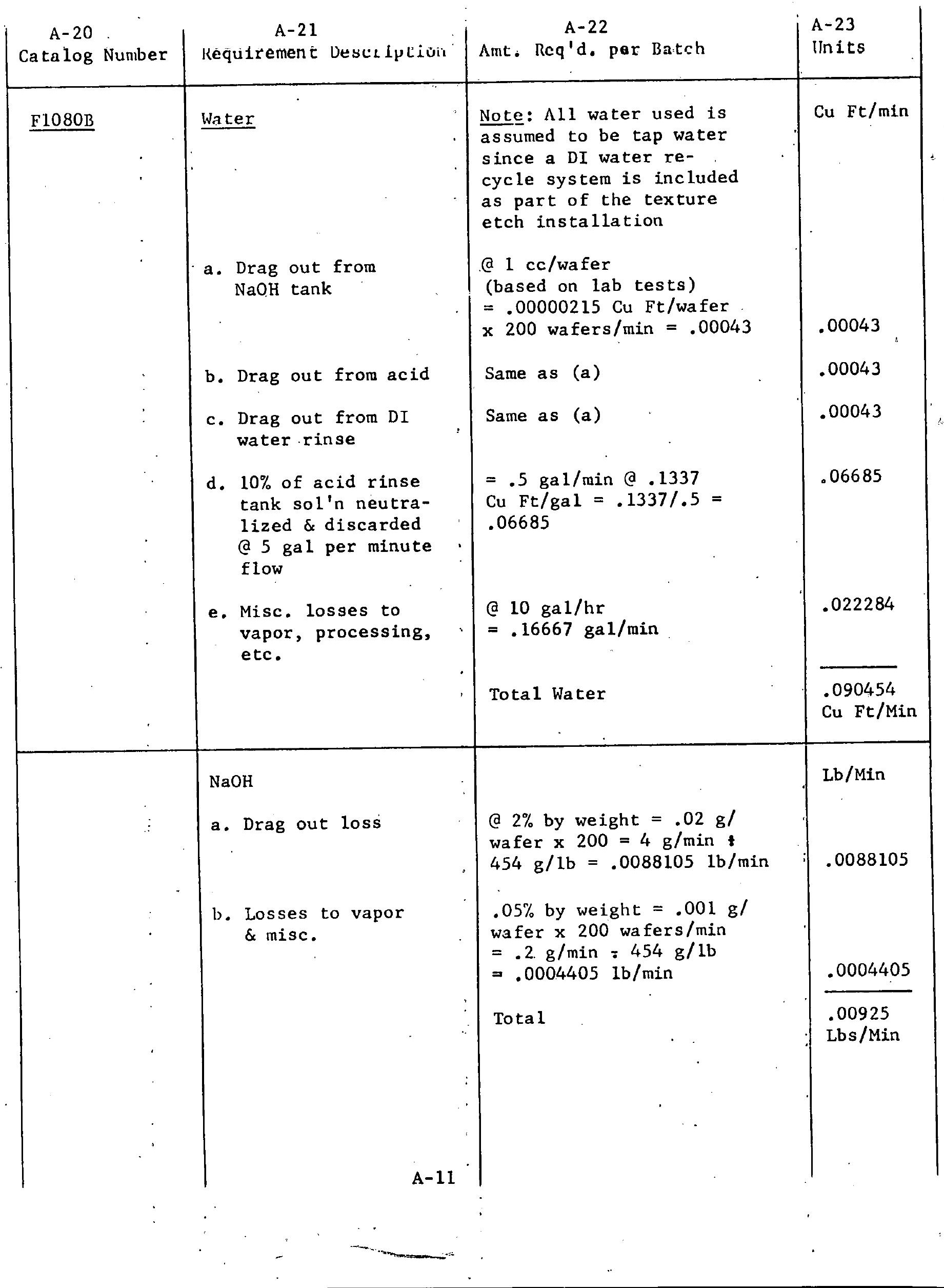




\begin{tabular}{|c|c|c|c|}
\hline $\begin{array}{l}\text { A-20 } \\
\text { Cata log Number }\end{array}$ & Requirement Description & $\begin{array}{c}\text { A-22 } \\
\text { Amt. Req'd. per Batch }\end{array}$ & $\begin{array}{l}\text { A-23 } \\
\text { Units }\end{array}$ \\
\hline " & $\begin{array}{l}\mathrm{H}_{2} \mathrm{SO}_{4} \\
\text { a. Drag out loss } \\
\text { b. Losses to } 10 \% \\
\text { sol'n discard }\end{array}$ & $\begin{array}{l}\text { a } 1 \% \text { by weight }=.019 / \\
\text { wafer } \times 200 \text { wafer/min }= \\
2 \mathrm{~g} / \mathrm{min}: 454 \mathrm{~g} / \mathrm{lb}= \\
.004405 \mathrm{lb} / \mathrm{min} \\
\text { a } 5 \mathrm{gal} \mathrm{sol} \mathrm{n} / \mathrm{min}=.5 \mathrm{gal} \\
\text { discard @ } 10 \% \text { strength }= \\
.05 \mathrm{ga} 1 \mathrm{acid} / \mathrm{min} \\
\text { (@ spec gravity of } 1.86= \\
15.5041 \mathrm{bs} / \mathrm{ga} 1 \text { ) } \\
.05 \times 15.504=.7752 \mathrm{lbs} / \\
\text { min } \\
\text { Total }\end{array}$ & $\begin{array}{l}\text { Lb/Min } \\
.004405 \\
.7752 \\
.779605 \\
\text { Lb/Min }\end{array}$ \\
\hline$\cdot$ & A-12 & e gal/hr $=\underset{\text { ga } 1 / \mathrm{min}}{.016667}$ & $\begin{array}{l}\text { Gal/Min } \\
.016667\end{array}$ \\
\hline
\end{tabular}




\section{SOLAR ARRAY MANUFACTURING INDUSTRY COSTING STANDARDS}

\section{FORMAT A}

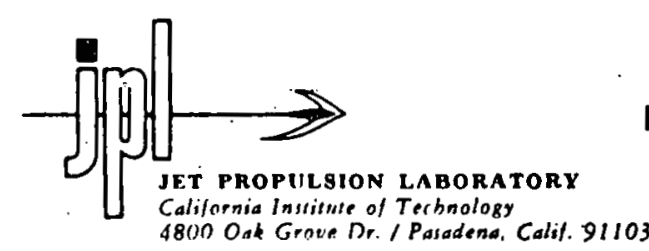

\section{PROCESS DESCRIPTIOON}
A1 Process Referent Ion Plant Revision A, 11-16-78
A2 Description (Optional) Ion Implant phosphorus on face side of wafer

\section{PART 1 - PRODUCT DESCRIPTION}
A3 Product Referent P.I. Wafer
A4 Name or Description Phosphorus ion Implanted wafer

A5 Units Of Measure Wafers

\section{PART 2 - PROCESS CHARACTERISTICS}
A6 Output Rate
50
Units (given on line A5) Per Operating Minute
A7. Average Time at Station
1200
Calendar Minutes
A8 Process Usage Time Fraction
.95
Average Number of Operating Minutes Per Minute

\section{PART 3 - EQUIPMENT COST FACTORS}

A9 Component Referent

N/A

A10 Base Price Year For Purchase Price

1978

A11 Purchase Price (\$ Per Component)

$\$ 500,000$

A12 Anticipated Useful Life (Years)

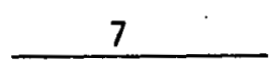

A13 Salvage Value (\$ Per Component)

$\$ 80,000$

A14 Cost of Removal \& Installation (\$/Component)

$\$ 40,000$ 
Format A: Process Description (Continued)

A14 Process Referent (From Page 1)

PART 4 - DIRECT REQUIREMENTS PER MACHINE

A16

Catalog

Number

$A-2064-D$

B-3704-D
A17

Requirement Description

Manufacturing Space

Electron 1cs Technician

Automated Processes

PART 5 - DIRECT REQUIREMENTS PER BATCH (A continuous process has a "batch" of one unit)

A20

Catalog

Number

\begin{tabular}{l}
\hline C1032B \\
\hline$C 1128 D$ \\
$C 2032 D$ \\
$C 1080 D$ \\
\hline
\end{tabular}

E1112D
A21

Requirement Description

Phosphorus Pentafluoride Gas PF5

Electrical Power

Cooling Water

Compressed A1r - 50 ps1

Liquid Nitrogen

Argon
A22

Amount Required

Per Batch

.00555

7

10

.104

.0625

.5

A26

Yield Factor

(Usable Output/Input)

Product Name

Product

Reference

Phosphorus.Ion Implanted Wafer

$99.2 \% *$
A23

Units cc/min

KW hr/hr

$\mathrm{gal} / \mathrm{mln}$

cu $\mathrm{ft} / \mathrm{m} \ln$

11 terg/min

cu $\mathrm{Et} / \mathrm{min}$

TE Wafer Phosphor

Prepared by

R. Cagey

Dațe

* No inspectlon 18 planned at completion of thlo operation Figure representes average yleld for each of seven process steps. REVERSE SIDE JPPL 3037-S 11/77 with final inspection yleld of $95 \%$. 
A-6 Output Rate

Based on calculated scan time for 10 ma beam current with

allowance for spacing between cells on a flat tray - :

A-7 Average Time at Station

1200 Minutes

Based on 16 hours process cycle time per chamber plus two

hours load and two hours unload time per chamber $=20 \mathrm{hrs}$.

A-8 Process Usage Time Fraction

Dependent on filament life which is assumed to be $80 \mathrm{ma} \mathrm{hrs.}$ and w1ll require 20 minutes to change. Filament and chamber replacement to be concurrent. Represents $3.2 \times$ improvement by 1986 in filament life over present Lintott Series III system.

A-9 Component Referent

N/A

A-10 Base Price Year for Purchase Price

Based on current estimate :

A-11 Purchase Price per Component

$\$ 500,000$

(1) Ion Implantation System

$300 \mathrm{~K}$

(5) Cylindrical Chambers a $\$ 20 \mathrm{~K}$ ea. $100 \mathrm{~K}$

(1) Central Implantation Chamber

$40 \mathrm{~K}$

(2000) Trays @ $\$ 30$ ea.

$60 \mathrm{~K}$

Total 500K

A-12 Anticipated Useful Life

7 Years

From 5101-33 Interim Price Estimation Guidelines p. 2-1

A-13 Salvage Val ue

$80 \mathrm{~K}$

Assumes refurbishment possible for vacuum chamber and wafer handling systems

A-14 Cost of Removal and Installation 
ION IMPLANT

FORMAT A

PART 4

Direct Requirements per Machine

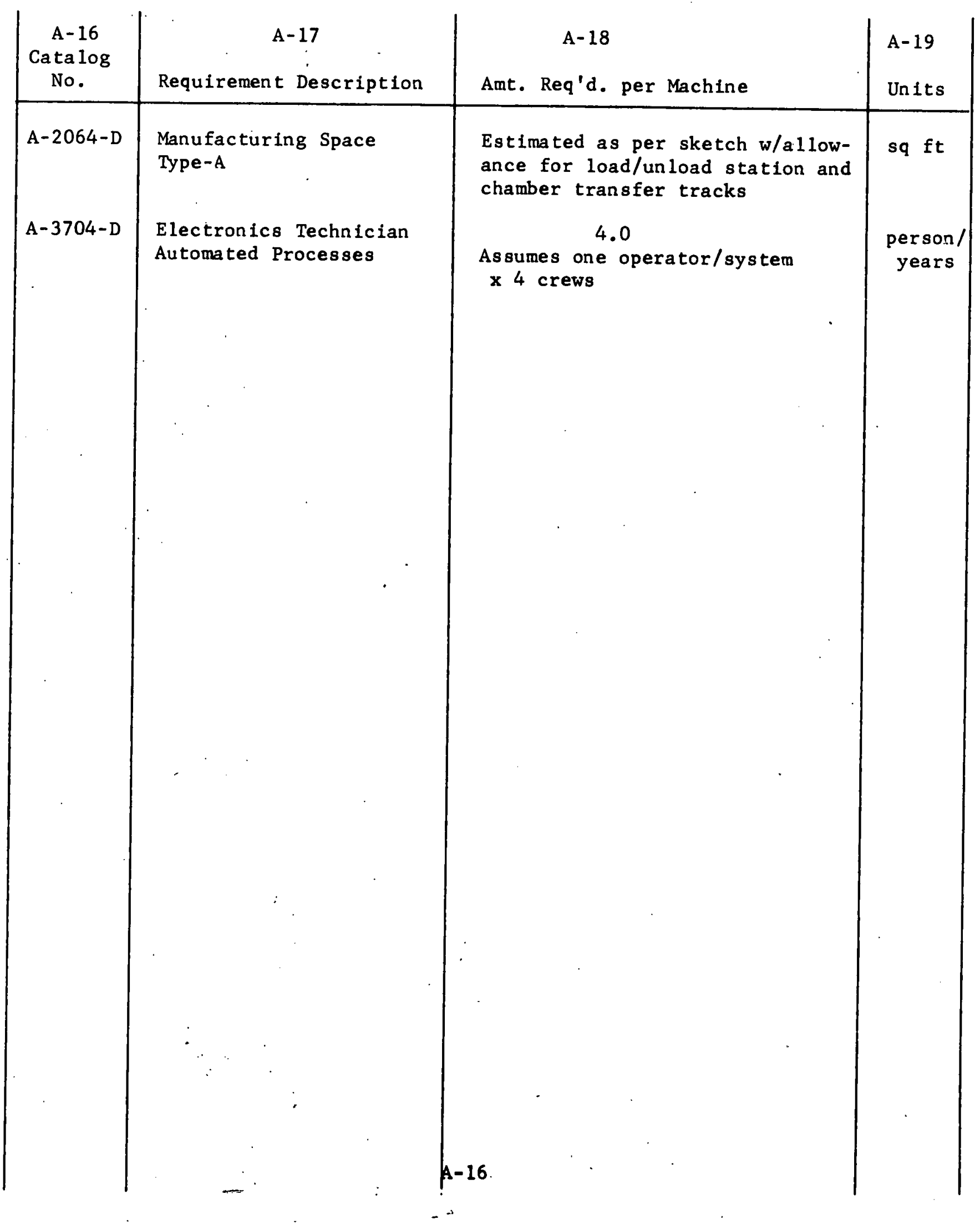


Direct Requirements per Batch Assumed to be a Continuous Process

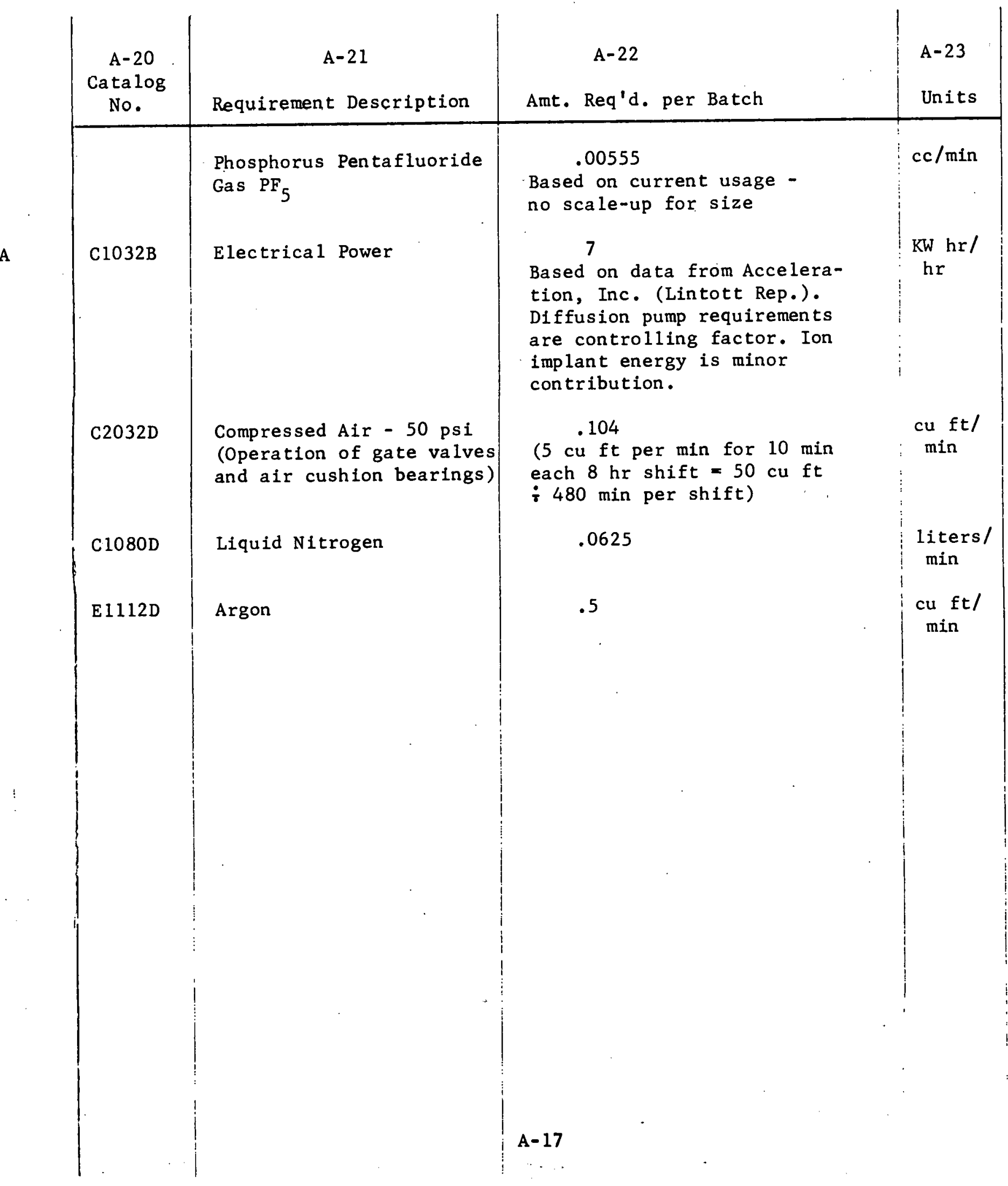


FORMAT A

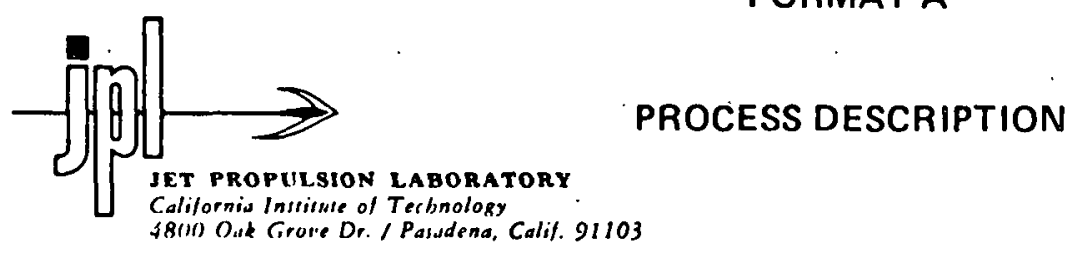
A1 Process Referent LASANNEAL
A2 Description (Optional) Laser Annea 1 Face of Wafer

\section{PART 1 - PRODUCT DESCRIPTION}
A3 Product Referent - L.A. Wafer
A4 Name or Description Laser Annealed Wafer

A5 Units Of Measure Wafers

PART 2 - PROCESS CHARACTERISTICS
A6 Output Rate
60
Units (given on line A5) Per Operating Minute
A7 Average Time at Station
1.0
Calendar Minutes
A8 Process Usage Time Fraction .976
Average Number of Operating Minutes Per Minute

\section{PART 3 - EQUIPMENT COST FACTORS}

A9 Component Referent

A10 Base Price Year For Purchase Price

A11 Purchase Price (\$ Per Component)

A12 Anticipated Useful Life (Years)

A13 Salvage Value (\$ Per Component)

A14 Cost of Removal \& Installation (\$/Component)

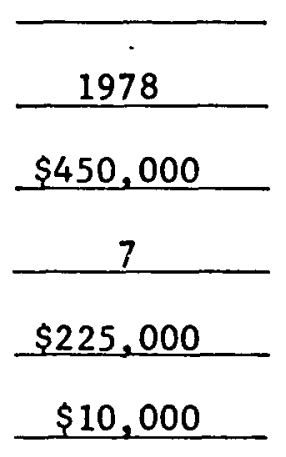

Note: See Appendix to Format A - Laser Anneal for details. 
Format A: Process Description (Continued)

A14 Process Referent (From Page 1)

PART 4 - DIRECT REQUIREMENTS PER MACHINE

A16

Catalog

Number

$\frac{A-2064 D}{B-3704 D}$

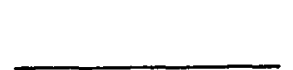

$\overline{-}$

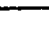

PART

\begin{tabular}{c} 
A20 \\
Catalog \\
Number \\
C $1016 \mathrm{~B}$ \\
\hline C $1032 \mathrm{~B}$ \\
\hline
\end{tabular}

\begin{tabular}{c} 
A21 \\
Requirement Description \\
Tap Water \\
\hline Electricity \\
\hline
\end{tabular}

\begin{tabular}{l} 
Mfg. Space \\
\hline Electronics Technician \\
Automated Processes \\
\hline
\end{tabular}

$\begin{array}{r}200 \\ 2.0 \\ \hline\end{array}$

Amount Required

Per Machine

A19

Units

Sq Ft

Person Years

\begin{tabular}{c} 
A22 \\
$\begin{array}{c}\text { Amount Required } \\
\text { Per Batch }\end{array}$ \\
10 \\
.2268 \\
\hline
\end{tabular}

A23

C

$\mathrm{Ga} 1 / \mathrm{MIn}$

$\mathrm{KW} \mathrm{hr} / \mathrm{min}$

\section{PART 6 - INTRA-INDUSTRY PRODUCT(S) REQUIRED}

\begin{tabular}{cc}
$\begin{array}{c}\text { A24 } \\
\text { Product } \\
\text { Reference }\end{array}$ & A25 \\
I.I. Wafer & Product Name \\
\hline
\end{tabular}
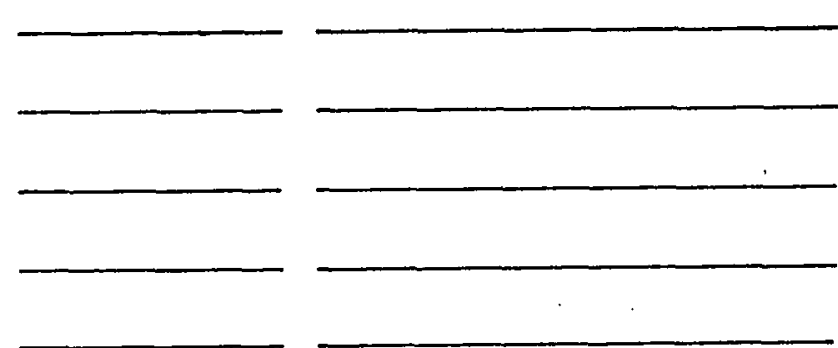

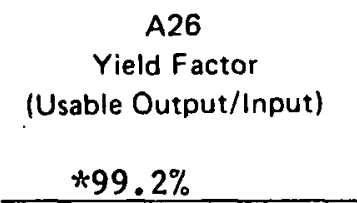

$* 99.2 \%$ 


\section{EQUIPMTNT DESCRIPTION}

\section{Quantel Glass Laser}

This will be a special design unit dedicated to this operation.

Laser energy density of approximately 1.5 joules per $\mathrm{cm}^{2}$ is required to attain annealing of ton implanted silicon wafers. This translates to an energy of approximately 68 joules for a single pulse annealing of a 3-inch diameter wafer. A Q-switched glass laser capable of operating at this energy level with a pulse repetition rate of 1 , pulse per second has a conversion efficiency of approximately . $5 \%$.

\section{Power Requirements:}

68 joules are required to anneal a $3^{\prime \prime}$ diameter wafer. At $.5 \%$ conversion efficiency the laser requires $68 / .005=13,6000$ joules $=3.78$ watt $\mathrm{hr}$

\section{Wafer Transport}

The previous operation in the cell manufacturing sequence is ion implanting from which the wafers are unloaded individually. These will be automatically transferred to a conveyor system which moves the wafers under the laser beam at a constant rate of one wafer per second. At a center to center distance of 4-inches, this represents a conveyor speed of 20 feet per minute. Laser pulse duration is 20 nanoseconds. The laser pulse will be triggered by the wafer passing under the work area. Pulse duration is so short that the wafer need not be stopped for the annealing operation. The conveyor belt will carry the annealed wafers directly to the next operation. 


$$
\begin{aligned}
& \text { A-6 Output Rate } 60 \text { wafers/minute } \\
& \text { Determined by pulse rate of Quantel laser at } 1 \text { pulse per second } \\
& \text { A-7 Average Time at Station }=1.0 \text { minute } \\
& \text { Determined by time on conveyor moving through } 20 \text { foot length of } \\
& \text { station area at rate of } 20 \text { feet per minute }=1 \text { minute } \\
& \text { A-8 Process Usage Time Fraction }=.976 \\
& \text { Arbitrary assumption of } 4 \text { hours per week for maintenance. } \\
& \text { Plant operation taken as } 24 \text { hours/day } x 7 \text { days per week }=168 \text { hours } \\
& 168 \text { hrs }-4 \text { hrs downtime }=164 \text { hours } \\
& 164 \text { operating hours }: 168 \mathrm{hrs}=.976
\end{aligned}
$$




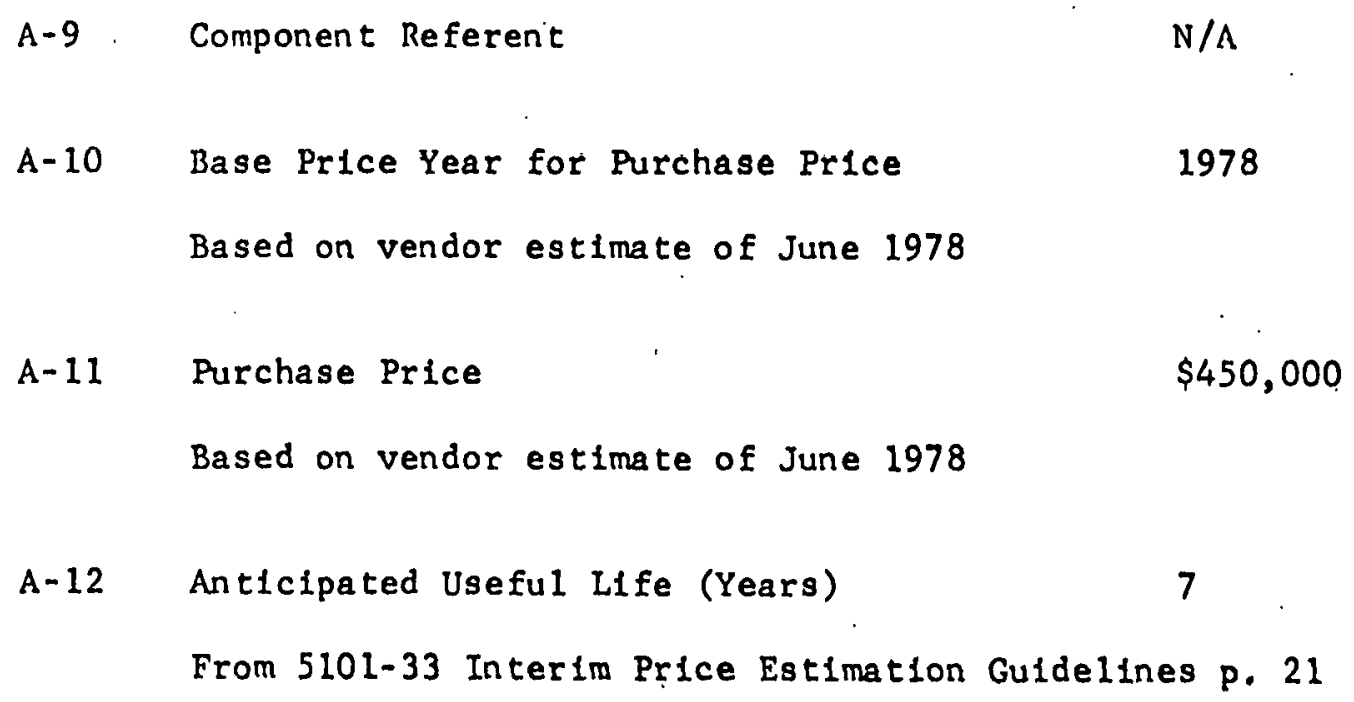

Arbitrary value based on high capabllity for refurblshment and update of equipment.
$A-14$
Cost of Removal and Installation
$\$ 10,000$

Arbltrary cost estimate. Requires only electrical and cooling water hookups. 
DIRECT REQUIREMENTS PER MACHINE

\begin{tabular}{|c|c|c|c|}
\hline $\begin{array}{l}\text { A-16 } \\
\text { Catalog Number }\end{array}$ & Requirement Description & $\begin{array}{l}\Lambda-18 \\
\text { Amt. } \operatorname{Req}{ }^{\prime} d . \text { per Machine }\end{array}$ & $\begin{array}{l}\Lambda \cdot 19 \\
\text { Units }\end{array}$ \\
\hline$A-2064-D$ & Mfg. Space & $\begin{array}{r}200 \\
\left(10^{\prime} \times 20^{\prime}\right)\end{array}$ & $S q F t$ \\
\hline$B-3704-D$ & $\begin{array}{l}\text { Electronics Technician } \\
\text { Automated Processes }\end{array}$ & $\begin{array}{l}2.0 \\
\text { Assumes one operator } \\
\text { tending two machines } \\
.5 \text { operator } \times 4 \text { crews } \\
=2.0 \text { operators }\end{array}$ & $\begin{array}{l}\text { Person/ } \\
\text { Years }\end{array}$ \\
\hline
\end{tabular}

LASER ANNEAL

FORMAT A

PART 5

DIRECT REQUIREMENTS PER BATCH

\begin{tabular}{|c|c|c|c|}
\hline $\begin{array}{l}\text { A-20 } \\
\text { Catalog Number }\end{array}$ & $\frac{A-21}{\text { Requirement Description }}$ & $\begin{array}{c}A-22 \\
\text { Amt. Req'd. per Batch }\end{array}$ & $\begin{array}{l}\text { A-23 } \\
\text { Units }\end{array}$ \\
\hline C $1016 \mathrm{~B}$ & Tap Water & $\begin{array}{c}10 \\
\text { per Equip. Mfr'r } \\
\text { (Quante 1) }\end{array}$ & $\mathrm{Gal} / \mathrm{MIn}$ \\
\hline C $1032 \mathrm{~B}$ & Electricity & $\begin{array}{c}.2268 \\
3.78 \mathrm{~W} \mathrm{hr} / \mathrm{Wafer} \\
\text { @ } 60 \mathrm{wafers} / \mathrm{min} \\
=226.8 \mathrm{~W} \mathrm{hr} / \mathrm{min} \\
\text { or } .2268 \mathrm{~kW} \mathrm{hr} / \mathrm{min}\end{array}$ & $\begin{array}{c}\mathrm{KW} \text { hr/ } \\
\mathrm{min}\end{array}$ \\
\hline
\end{tabular}




\section{SOLAR ARRAY MANUFACTURING INDUSTRY COSTING STANDARDS}

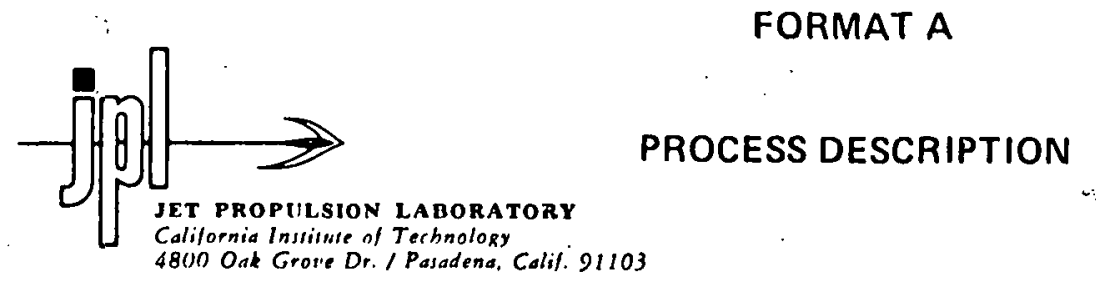

A1 Process Referent Screen

A2 Description (Optional) Screen printing, drying and firing of conductive pastes on back and front sides of wafers

PART 1 - PRODUCT DESCRIPTION

A3 Product Referent SP Wafer

A4 Name or Description Screen Printed Wafers - Both Faces

A5 Units Of Measure

Wa fer

PART 2 - PROCESS CHARACTERISTICS

A6 Output Rate

A7 Average Time at Station

A8 Process Usage Time Fraction
150

2.77 .98
Units (given on line A5) Per Operating Minute

Calendar Minutes

Average Number of Operating Minutes Per Minute

\section{PART 3 - EQUIPMENT COST FACTORS}

A9 Component Referent

A10 Base Price Year For Purchase Price

A11 Purchase Price (\$ Per Component)

A12 Anticipated Useful Life (Years)

A13 Salvage Value (\$ Per-Component)

A14 Cost of Removal \& Installation (\$/Component)

\begin{tabular}{|c|c|c|}
\hline Bk Screen & Ft Screen & Fuse Oven \\
\hline 1978 & 1978 & 1978 \\
\hline 80,000 & 80,000 & 30,000 \\
\hline 7 & 7 & 7 \\
\hline 20,000 & 20,000 & 10,000 \\
\hline 5,000 & 5,000 & 5,000 \\
\hline
\end{tabular}


Format A: Process Description (Continued)

A14 Process Referent (From Page 1 ) Screen

PART 4 - DIRECT REQUIREMENTS PER MACHINE

A16

Catalog

Number

$A-2064-D$

B-3752-D
A17

Requirement Description

Manufacturing Space

Production Machine Operator
A18

Amount Required

Per Machine

500

2
$\mathrm{Sq} . \mathrm{Ft}$.

Person Years

PART 5 - DIRECT REQUIREMENTS PER BATCH (A continuous process has a "batch" of one unit)

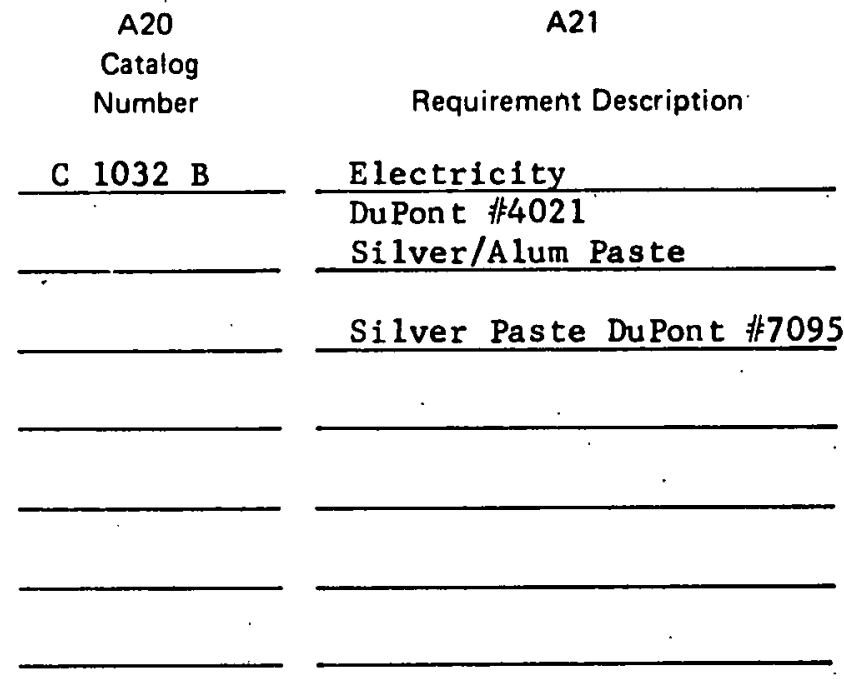

PART 6 - INTRA-INDUSTRY PRODUCT(S) REQUIRED
A22

Amount Required

Per Batch

.29797

115.652

8.096
A23

Units

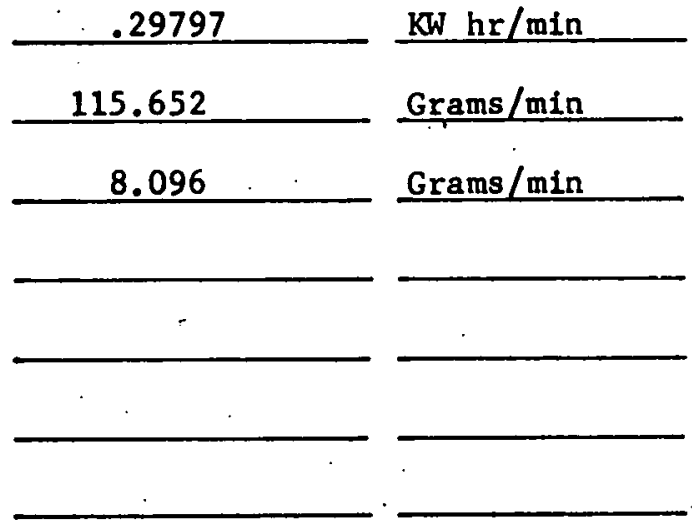

A26

A27

Yield Factor

(Usable Output//nput)

Units

*

Product

Product Name

Laser Annealed Wafer

$* * 99.2$

Sp Wafer/La Wafer

Prepared by R. Casey, LMSC

Date $7 / 26 / 78$

* Laser Annealed Wafer

* No inspection. is planned at completion of this operation. REVERE SIDE JPL. $3037-5$. 11/77 Figure represents average yield for each of 7 process steps with final inspection yield of $95 \%$. 
1500 machine cycles per hour at 6 wafers per cycle processes 9000 wafers per hour $\div 60$ minutes $=150$ wafers per minute. Conveyor speeds for drying ovens and firing oven are paced accordingly.

A-7 Average Time at Station Minutes

Screen printer cycles 25 times per minute producing two rows of 3 wafers each to be transferred to the conveyor. Two rows of wafers at $3.1^{\prime \prime}$ each row $=6.2^{\prime \prime}$ of conveyor length $\times 25$ cycles = conveyor speed of $13 \mathrm{ft} / \mathrm{min}$.

Length of Line:

Turnover and Print Back Face Oven Dry Back Face $\left(30\right.$ sec at $150^{\circ} \mathrm{C}$ )

Turnover and Print Front Face

Oven Dry Front Face ( $30 \mathrm{sec}$. at $150^{\circ} \mathrm{C}$ )

Fuse Conductive Paste $\left(45 \mathrm{sec}\right.$. at $\left.650^{\circ} \mathrm{C}\right)$

Tota 1 Length
6 feet

7 feet

6 feet

7 feet

10 feet

36 feet

$36 \mathrm{ft} . \div 13 \mathrm{ft} / \mathrm{min}=2.77 \mathrm{~min}$ at station

A-8 Process Usage Time Fraction .976

Estimated on basis of 4 hours downtime per 168 hour work week. 
A-11 Purchase Price per Component

Bk Screen $\$ 80,000$

Manufacturers estimate of $\$ 80,000$ for standard unit without cartridge un load and càrtridge reload capability.

Ft Screen $\quad \$ 80,000$

Same as Bk Screen

Fuse Oven $\quad \$ 30,000$

Direct LMSC Estimate

A-12 Useful Life

From 5101-33 Interim Price Estimation Guidelines p. 2-1

A-13 Salvage Valve per Component

Direct LMSC Estimate

A-14 Cost of Removal and Installation

Direct LMSC Estimate 


\begin{tabular}{|c|c|c|c|}
\hline $\begin{array}{l}\text { A- } 16 \\
\text { Catalog No. }\end{array}$ & $\begin{array}{l}\mathrm{A}-17 \\
\text { Requirement Description }\end{array}$ & $\begin{array}{l}\text { A- } 18 \\
\text { Amt Req'd per Machine }\end{array}$ & $\begin{array}{l}\text { A-19 } \\
\text { Units }\end{array}$ \\
\hline$A-2064-D$ & Manufacturing Space & $\begin{array}{l}\quad 500 \mathrm{ft}^{2} \\
36^{\prime} \text { Length of Line } \\
x 10 \text { width }=360 \mathrm{ft}^{2} \\
+140 \mathrm{ft}^{2} \text { service } \\
\text { area }=500 \mathrm{ft}^{2}\end{array}$ & Sq. Ft. \\
\hline$B-3752-D$ & Production Machine Operator & $\begin{array}{l}\quad 2 \\
\text { Assumes one Operator } \\
\text { tending two screen } \\
\text { print systems }=.5 \\
\text { operator } \times 4 \text { crews } \\
=2.0\end{array}$ & Person/Years \\
\hline
\end{tabular}

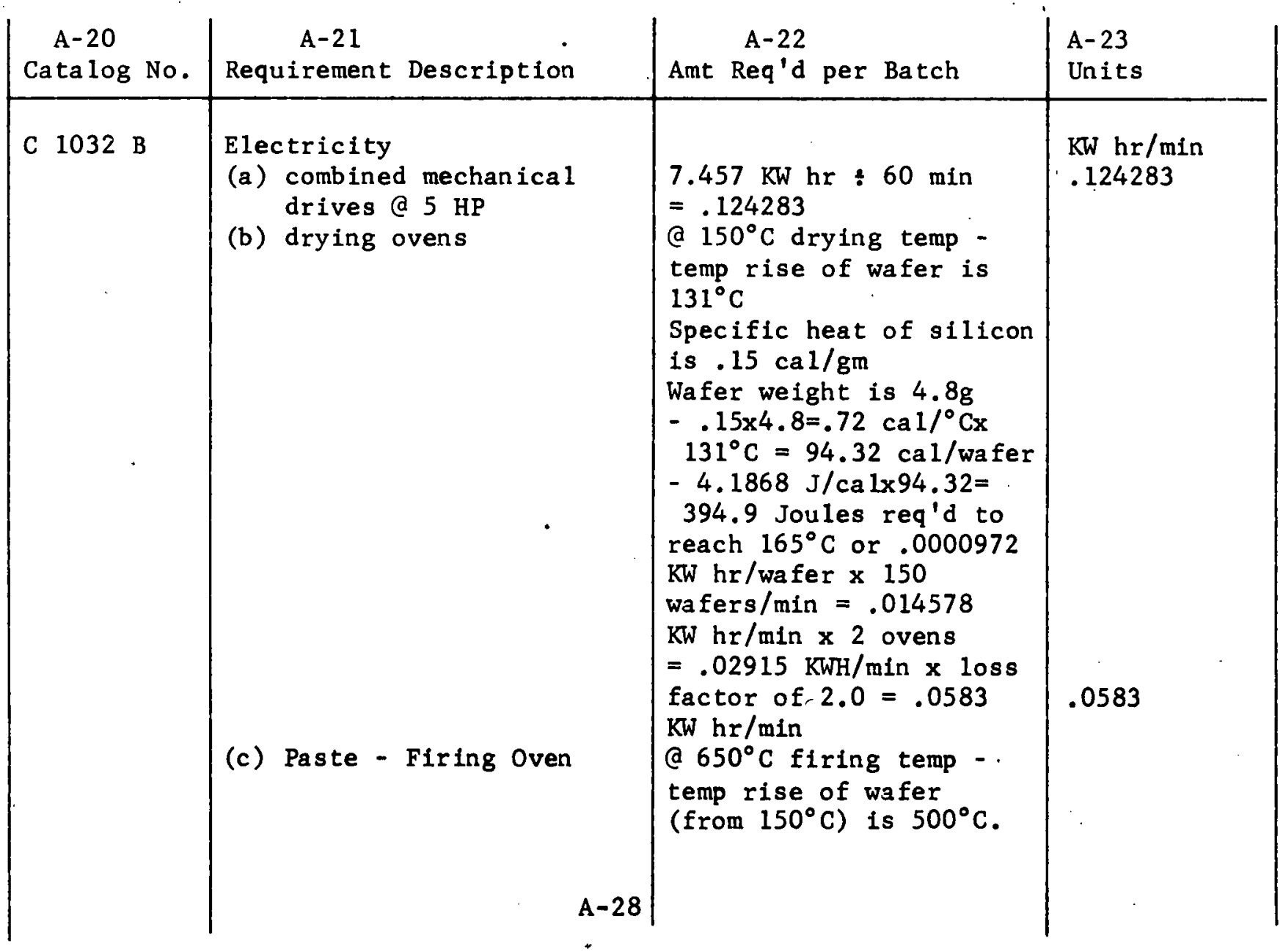


PART 5 - Continued

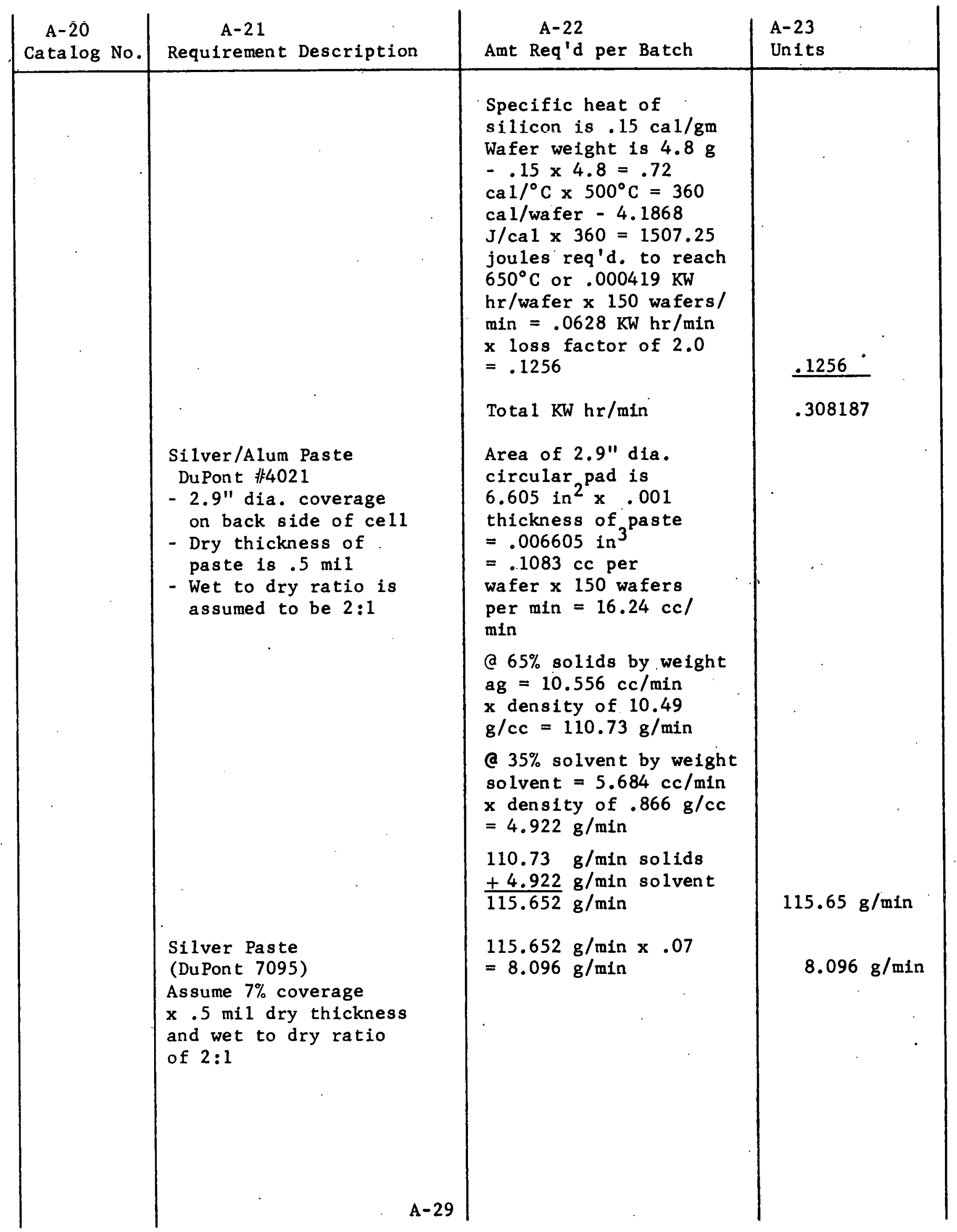




\section{SOLAR ARRAY MANUFACTURING INDUSTRY COSTING STANDARDS}

FORMAT A

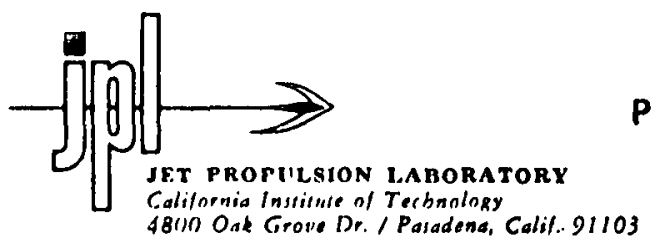

\section{PROCESS DESCRIPTION}
A1 Process Referent AR Coat
A2 Description (Optional) Spray Ant1-Reflect1ve Coating on Wafers

\section{PART 1 - PRODUCT DESCRIPTION}
A3 - Product Referent
AR Wafer
A4 Name nr Description _Ant1-Reflect dye Costed Wafer

A5 Units Of Measure

Wafers

PART 2 - PROCESS CHARACTERISTICS
A6 Output Rate
150
Units (given on line A5) Per Operating Minute
A7 Average Time at Station
9.5
Calendar Minutes
A8 Process Usage Time Fraction .98 Average Number of Operating Minutes Per Minute

PART 3 - EQUIPMENT COST FACTORS

A9 Component Referent

A10 Base Price Year For Purchase Price

A11 Purchase Price (\$ Per Component)

A12 Anticipated Useful Life (Years)

A13 Salvayn Value (\$ Pur Componont)

A14 Cost of Removal \& Installation (\$/Component)

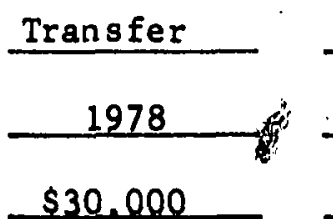

Spray 1978 $\$ 65.000$ 7
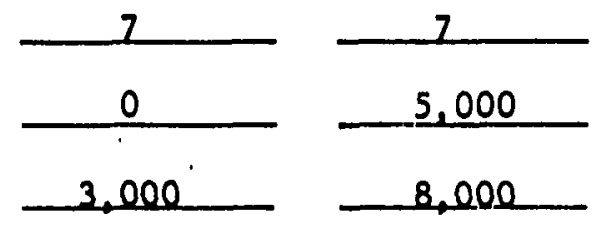
Bake

1978 $\$ 40.000$ 7

5,000 $-8,000$ 
Format A: Process Description (Continued)

A14 Prucéśs Rélèienil (F.u!!" Paye 1) AR. Coat

PART 4 - DIRECT REQUIREMENTS PER MACHINE

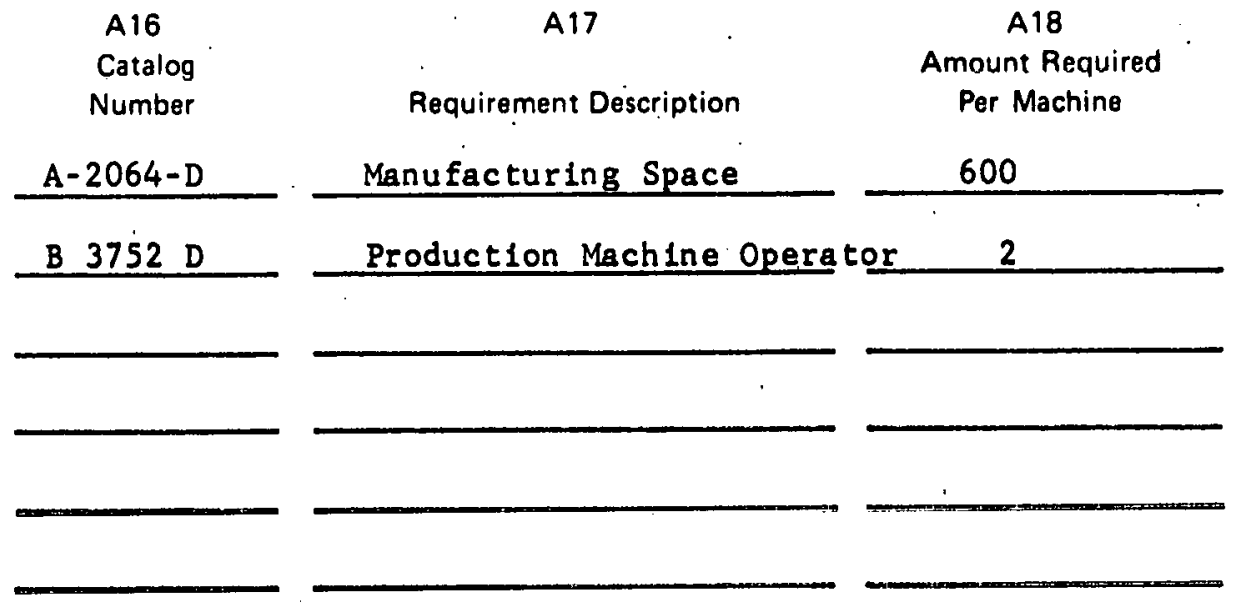

PART 5 - DIRECT REQUIREMENTS PER BATCH (A continuous process has a "batch" of one unit)

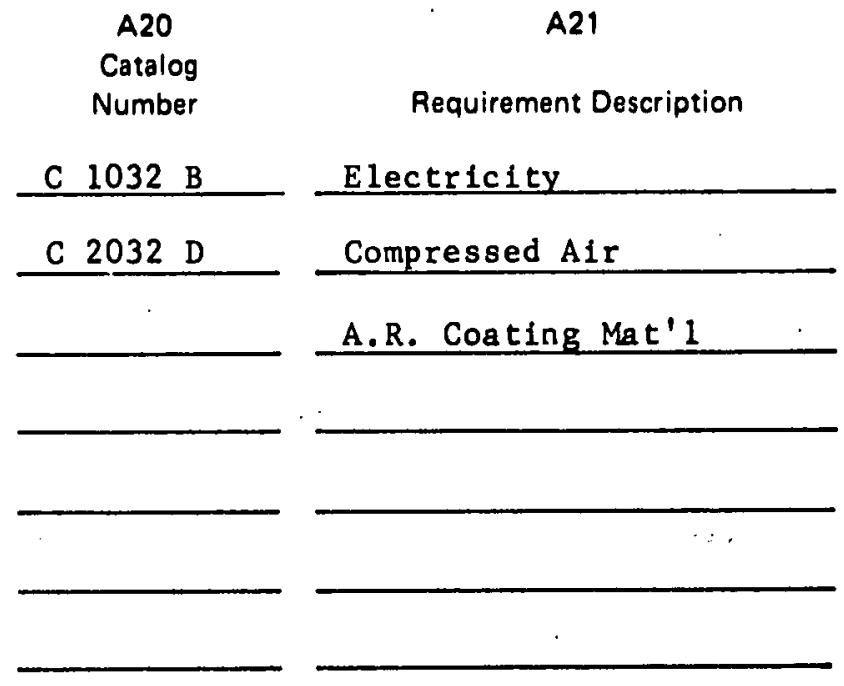

PART 6 - INTRA.INDUSTRY PRODUCT(S) REQUIRED

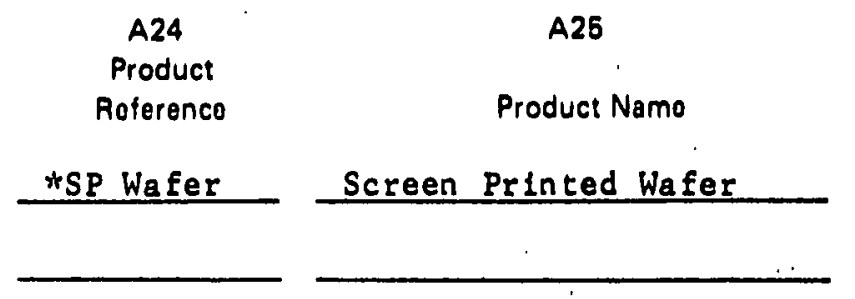

Propared by R. J. Casey, LMSC

* Screen Printed Wafer

* No Inspection is planned at completion of this operation REVERSE SIDE JPL $3037-S$ 11/77 Figure represents average yield for each of seven process steps with final inspection yield of $95 \%$. 
A-6 Output Rate

Production rate matched to prior operation

A-7 Average Time at Station

$9.5 \mathrm{~min}$

Based on conveyor length and speed:

Transfer Device and Spray Booth Conveyor $8 \mathrm{Ft}$

Baking Oven Conveyor

$$
\frac{30 \mathrm{Ft}}{38 \mathrm{Ft}} \text { @ } 4 \mathrm{Ft} / \mathrm{min}=9.5 \mathrm{~min}
$$
A-8 Process Usage Time Fraction
Controlled by preceding screen print operation on
basis of $4 \mathrm{hrs}$. downtime per $168 \mathrm{hr}$. week

.98

ANTI-REFLECTIVE COATING

FORMAT A

PART 3

A-11 thru A-14 A11 items are direct estimates

ANTI-REFLECTIVE COATING

FORMAT A

\begin{tabular}{|c|c|c|c|}
\hline $\begin{array}{l}\text { A- } 16 \\
\text { Catalog No. }\end{array}$ & $\begin{array}{l}\mathrm{A}-17 \\
\text { Requirement Description }\end{array}$ & $\begin{array}{c}A-18 \\
\text { Amt Req'd per Machine }\end{array}$ & $\begin{array}{l}\text { A-19 } \\
\text { Units }\end{array}$ \\
\hline$A-2064-D$ & $\begin{array}{l}\text { Manufacturing Space } \\
\text { Type A }\end{array}$ & $\begin{array}{l}38 \mathrm{ft} \text {. total conveyor } \\
\text { length plus } 12 \mathrm{ft} \\
\text { clearance }=50 \mathrm{ft} \times 12 \\
\mathrm{ft} \text { width including } \\
\text { clearance }=600 \mathrm{sq} . \mathrm{ft} .\end{array}$ & Sq. Ft. \\
\hline$B-3752-D$ & Production Machine Operator & $\begin{array}{l}2 \\
\text { Assumes one operator } \\
\text { tending two coating } \\
\text { systems }=.5 \text { operator } \\
\times 4 \text { crews }=2.0\end{array}$ & Person Years \\
\hline
\end{tabular}

PART 4 


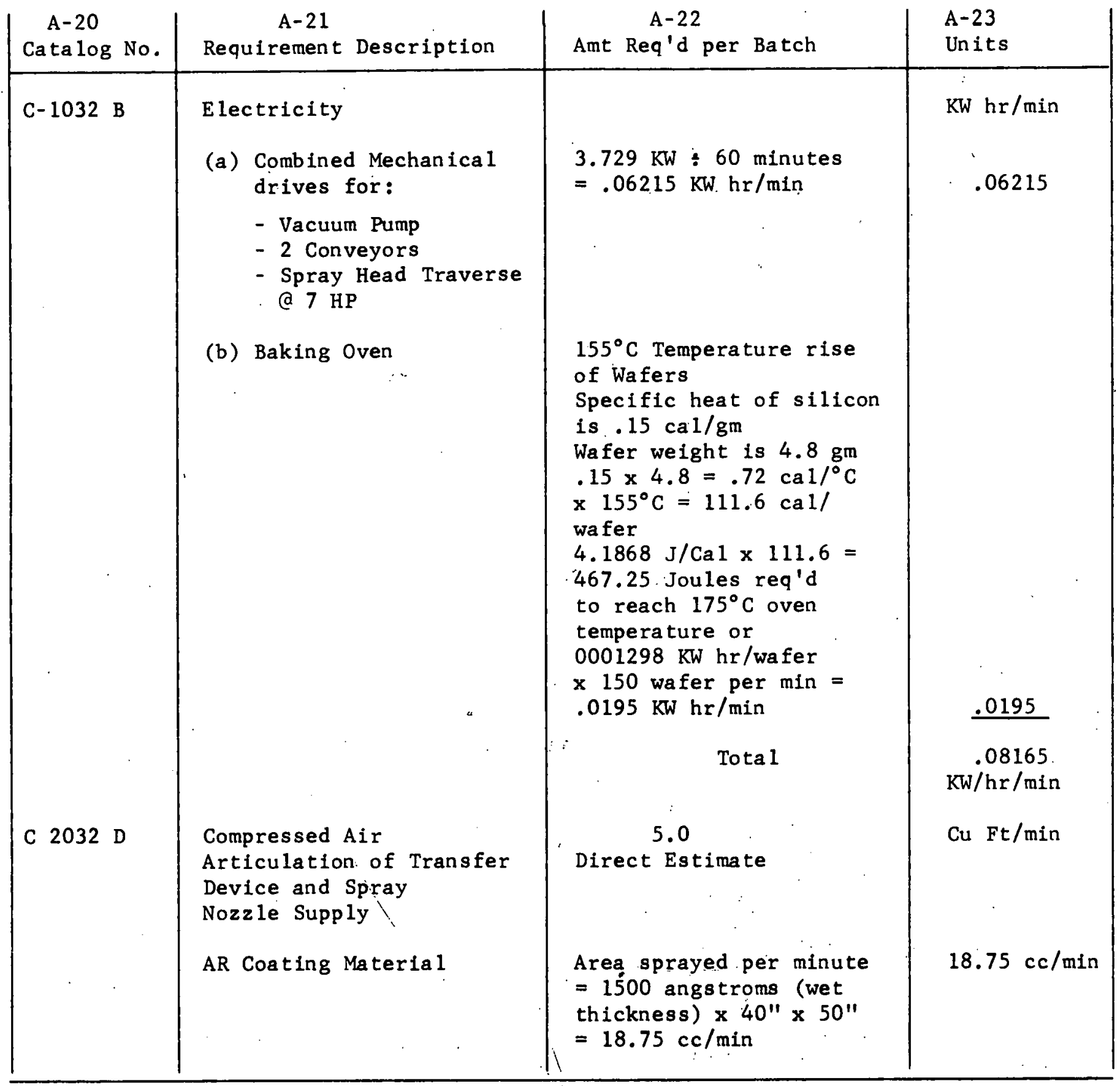

